\title{
STUDIES ON THE BODY-FORMS OF FISHES*
}

\author{
By William K. Gregory
}

(Figs. 117-155 incl.)

\section{OUTLINE}

Part I. The Body-Forms of Fishes and their Inscribed Rectilinear FigurES

Introduction . . . . . . . . . . . . . . . . . . . . . . . 325

The Fish as an Animal Mechanism... . . . . . . . . . . . . . . . 328

The Body-forms of Fishes and their inscribed Rectilinear Figures. . . 334

Constant Factors of Body-Form . . . . . . . . . . . . . . . 342

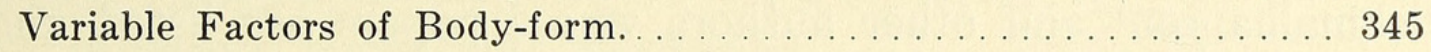

Part II. Preliminary Review of the Evolution of Body-Forms in Fossil AND ReCENT Fishes.

1. Ostracoderms, Cyclostomes and other lowly Chordates........ . 382

2. Elasmobranchs . . . . . . . . . . . . . . . . . . . 388

3. Chondrostei, Holostei and Teleostei................. 396

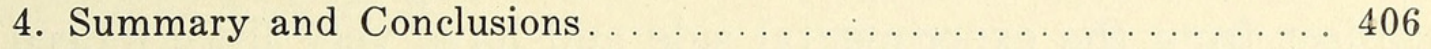

5. Literature consulted . . . . . . . . . . . . . . . . . . . . . . . 413

\section{INTRODUCTION}

The Arcturus Oceanographic Expedition of the New York Zoological Society in 1925 made large collections of deep-sea and pelagic fishes in the Sargasso Sea and in the Central Pacific, and of inshore fishes in the Galapagos Archipelago and Cocos Islands. This collection has provided the material for the present investigation, which deals with the body forms and fins of fishes.

During the expedition the taxonomy, anatomy, osteology and food-habits of the fishes collected were constantly studied by the Director and myself, with the able assistance of Miss Ruth Rose, Miss E. S. Trotter, Mrs. Charles J. Fish and Miss Lillian Segal. The movements and habits of inshore fishes in their native environment were studied by us during many descents in our diving helmets in the Galapagos and Cocos Islands, while pelagic and a few deepsea forms were studied alive in the aquaria on board the ship.

\footnotetext{
* Contribution, New York Zoological Society, Department of Tropical Research, No. 278.
} 
The locomotor apparatus of fishes is inadequately treated even in the best text-books of ichthyology. It is true that these works contain elaborate and detailed morphological descriptions of the parts that compose the locomotor apparatus, but they give little as to its mode of functioning and nothing as to the underlying mechanical and biological principles that condition its construction. Even works that touch upon the subject from the viewpoint of mechanics, such as Marey's Animal Mechanisms, while containing a few valuable facts, do not give a comprehensive picture of the subject as a whole.

On the biological side the clearest general account of the locomotion of fishes which I have been able to find is that by $\mathrm{O}$. Abel in his excellent work, "Grundzüge der Palaeobiologie der Wirbeltiere" (1912, pp. 104-113); but Abel, Dollo, Schlesinger, Whitehouse, Schmalhausen ${ }^{1}$ and other authors whose papers are listed under "Locomotion" in Dean's Bibliography, volume III, have been concerned mainly with the various forms of caudal fins and with such broad categories of body forms as the depressed, the fusiform, the disciform (Abel), the cheloniform (Abel), the tæniiform (Abel) and the sagittiform (Schlesinger). But these papers do not treat the subject from the experimental side and have very little indeed to say about the mechanisms and mechanical reactions involved.

On the experimental side Houssay (1909-1914) has shown very clearly the molding effect of water pressure upon plastic bodies drawn through it at various speeds, these bodies gradually approaching the standard fish type as the experiment was repeated, $\mathrm{He}$ also succeeded in stabilizing the flight of fish-like models by the appropriate placing and tension of artificial fins. Monoyer (1866), Mayer (1886), Duges (1905), and R. C. Osburn (1906) started a very interesting line of work by removing different fins and observing the results on the locomotion of the fish. Their work has been corrected and greatly extended by C. M. Breder, Jr., of the New York Aquarium. He (1926) has attacked the subject from the four converging paths of taxonomy, body form, physiology (adaptation) and physics and has constructed mechanical models to illustrate the modes of locomotion of eel-like and of stiff-bodied fishes.

${ }^{1}$ Schmalhausen's important paper "On the Functions of the Fins of the Fish (Preliminary Note from "Revue Zoologique Russe," not dated) was received in January 1925, after the completion of the present paper. 
It is this synthetic treatment I think, which has brought Breder's long-continued and ingenious experiments to the goal of scientific investigation; for he has repeatedly succeeded, by analysis of the body form and fin characters of a preserved specimen, in inferring with fair degree of accuracy the modes of locomotion of that fish in life.

Before I left New York on the Arcturus expedition Mr. Breder gave me a copy of his then unpublished manuscript on the locomotion of fishes for use in my own studies on the body forms of fishes. The very frequent reference to Mr. Breder's results in the following pages will indicate the extent of my indebtedness to him.

Breder classifies the movements of fishes that progress by lateral undulations under three successive and intergrading classes:

1. The anguilliform type, exemplified in eel-like fishes, with the body elongate, flexible, thrown into a succession of "sine curves," with increasing amplitude posteriorly.

2. The carangiform type, with body movements of intermediate character, to which the vast majority of fishes conform.

3. The ostraciiform, exemplified in the trunk fishes, in which the body itself is rigid and swings from side to side around the peduncle as a fulcrum.

The object of my present and subsequent papers is to supplement Breder's fundamental work by providing a review of the body forms and fins of recent and fossil fishes, with special reference to the proportions and positions of the various parts. The system of describing the body form of fishes with reference to certain partly inscribed rectilinear figures, is apparently new. A search of the literature, at least, has failed to reveal any author to whom I could gladly pay the tribute due to priority.

Ichthyologists have long used the ratios of length and breadth of the different parts of a fish as diagnostic specific characters. In the present studies such ratios and indices will be used, not for this purpose but for the purpose of contrasting and describing the different body forms. With the assistance of Miss Elizabeth S. Trotter, over twelve thousand such measurements, representing over two hundred species of fishes were made in the laboratory of the Arcturus. These measurements will, it is planned, be considered in subsequent papers of this series. 


\section{The Fish as an Animal Mechanism}

The locomotor apparatus: its purpose.-The locomotor apparatus of a fish in obviously one of the chief means by which it plays the game of life, the objects of which are to avoid death, to seek and find life in food and oxygen, to give life to descendants. In order to be successful in these objects, the typical fish must perpetually adjust itself to a highly unstable environment. Wholly sessile animals stay in one spot and let the environment sweep past or through them, while planctonic forms drift about with the currents, but, by means of an elaborate locomotor apparatus, a typical fish navigates with marvellous agility in shifting waters.

The locomotor apparatus and gravity.-The entire locomotor apparatus is therefore orientated primarily with reference to the direction and force of currents of water, which are caused directly or indirectly by the force of gravity, the body form being such as to head upstream with the minimum expenditure of energy necessary to maintain the position of the fish and to prevent it from being swept down stream. Thus the movements of a typical fish, in the long run, are at right angles to the direction of gravity and tangent to the earth's surface. Bilateral symmetry, dorso-ventral differentiation and the elaborate arrangements for maintaining the body in an upright position are accordingly all adjustments to a universal cosmic force. The same universal force also produces pressure in the medium in which the fish lives, and the complex arrangement of wedges, fulcra and levers of a fish's body, relate chiefly to the efficient cleavage of the gravity-pervaded medium. It is for this purpose that energy must be captured from the environment.

Elements of the locomotor machinery. - The striped muscle fibre, which is the unit of the locomotor machinery, is a sort of internal combustion engine. Combustion is effected in every cell of this engine by means of the oxygen which is delivered at the right spot by the hæmoglobin of the blood. The iron in the hæmoglobin, which gives the red color, has the property of taking oxygen from the medium, holding it loosely, without combining with it, and delivering it to the tissues. During this operation the iron itself is not consumed, so that an extremely small quantity may be used again and again. A fish, therefore, like an annelid, a nemertean worm, or a molluse, is an animal that has selected iron for its oxidizing agent. 
A fish has its locomotor engines arranged at right angles to the direction of gravitation, in bilateral symmetry on either side of the mid-line, along which is a more or less jointed stiffening axis, or vertebral column. The controlling and coördinating apparatus or cerebro-spinal nervous system, while arranged segmentally along the body, culminates in a head or central control station at the front end, that is the end towards which the fish moves.

The red muscle fibres of the lateral body muscles are placed more or less horizontally in vertical zig-zag rows, bounded foreand-aft by transverse connective tissue septa. Each muscle fibre is covered by a sheath which is fastened at either end to the zigzag septum. A single zig-zag row is called a myomere or myotome.

First principles of Vertebrate locomotion.-The serially timed contractions of the myomeres on opposite sides bend the body from side to side and cause the lateral undulations which produce a forward movement of the body in the water. Owing to the zigzag arrangement, the myomeres form a vertical series of cones with the apices directed forward. The sharper the angulation of the zig-zag, the further forward the apices of the cones extend, the greater the number of the myomeres in a given transverse plane and the more nearly horizontal is the combined pull of the lateral muscle masses (Greene).

According to Breder (1926) a long-bodied fish starts a wave going backward by jerking the head slightly to one side, through the contraction of some of the myomeres on that side. At the same instant the postcranial part of the body swings still less toward the same side. The whole body then pivots on the head and forms a long sweep ending behind in the tail fin. The body oscillates like a many-jointed pendulum, the forward movement as a whole somewhat resembling the swaying motion of a skater. The bending of the body produces a pressure of water on the posterior side of the backwardly-travelling concavity. In order to secure a forward resultant, however, through the contraction of successive myomeres, the concavities must be passed backward faster than the fish moves forward (Breder). As the concavities are passed backward the amplitude of the undulations along the back bone increases. This gives greater force and a more direct thrust to the posterior end of the body, and demands less lateral movement of the head (Breder). For these and other reasons the greatest cross section of the body is 
always nearer the front end (Parsons); and it is shown below that the entering angle is greater than that of the run.

Coördination and timing of the contractions on opposite sides of the body is probably effected by the crossing over of a portion of the nerve fibres from each segment to the opposite side of the brain.

The fins as accessory locomotor organs.-Median and paired fins are not primary but accessory organs of locomotion, originally used for balancing and steering only. Many lines of evidence support the view that they have arisen, not as continuous folds of skin, but from local projections of the body-wall serving as keels. Thus all fins may be regarded as both fulcra and levers used primarily in balancing and turning various parts of the body, and sometimes (in the more specialized forms) as paddles.

The most primitive fins are those of elasmobranchs, which consist essentially of processes of the body-wall including prolongations of the body muscles, which warp the fin fold. The supporting cartilaginous rods are local stiffenings of the connective tissue septa, occurring in the loci of the greatest stress between opposing muscle sheets. The surface periphery of the fin in elasmobranchs is covered with horny rays (ceratotrichia) which are reduced or lost in the higher fishes. In general, the surface of the fins is less differentiated, more homogeneous in the sharks and their allies than in the typical bony fishes.

The dermal rays of the fins of higher fishes have been derived by a fusion of long ganoid scales and by subsequent emphasis of the bony substratum and reduction of the surface layers, as fully shown in the Palæozoic ganoids of the family Palæoniscidæ. It is also well known that spiny rays were later derived by the fusion of the distal segments or joints of the rays.

The extent to which the fins could be erected or depressed, stretched or relaxed was greatly enhanced by having stiff dermal rays alternate with elastic skin. This umbrella-like arrangement, which is not even foreshadowed in the fins of elasmobranchs, and is but poorly developed in the older ganoids, is one of the basic patents, so to speak, of the later ganoids and typical teleosts. Owing to the extensibility of the fins in these forms, a relatively large fin can be tucked away when not needed, as in straight forward movements, without impeding the movement as it would if it were permanently erected like the dorsal fin of a shark. Again 
it can be suddenly extended when a change of direction or stopping of movement is desired. Consequently the fins of normal-bodied teleosts are generally larger than those of elasmobranchs and their turning and stopping movements are quicker. The later teleosts are thus better able to cope with rapidly shifting currents, and are as a rule, more efficient both in pursuit and in flight. This fact has no doubt contributed materially to the success and dominance of the teleosts in competition with their more conservative relatives of the ganoid group.

The caudal fin.- The shape and position of the fins vary almost infinitely according to the cross sections of the body at different planes and according to the different functions assumed. In general the caudal fin is an active and very adaptable rudder, usually capable of initiating its own series of undulations, in both vertical and horizontal planes. Houssay (1914) has shown that a heterocercal caudal fin also acts as a stabilizer, which prevents the body from rolling over. In very long bodied fishes that swim chiefly by lateral undulations the caudal fin becomes very small or reduced to a point. On the contrary, in very short, stiff bodied forms, such as the trunk fishes, the tail is used in sculling. The tail is excavated posteriorly in swift swimming fishes, because the excavated area is the locus of greatest pressure of the two lateral columns of water that have been displaced by the fish in its forward movement (Nichols). On the other hand, a convex tail, while subject to this pressure, has a firmer fulcrum to push against. A narrow caudal peduncle, joined with a forked or crescentic tail, is found in the carangids, mackerels and other fishes that swim very easily for long distances; again a wide fleshy peduncle and convex tail is found in many fishes that make sudden powerful rushes or leaps.

The dorsal fin.-The dorsal fin is primarily a keel, often erectile and collaborating with the pectorals in maintaining an upright position. The same is true of the anal. When elongated both the dorsal and the anal fins can make their own undulations, which check or modify the various effects of the pectorals and caudals. In deep bodied fishes (such as balistids) the elongate dorsal and anal, opposing each other on the posterior slopes of the body, become important in slow forward movements, and also prevent loss of vertical balance. 
The pectoral fins.-The pectorals are primitively extended in a horizontal plane, as in the sharks, which have relatively broad depressed heads and need strong lateral and vertical keels. Turning is effected by slightly depressing one pectoral and raising the other. In some fishes the pectorals tend to take the initiative over the body muscles, and moderate forward movements are effected by them; as in teuthids, balistids and wrasses.

A subhorizontal position of the pectorals is found in the lower ganoids and teleosts which retain the mesocoracoid arch. These have the pectorals inserted low down near the ventral line. Very early in the history of the teleosts the pectorals acquired the ability to fold back along-side the body during swift forward movements, which they served to check by being suddenly thrust outward. In the higher teleosts the anterior base of the pectoral has been rotated upward so that it lies on the upper border of the fin. Such pectorals are usually inserted higher up on the body and when they are brought forward they oppose a wider surface to the water and are more effective in checking or directing movement. In these cases the mesocoracoid arch is lost (as in the Haplomi and Acanthopterygii) and the base of the fin is nearly vertical instead of horizontal.

In many higher teleosts the water is squirted from the gill slits with such force as to become an important factor in forward locomotion (Breder). In small nervously moving fishes the pectorals keep up a rapid fan-like vibration which may either check the backward thrust from the gill openings or suddenly augment a quick jerk to one side.

The pelvic fins.-The pelvic fins were originally horizontal balancers that served to steady the base of the tail. They are accordingly abdominal in position in the long bodied elasmobranchs as well as in the lower ganoids and teleosts. But the higher teleosts have probably all been derived from short bodied Beryx-like fishes in which the pelvic fins had been shifted forward to a pivotal thoracic position. By tying the pelvic arch on to the base of the pectoral arch the stability of both the pectoral and the pelvic fins was greatly improved and very possibly the lateral sweep of the caudal end of the body could be increased without adding to the length. This combination of the pectoral and pelvic fins no doubt also improved the speed of turning and stopping movements; the 
increased stability of this arrangement very probably made possible an increase in total fin area, as it seems to be a fact that in the average Acanthopterygii the total fin area is greater than in the average Isospondyli and much greater than in the primitive ganoids of the families Palæoniscidæ, Semionotidæ, Eugnathidæ.

The thrusts of the myomeres and fins.- The thrusts of the lateral myomeres are transmitted to the tail through the connective tissue septa, ligaments and tendons as well as by way of the vertebral column. The thrusts of the dorsal fins are not, however, transmitted toward the column. These levers are embedded in a muscle layer, which is tied on to the occiput and has no direct bony connection with the column; the pull of this muscle mass being independent of that of the dorsal muscles of the column. Similarly the anal fin in primitive types is not directly connected with the column, and both dorsal and anal fins have a pulling rather than a pushing effect, their chief office being to pull the anterior end of the body toward the side to which they are deflected. It is only in highly specialized forms, such as balistids and puffers, that the dorsal and anal become paddle-like and tend to push the body forward. Even the tail has a pulling or deflecting effect as well as a pushing movement. In fact the pulling rather than pushing effect probably predominates in all the fins of primitive fishes.

The skull as entering wedge.- The pulling and pushing stresses of all the fins and of the column are transmitted more or less indirectly to the skull, which forms the entering wedge of the body and must withstand the opposing thrusts from the water in front and from the whole muscular body behind. From it are movably suspended and articulated the primary upper and lower jaws, the opercular system, the strong and complex branchial skeleton, the pericardial chamber, and the whole pectoral girdle, which in turn transmits to it the thrusts from the great lateral body muscles; while in its deep recesses the brain, the cranial nerves and the organs of equilibration, feeling, sight and smell find secure lodgement.

The skull is, indeed, a masterpiece of architectural engineering. Its basioccipital forms the base, while the exoccipitals and supraoccipital form the limbs and keystone of a rear transverse arch, while the ossified olfactory capsules and the curved top of the skull form a strong fore-and-aft arch. On the lower side, between the 
orbits, another fore-and-aft arch, or keeled trough, formed by the vomer and parasphenoid bones, ties the forward wedge of the skull to the base of the occiput and forms a chamber for the strong recti muscles that move the eyes. The eyes are placed in a well protected position on either side of the median longitudinal arch and between the massive olfactory capsule in front, and the still larger brain-case behind.

Entrance and run.-In conclusion the locomotor apparatus of a fish may be conceived as consisting of two overlapping parts, conforming, as a whole, to stream-line requirements:

1. An entrance, or wedge-like portion, the passive part of the mechanism, comprising the head, throat and abdomen, and thus including: (a) the skull, enclosing the automatic control or navigating mechanism, (central nervous system, sense organs); (b) the circulatory or fuel-distributing system; (c) the respiratory or oxygenating and oxidizing system, and its skeletal supports; (d) the ingestive or fuel-securing apparatus (including the primary and secondary upper and lower jaws and their dentition); (e) the digestive or fuelpreparing apparatus (the digestive tract and its glands); (f) the reproductive system; the whole being surrounded by an insulating or protecting cover of skin, scales, surface bones etc.

2. The run, or sloping surface behind the greatest cross-section of the body, a smooth, flexible covering, enveloping the abdomen, back sides, and fins, forming the surface along which the displaced water flows backward.

The propelling apparatus is located chiefly in the run. It includes the muscular substratum of the run, the connective tissue septa, the ribs, the backbone and its apophyses, the fins and their supports and the whole caudal part of the body.

\section{The Body-Forms of Fishes and Their Inscribed Rectilinear Figures}

The body forms of normal fishes in the lateral view have certain relations to quadrilateral figures of varying proportions that may be inscribed within them. The anatomically constant points of reference and axes of these figures may be named as follows:

1. prosthion $(P)$ : the most anterior point of the snout (or of either jaw when the latter protrudes beyond the snout).

2. pygidion $(p)$ : the mid-point of the caudal peduncle. The line 

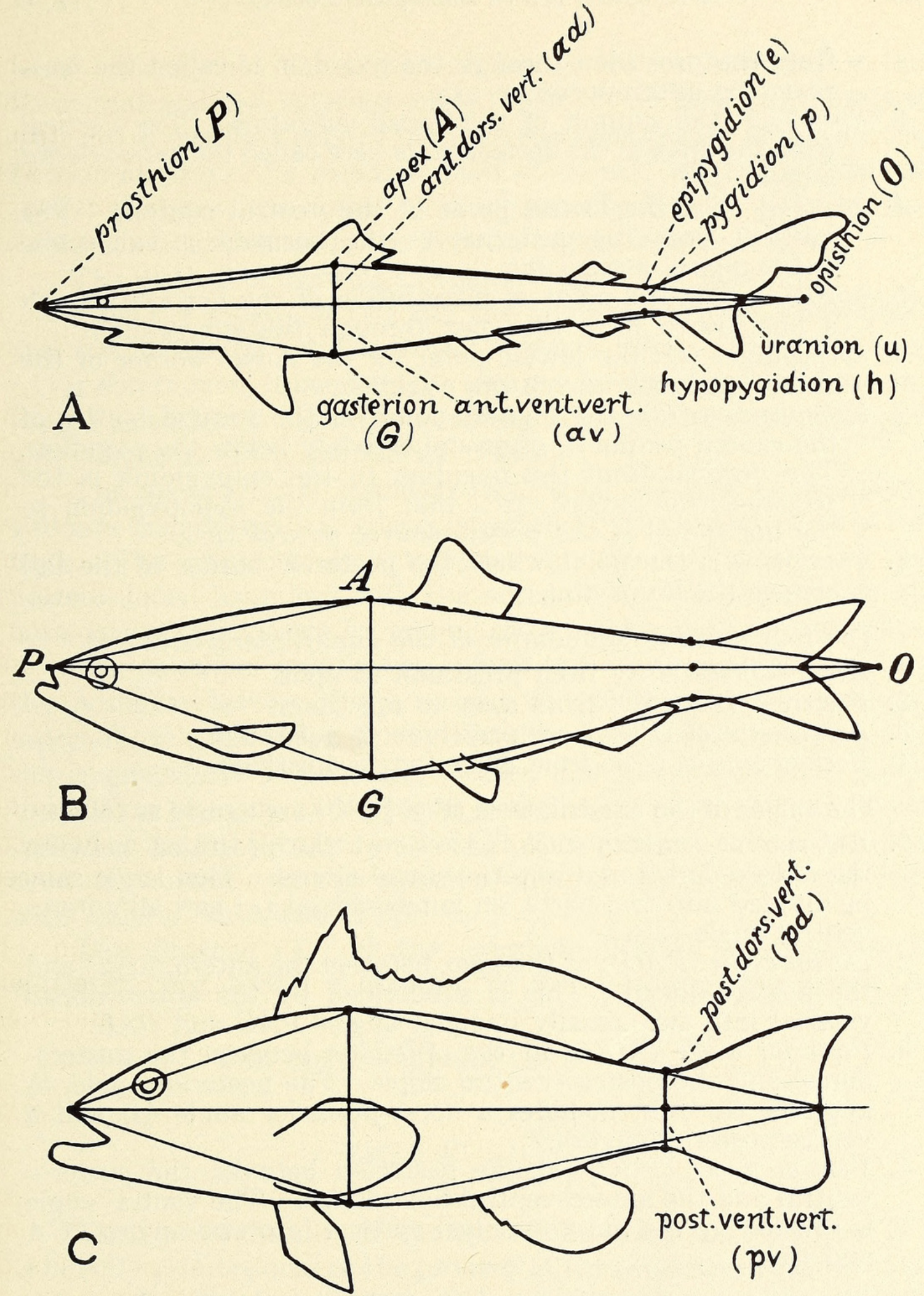

Fig. 117. The body-forms and fins of typical fishes, in their relations to quadrilateral figures. A, Shark (Catulus uter); B, Herring (Clupea harengus); C, Serranid (Paralabrax maculatofasciatus). Outlines after Jordan and Evermann. 
from the prosthion through the pygidion is called the horizontal or anteroposterior axis.

3. apex $(A)$ : the summit of the dorsal curvature. The vertical from the apex to the horizontal is here called the antero-dorsal vertical $(a d)$.

4. gasterion $(G)$ : the lowest point of the ventral contour. The vertical from the gasterion to the horizont is called the antero-ventral vertical (av).

5. opisthion $(O)$ : the point of intersection of the horizontal with a line drawn from the apex through the epipygidion.

6. epipygidion $(e)$ : the lowest point on the dorsal border of the caudal peduncle above the pygidion.

7. hypopygidion $(h)$ : the highest point on the ventral border of the caudal peduncle, often immediately below the pygidion. The vertical from the pygidion to the epipygidion is the postero-dorsal vertical ( $p d)$; that from the hypopygidion to the horizontal is the postero-ventral vertical $(p v)$.

8. uranion $(u)$ : the point where the posterior border of the tail crosses the horizontal.

The four sides or boundaries of the quadrilateral are:

1. Antero-dorsal (PA) from prosthion to apex.

2. Postero-dorsal $(A O)$ from apex to opisthion.

3. Antero-ventral $(P G)$ from prosthion to gasterion.

4. Postero-ventral $(G O)$ from gasterion to opisthion.

The angles of the quadrilateral (Fig. 118C) are named as follows:

1. Anterior or entering angle $(A P G)$ : at the prosthion between the antero-dorsal and antero-ventral slopes. This angle may be divided into two parts, an antero-dorsal $(a)$ and an anteroventral angle $\left(a^{\prime}\right)$.

2. Dorsal angle $(P A O)$ : at the apex between the antero-dorsal and the postero-dorsal. This is subdivided by the antero-dorsal vertical into two usually unequal angles $P A G$ and $O A G$.

3. Posterior angle $(A O G)$ : at the opisthion between the posterodorsal and the postero-ventral slope. The posterior angle, or angle of the run, includes a dorso-posterior angle $(\beta)$ and a ventro-posterior angle $\left(\beta^{\prime}\right)$.

4. Ventral angle $(P G O)$ : at the gasterion between the posteroventral and the antero-ventral boundaries. The ventral angle is divided by the antero-ventral vertical into two angles $P G A$ and $O G A$.

When the dorsal vertical and ventral vertical are in line with each other the single vertical diameter divides the quadrilateral into two acute-angled triangles, one pointing forward $(A P G)$, the other backward $(A O G)$, the vertical diameter being the common 
base. Usually the dorsal vertical lies in the anterior half of the horizontal and the entering angle (apex of the forwardly directed triangle) is therefore greater than the posterior angle. Similarly the horizontal forms the common base of dorsal (APO) and ventral $(P G O)$ triangles, the apices of which usually become more obtuse as the horizontal exceeds the vertical or verticals in length.

The method of drawing the quadrilateral is as follows:

First the prosthion $(P)$ and the pygidion $(p)$ are determined and the horizontal $(P p)$ is drawn through them. Then the apex $(A)$ is determined, it being at the greatest height above the horizontal. The gasterion $(G)$ is then fixed and the antero-dorsal $(P A)$ and antero-ventral $(P G)$ boundaries drawn.

The postero-dorsal boundary $(A O)$ from the apex to the epipygidion is then drawn. It is usually tangent to the general slope of the back. The opisthion is determined by the intersection of the postero-dorsal boundary with the horizontal. The postero-ventral boundary is then drawn by joining the opisthion with the gasterion.

The opisthion usually lies behind the uranion, or point where the posterior border of the caudal fin intersects the horizontal, especially in large-tailed fishes. In this case, the posterior part of the quadrilateral lies entirely behind the body contour. When the body is elongate and tapering posteriorly and when the vertical spread of the tail becomes very small, the opisthion and the uranion tend to coincide and the posterior contour of the body coincides with that of the quadrilateral.

The distance $\left(X^{\prime}\right)$ of the opisthion behind the pygidion is evidently (Fig. 118D) a function of the dorso-posterior angle $(\beta)$

$$
\begin{gathered}
\text { Now } \tan \beta=\frac{p d}{X^{\prime}} \text { and } \tan \beta^{\prime}=\frac{a d-p d}{X} ; \\
\text { hence } X^{\prime}=\frac{X p d}{a d-p d}
\end{gathered}
$$

That is the distance of the opisthion behind the pygidion $\left(X^{\prime}\right)$ is directly proportional to the product of the posterior dorsal vertical $(p d)$ by the distance between the anterior and posterior verticals $(X)$; and, inversely proportional to the difference between the antero-dorsal and postero-dorsal verticals. As the difference between the antero-dorsal and postero-dorsal verticals becomes 


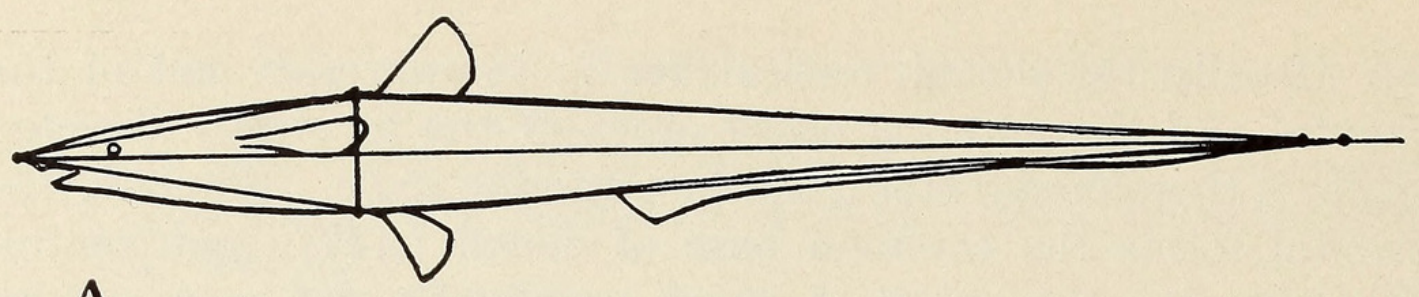

A
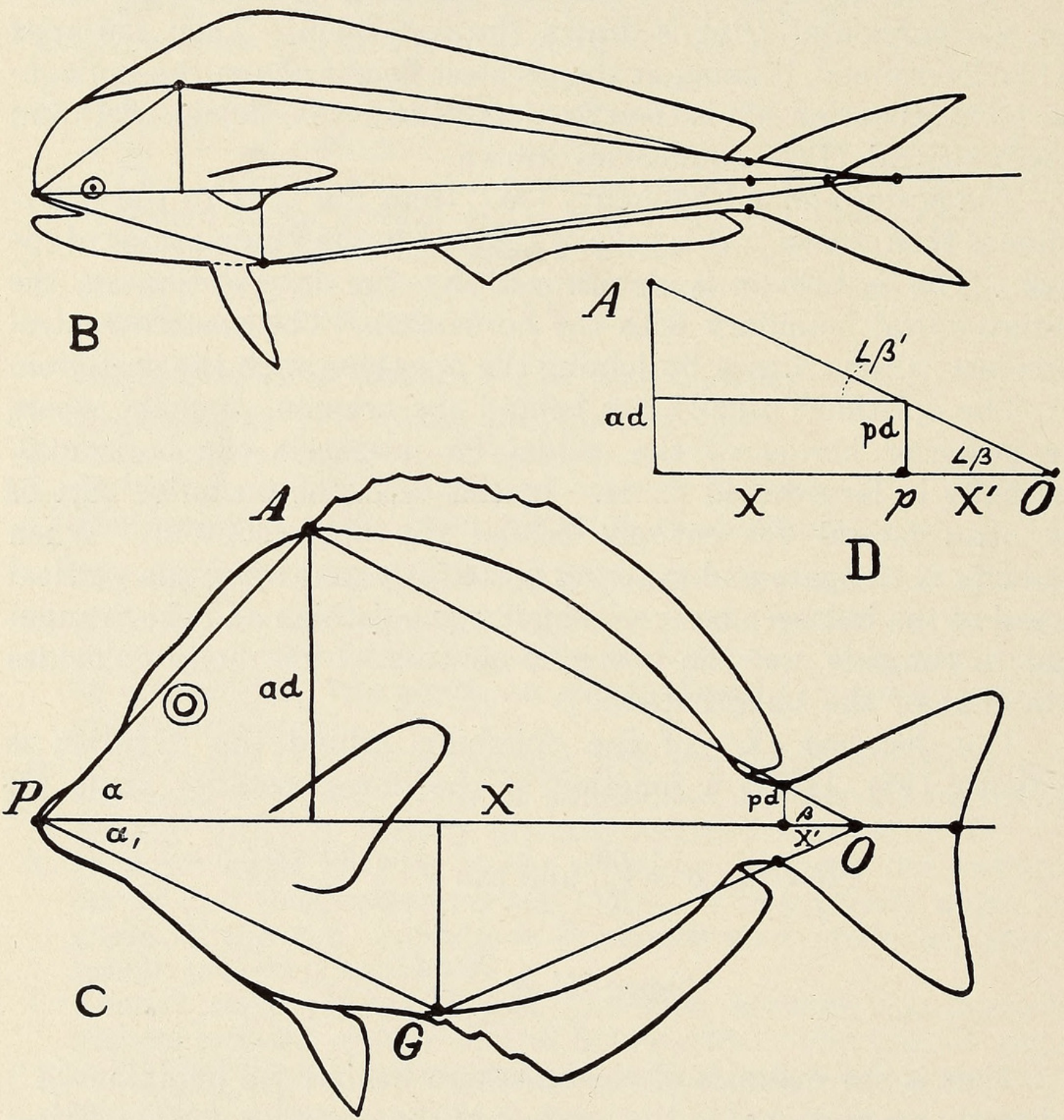

Fig. 118. The body-forms and fins of specialized fishes. A, Deep-sea fish, Aldrovandia macrochir; B, Dolphin (Coryphæna hippurus); C, Surgeon fish (Xesurus punctatus); D, Geometric relations of the opisthion (o) and pygidion $(p)$ of the anterior and posterior dorsal verticals (ad, pd). Outlines after Jordan and Evermann. 
smaller, compared to the distance between them, the opisthion moves backward toward infinity. (Fig. 119B.) Again, if $X$ be relatively great $X^{\prime}$ will also be large, as in certain Percidæ (Fig. 149A).
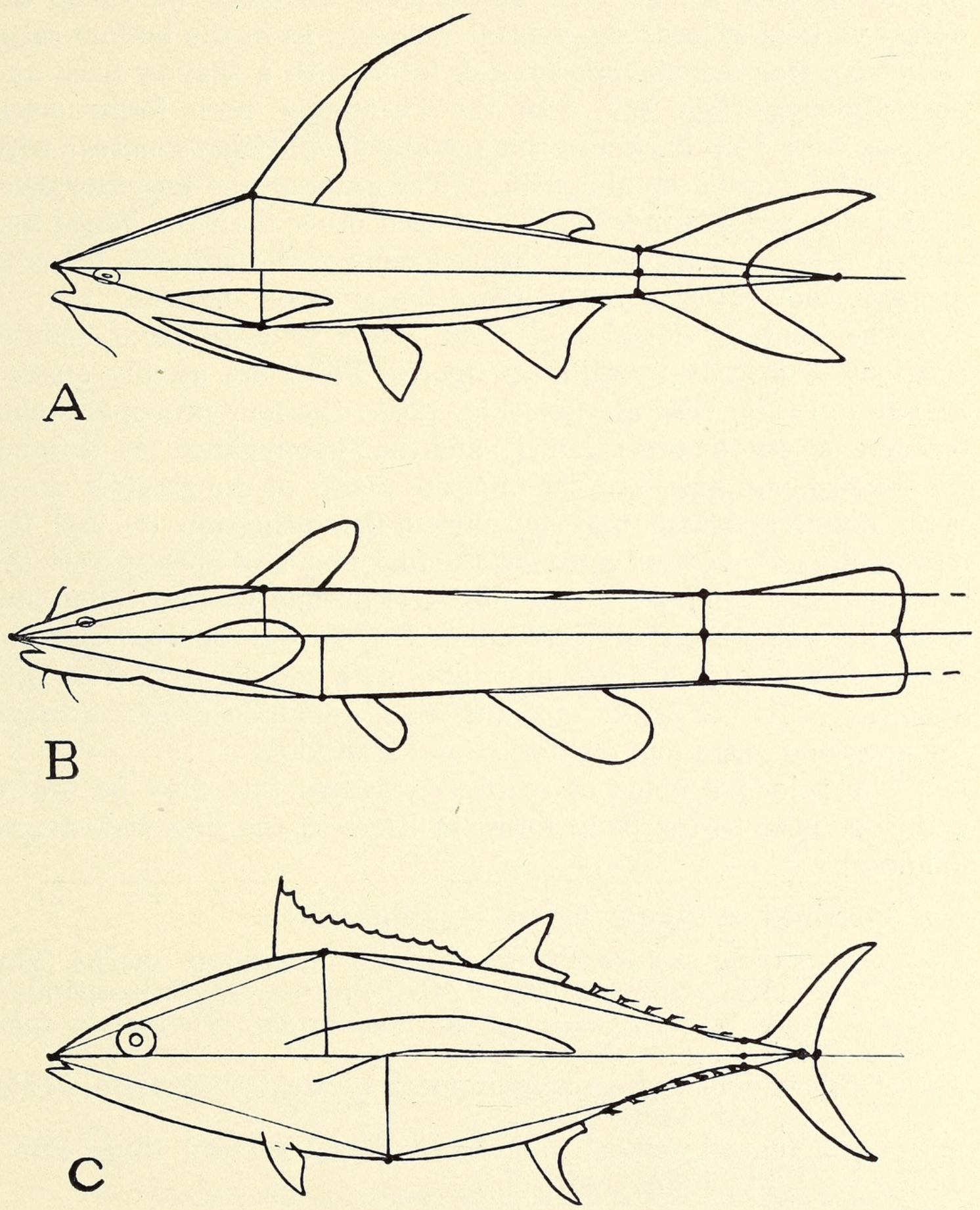

Fig. 119. Varying relations of the opisthion to the uranion. A, Opisthion posturanic (Felichthys marinus); B, Opisthion posturanic approaching infinity (Schilbeodes insignis); C, Opisthion preuranic (Germo alalunga). Outlines after Jordan and Evermann. 
The horizontal divides the body-form into upper and lower moieties, which in different series of related genera appear to have some degree of independence of each other. Thus starting from normal forms with subequal dorsal and ventral moieties we may find forms with a high back and shallow abdomen (in which the dorsal vertical exceeds the ventral vertical), as in the buffalo carps (Ictiobus), Haemulidae, Sparidae, or forms with a shallow back and deep abdomen (Fig. 127). In the Carangidæ both forms occur (Selene, with deep back and shallow abdomen, Chloroscombrus with shallow back and deep abdomen). The anterior and posterior pairs of triangles are less independent of each other than the dorsal and ventral sets, since a forward displacement of the verticals tends to decrease the posterior and increase the anterior angles.

The ventral, dorsal and front views likewise have definite relations to inscribed rectilinear figures, which are usually quadrilaterals. In the ventral view (Fig. 120A) the four principal points of reference are the prosthion $(P)$ and the hypopygidion $(h)$, defining the longitudinal axis, and the opposite points of the greatest transverse diameter which may be named the dexiterion $(\delta)$ and the aristerion $(a)$. In the front view the four points of reference are the prosthion and the apex, fixing the vertical, and the dexiterion and aristerion fixing the transverse diameter. In the top view the four points of reference are the prosthion, epipygidion, dexiterion and aristerion. In the back view the axes would be drawn through the apex and gasterion, dexiterion and aristerion.

The principal kinds of rectilinear figures that may be drawn within or near to the body forms of fishes in the side view are as follows:

1. Inscribed rectilinear figures quadrilateral:

(a) Dorsal and ventral verticals in line: many sharks (Fig. 117A), sturgeons (Fig. 124B), Protospondyli, Isospondyli (Fig. 117B), Ostariophysi, Scombridæ, Micropterus dolomieu, etc.

(b) Ventral vertical behind dorsal vertical (Figs. 125A, 118B, C, 121, 126B, D).

(c) Ventral vertical in front of dorsal vertical (Figs. 125C, 122B, 138A, 148B, C).

2. Inscribed rectilinear figure pentagonal.

When the ventral fins are shifted forward below the pectorals 

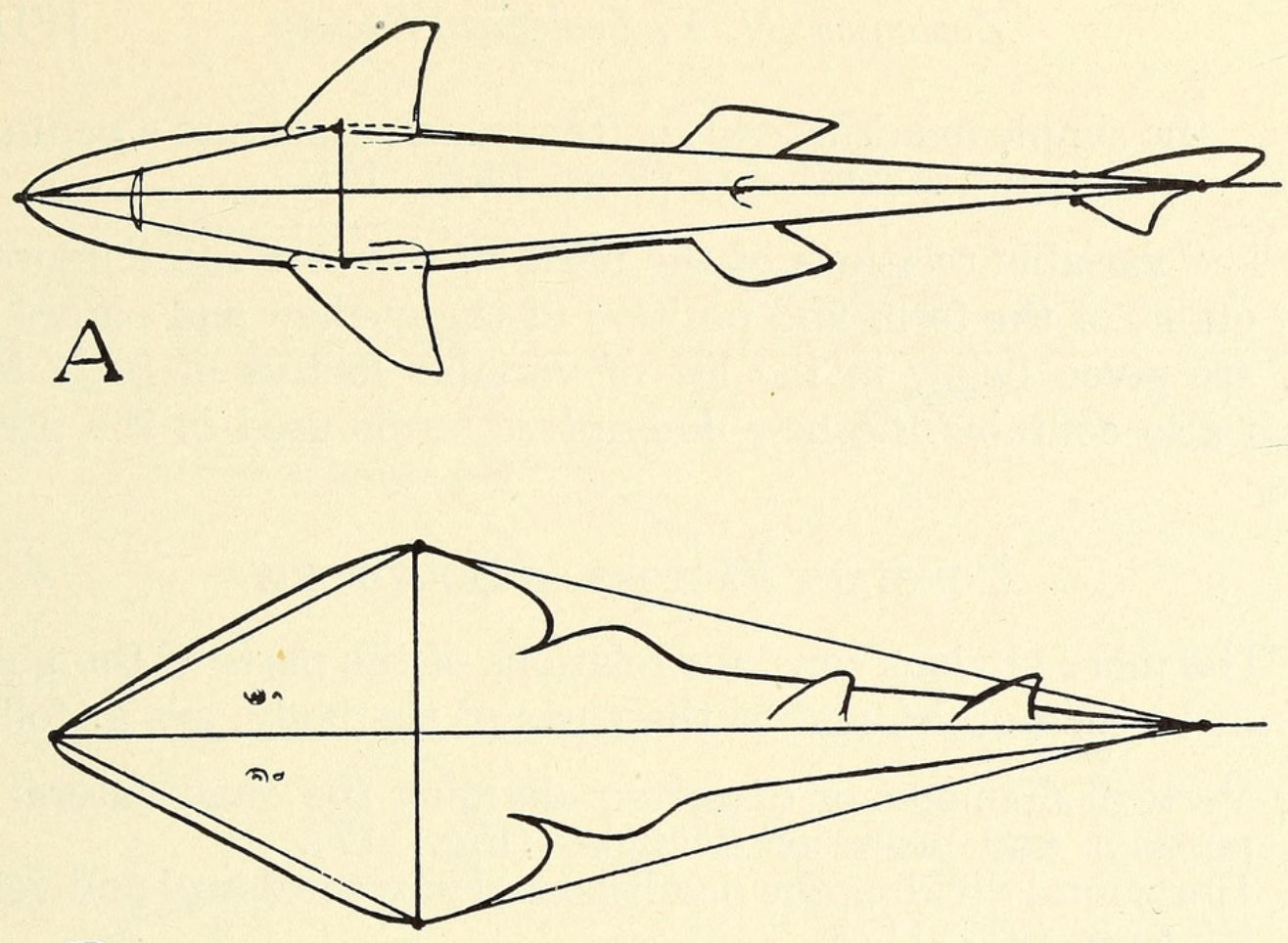

B
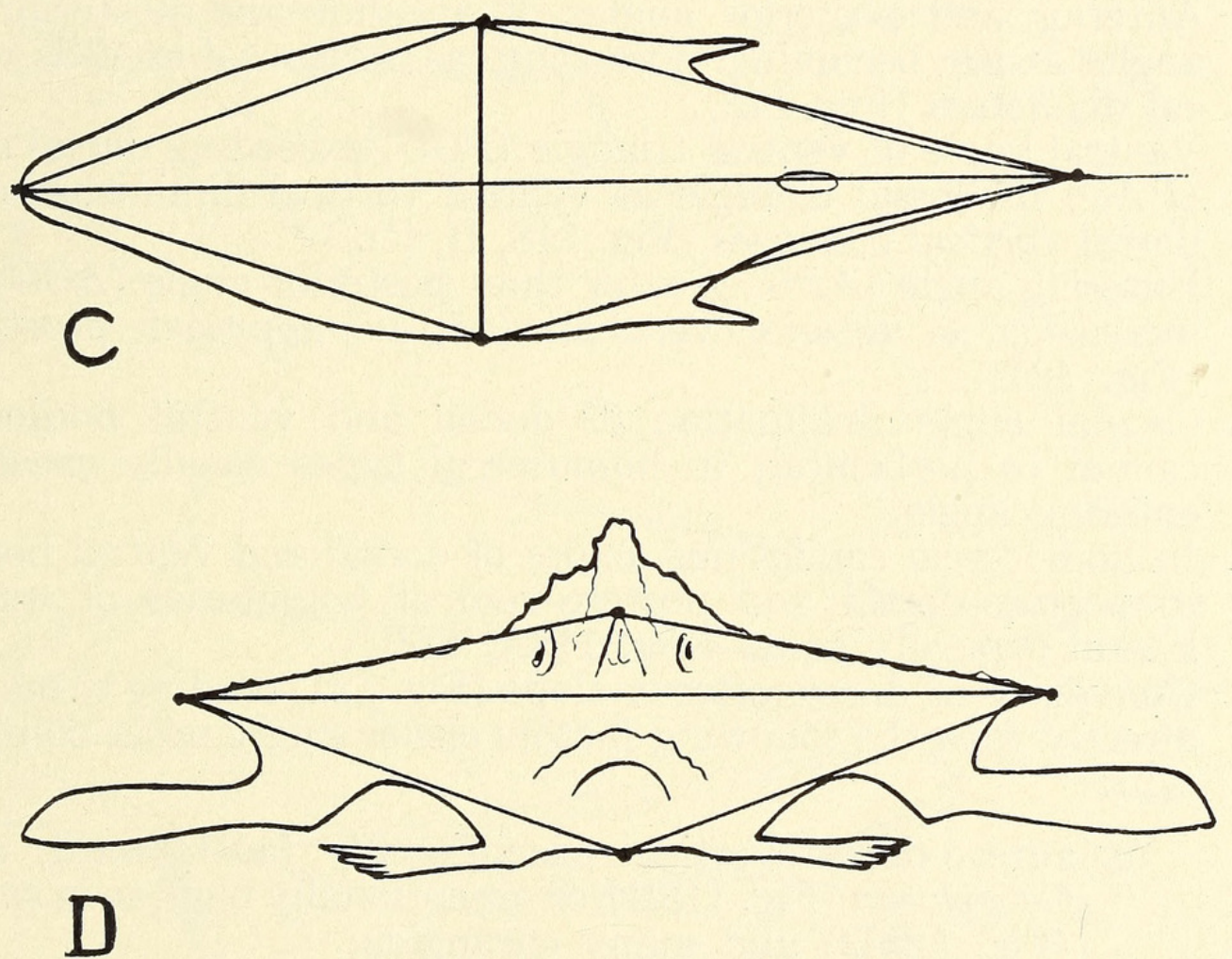

Fig. 120. The bounding quadrilateral figures in the ventral, dorsal and front views. A, Shark (Squalus acanthias), ventral view; B, Rhinobatus (Rhinobatus lentiginosus). dorsal view; C, Trunk-fish (Lactophrys bicaudalis), ventral view; D, Bat-fish (Ogcocephalus vespertilio), front view. Outlines after Jordan and Evermann. 
the simple quadrilateral is often transformed into a pentagon, as in many Acanthopts (Figs. 140B, 151C).

The variable relations of the parts of the rectilinear figures to each other, of the form and position of the median and paired fins, etc., are given below in the list of variable factors of body form, which also contains the new descriptive terms used in the present paper.

\section{CONSTANT FACTORS OF BODY-FORM}

The more obvious constant relations of the parts of the quadrilaterals to each other, and to the parts of the body, are as follows:

1. Vertical diameter or diameters dividing the quadrilateral into anterior and posterior triangles (Fig. 117).

2. Horizontal dividing the quadrilateral into the dorsal and ventral triangles (Fig. 117).

3. Dorsal and ventral angles of dorsal and ventral triangles obtuse and becoming more obtuse as horizontal exceeds vertical (Fig. 118).

4. Anterior and posterior angles of anterior and posterior triangles acute; becoming more acute as horizontal exceeds vertical diameters (Fig. 118).

5. Ventral angle of ventral triangle $(P G O)$ exceeding dorsal angle $(P A O)$ of dorsal triangle as ventral vertical diminishes or as dorsal vertical increases (Fig. 118, B, C).

6. Entering angle $(A P G)$ greater than posterior angle $(A O G)$ and increasing as anterior verticals ( $a d$, $a v)$ approach prosthion. (Fig. 121.)

7. Caudal angle (inclination of dorsal and ventral borders of caudal to horizontal) in homocercal types usually exceeding entering angle.

8. In homocercal caudal fins angles of dorsal and ventral borders to postero-dorsal and postero-ventral boundaries of quadrilateral typically equal (Fig. 119A, 124C).

9. Convexity of dorso-anterior slope (Fig. 121) tending to increase directly with the following factors either singly or in combination:

(a) antero-dorsal vertical exceptionally far forward, as in Coryphæna (Fig. 118B), or exceptionally high, as in sparids (Fig. 126D) and many carangids;

(b) eye very large and at the same time far forward and high, as in Alticus atlanticus, Upeneus maculatus, Mycotphum opalinum (Fig. 121);

(c) mouth small and not directed upward, as in many 

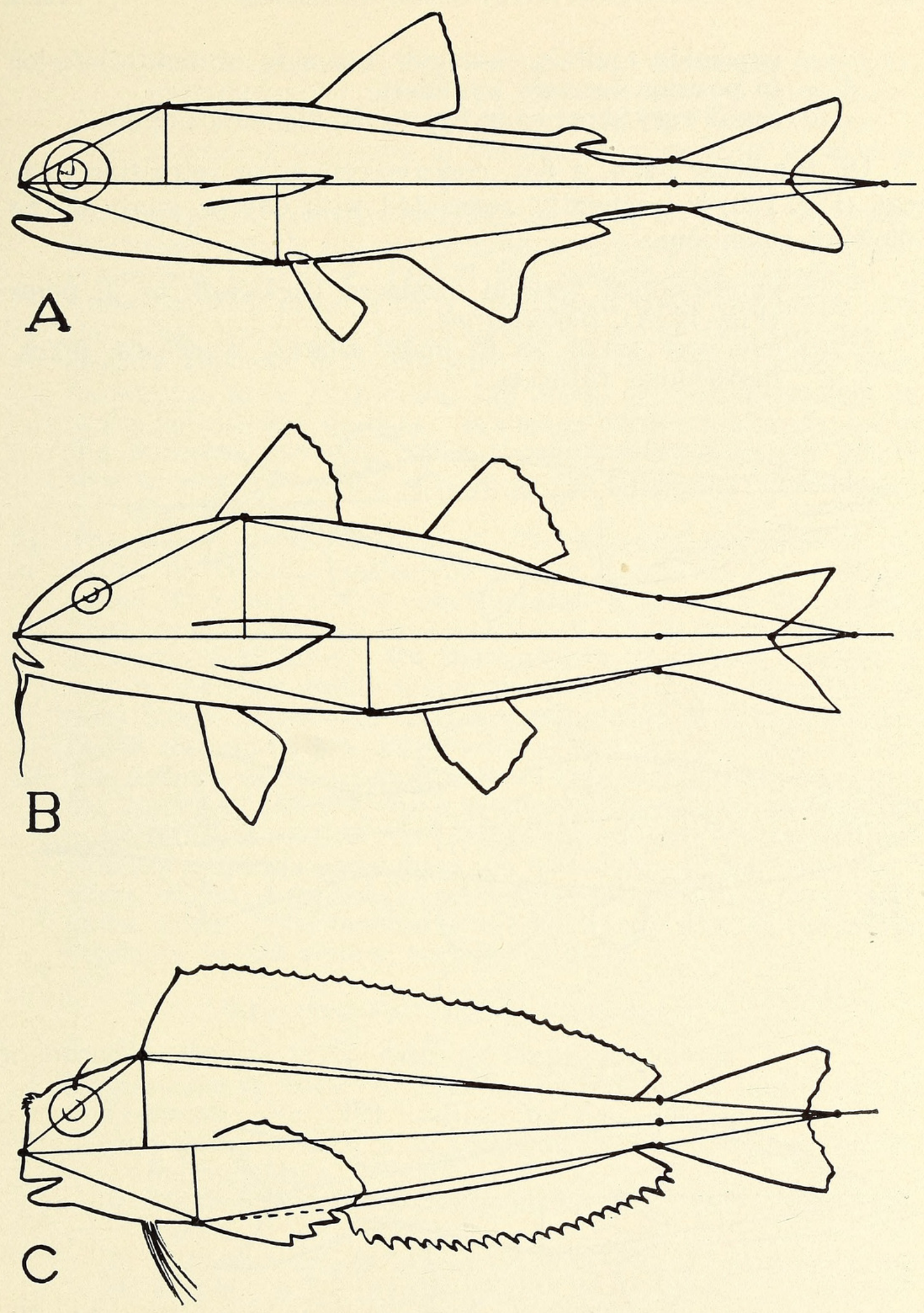

Fig. 121. Fishes with convex dorso-anterior slope and high entering angles, A, Myctoph!d (Myctophum opalinum); B, Mullet (Upeneus maculatus); C, Blenny (Alticus atlanticus). Outlines after Jordan and Evermann. 
cyprinids, mullids, carangids, sciænids, or mouth inferior in position (certain mullids);

(d) snout very short as in cyprinids, blennies, mullids.

On the other hand, a flat, concavo-convex or retreating forehead (Fig. 122) is frequently associated with one or more of the following conditions:

(a) antero-dorsal vertical displaced backward, as in pikes (Fig. 122A), Bathypterois;

(b) eye very small, as in many sharks, sturgeons, pikes, barracudas, catfishes;
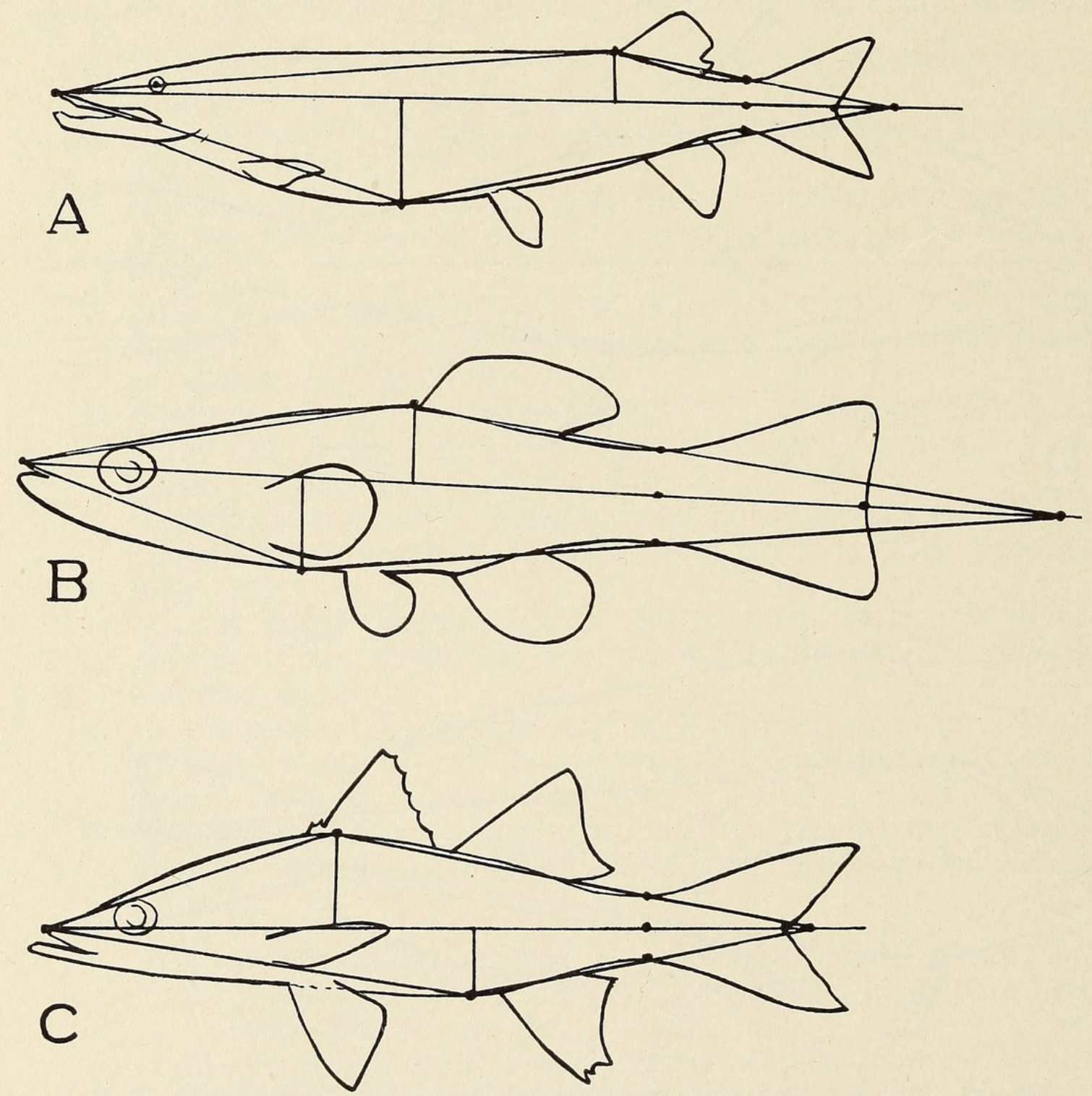

Fig. 122. Fishes with flat dorso-anterior slope and low entering angles. A, Pike (Lucius masquinongy); B, Killifish (Fundulus diaphanus) $\sigma^{7}$ : C, Snook(Oxylabrax undecimalis). Outlines after Jordan and Evermann. 
(c) mouth large and directed upward, many percomorphs, barracudas; or small and directed upward (pœciliids);

(d) snout long, as in sturgeons, gar-pikes, Trichiurus etc;

(e) ascending processes of premaxillæ very long, as in $H æ$ mulon, Gerres.

10. Antero-ventral contour, forming the lower border of the entering wedge, nearly always protruding convexly below the corresponding boundary $(P G)$ of the quadrilateral, especially in free-swimming fishes with a compressed body and head. On the other hand, the antero-ventral contour is often flat or slightly concave in forms with depressed head, either freeswimming, as in Pristis and the pikes, or bottom-feeding, as in the batoids and mullids. A convex border doubtless pushes the water to one side, while a concave lower border would tend to produce a slight suction on the under side of the head, and thus to lower it.

11. The postero-dorsal contour of the back and the base of the dorsal fin usually correspond rather closely to the posterodorsal boundary of the quadrilateral, which is a line drawn from the apex through the epipygidion. This is especially true in long-bodied fishes. On the contrary, the dorsal contour is apt to protrude widely above the postero-dorsal boundary in deep bodied fishes that have a combination of a high anterodorsal $(a d)$ and a low postero-dorsal vertical ( $p d$ ) (Fig. 124D).

12. The postero-ventral contour seldom approaches the corresponding boundary $(G O)$ of the quadrilateral as closely as does the postero-dorsal contour; frequently the postero-ventral contour retreats proximad away from the boundary. This "cutaway" effect, which is especially marked in fishes with a deep belly (Figs. 123B, 127), facilitates the backward flow of the water displaced by the ventral part of the body.

\section{VARIABLE FACTORS OF BODY-FORM}

I. Variable relations of the parts of the quadrilaterals

1. Proportions of total anterior vertical diameter $(a d+a v)$ to body length ${ }^{1}(P p)$ (Fig. 124).

(a) Vertical $=$ or $<1 / 10$ body length (Fig. 124A) (hyperdolichosomatic)

(b) Vertical $>1 / 10$ to $1 / 5$ inclusive (Fig. 124B) (dolichosomatic)

(c) Vertical $>1 / 5$ to $1 / 3$ inclusive (Fig. 124C) (mesosomatic)

(d) Vertical $>1 / 3$ (hypsisomatic) (Fig. 124D).

2. Antero-posterior relations of apex to gasterion.

(a) Gasterion behind apex, $i$. e., ventral vertical behind

1 Prosthion to pygidion. 
dorsal vertical; e. g., Neomænus apodus, (Fig. 125A) Calamus proridens (Fig. 126D). (gasterion postapical).

(b) Gasterion immediately below apex, ventral vertical im-
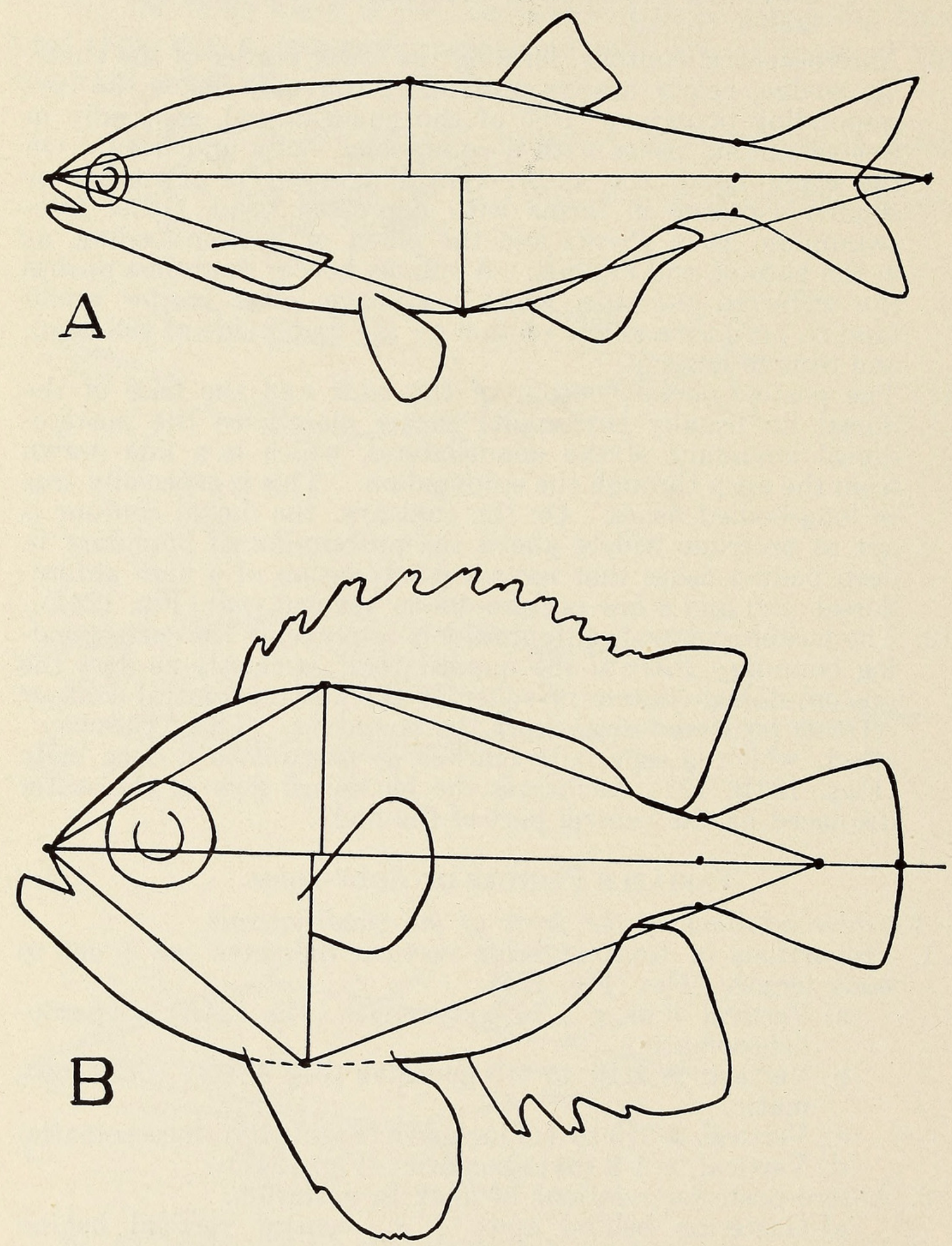

Fig. 123. Cutaway condition of postero-ventral contour. A, Hiodon tergisus; B, Pseudopriacanthus altus. Outlines after Jordan and Evermanr. 

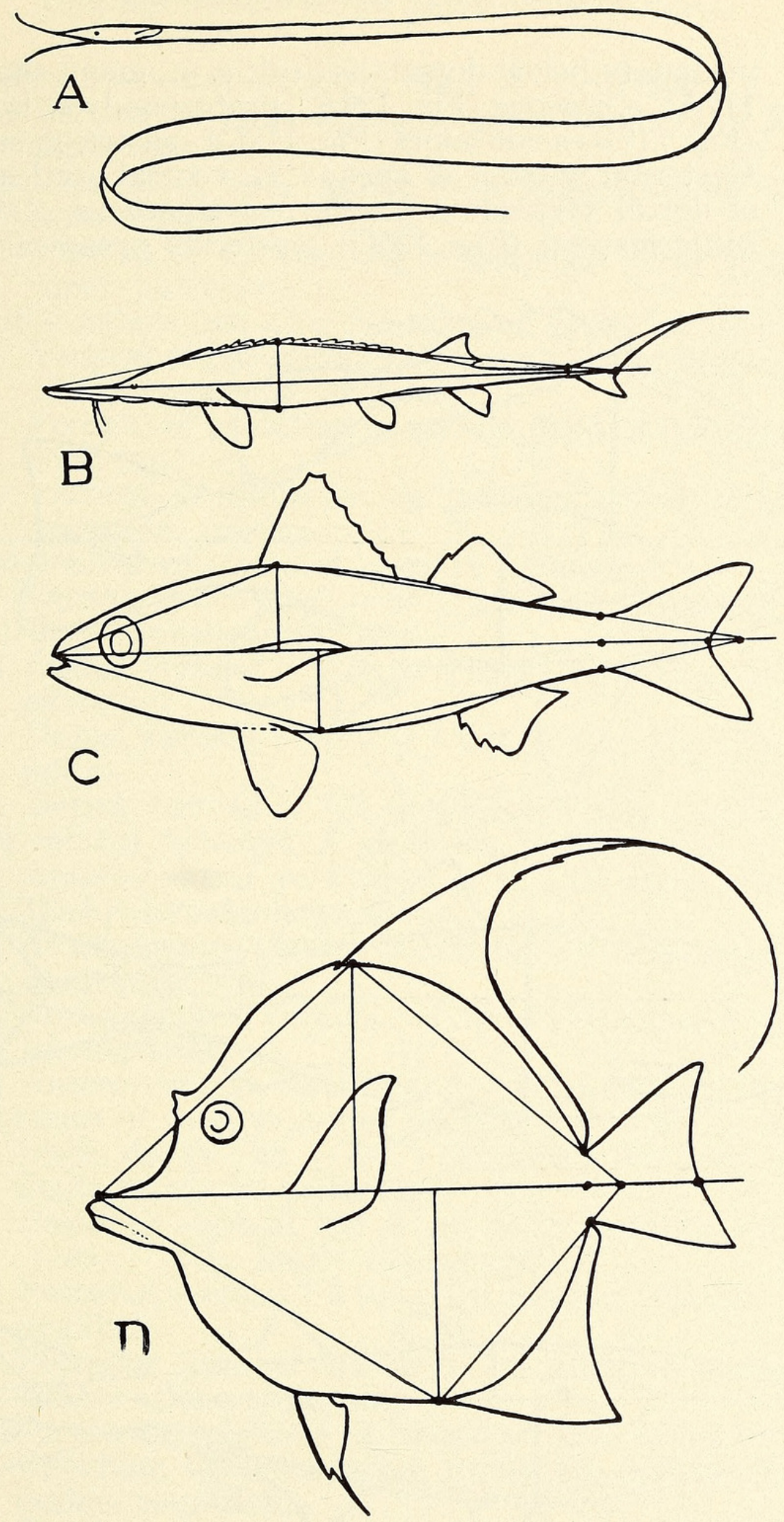

Fig. 124. The four types of body-form based on the ratio of depth to body length (prosthion to pygidion). A, Hyperdolichosomatic (Labichthys elongatus); B, Dolichosomatic (Scaphirhynchus platorhynchus); C, Mesosomatic (X€nocys jessiæ); D, Hypsisomatic (Zanclus cornutus). Outlines after Jordan and Evermann. 
mediately below dorsal vertical; e. g., many sharks (Fig. 117A), sturgeons (Fig. 124B), protospondyls, isospondyls (Fig. 117B) acanthopts (Fig. 117C) (gasterion subapical).

(c) Gasterion in front of apex; $i$. e., ventral vertical in front of dorsal vertical; e. g., Tarpon atlanticus, Atherinopsis californiensis) (Fig. 125C) (gasterion preapical).
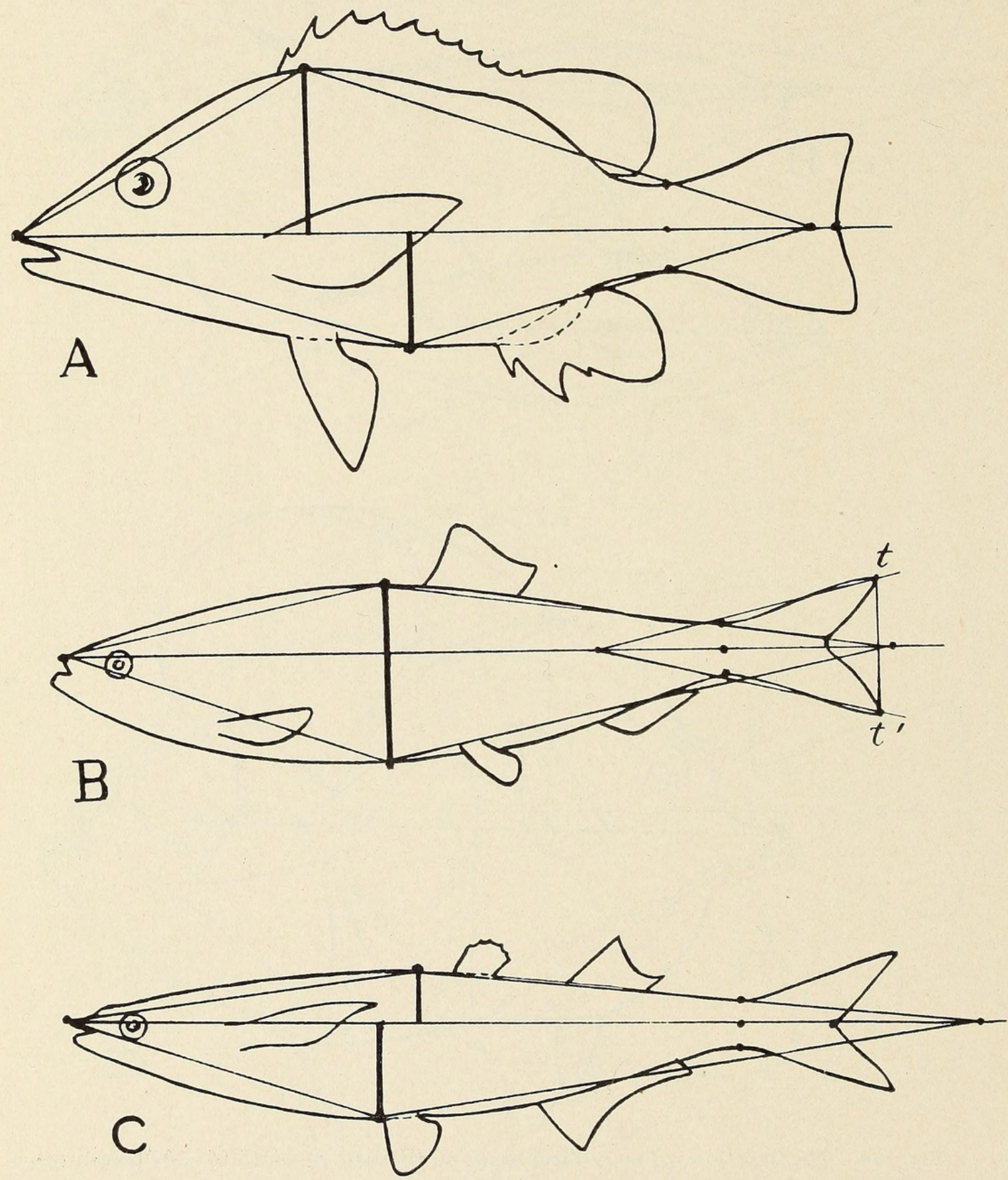

Fig. 125. Varying antero-posterior relations of apex to gasterion. A, Gasterion postapical (Neomænis apodus); B, Gasterion subapical (Clupea harengus); C. Gasterion preapical (Atherinopsis californiensis). Outlines after Jordan and Evermann. 
3. Antero-posterior relations of apex to horizontal.

(a) Vertical of apex falling in anterior third of horizontal (apex anterior).

(b) Vertical of apex falling in middle third of horizontal (apex median).

(c) Vertical of apex falling in posterior third of horizontal (apex posterior)

4. Variable antero-posterior relations of gasterion to horizontal.

(a). Vertical of gasterion in anterior third of horizontal (Fig. 121C) (gasterion anterior).

(b) Vertical of gasterion in middle third of horizontal (gasterion median).

(c) Vertical of gasterion in posterior third of horizontal (gasterion posterior).

5. Dorso-ventral relations of apex to horizontal.

(a) Dorsal vertical $(a d)=$ or $<1 / 20$ body length (Fig. 126A) (hyperdolichonotic).

(b) Dorsal vertical $>1 / 20$ to $1 / 10$ inclusive (Fig. 126B) (dolichonotic)

(c) Dorsal vertical $>1 / 10$ to $1 / 6$ inclusive (Fig. 126C) (mesonotic).

(d) Dorsal vertical $>1 / 6$ (hypsinotic) (Fig. 126D).

6. Dorso-ventral relations of gasterion to horizontal.

(a) Antero-ventral vertical $=$ or $<1 / 20$ body length (Fig. 126A) (hyperdolichogastric).

(b) Antero-ventro vertical $>1 / 20$ to $1 / 10$ inclusive (Fig. 126B) (dolichogastric).

(c) Antero-ventral vertical $>1 / 10$ to $1 / 6$ inclusive (Fig. 126C) (mesogastric).

(d) Antero-ventral vertical >1/6 (Fig. 127) (bathygastric).

7. Proportions of total posterior vertical $(p d+p v)$ to maximum body depth $(a d+a v)$. (Posterior vertical minimum depth of caudal peduncle)

(a) Posterior vertical $(p d+p v)<1 / 4$ anterior vertical ( $a d$ $+a v$ ). (Fig. 128B) (leptopygidial).

(b) Posterior vertical $1 / 4$ to $<1 / 2$ anterior vertical. (nomopygidial).

(c) Posterior vertical $1 / 2$ or $>1 / 2$ anterior vertical (Fig. 128A). (macropygidial).

8. Antero-posterior relations of opisthion and uranion.

(a) Opisthion behind uranion (opisthion posturanic). The normal condition.

(b) Opisthion coincides with uranion (opisthion uranic) (Fig. 117C).

(c) Opisthion in front of uranion (opisthion preuranic) (Fig. $128 \mathrm{~B}, 127 \mathrm{C}, 126 \mathrm{D}, 124 \mathrm{D}, 123 \mathrm{~B})$. 
A
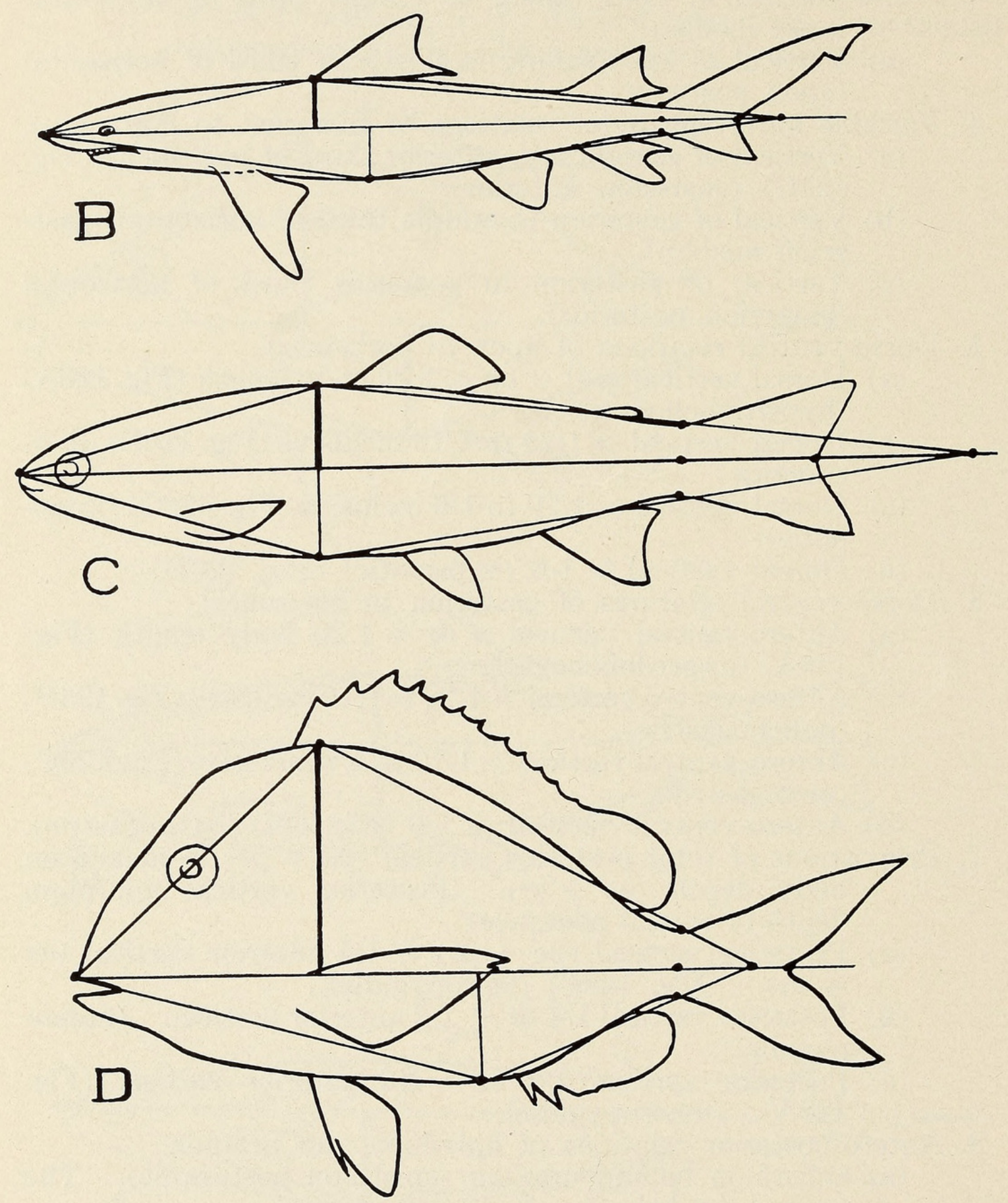

Fig. 126. Varying depth of back. A, Hyperdolichonotic (Nemichthys avocetta); B, Dolichonotic (Hypoprion brevirostris); C, Mesonotic (Salmo clarkii stomias); D, Hypsinotic (Calamus proridens). Outlines after Jordan and Evermann. 

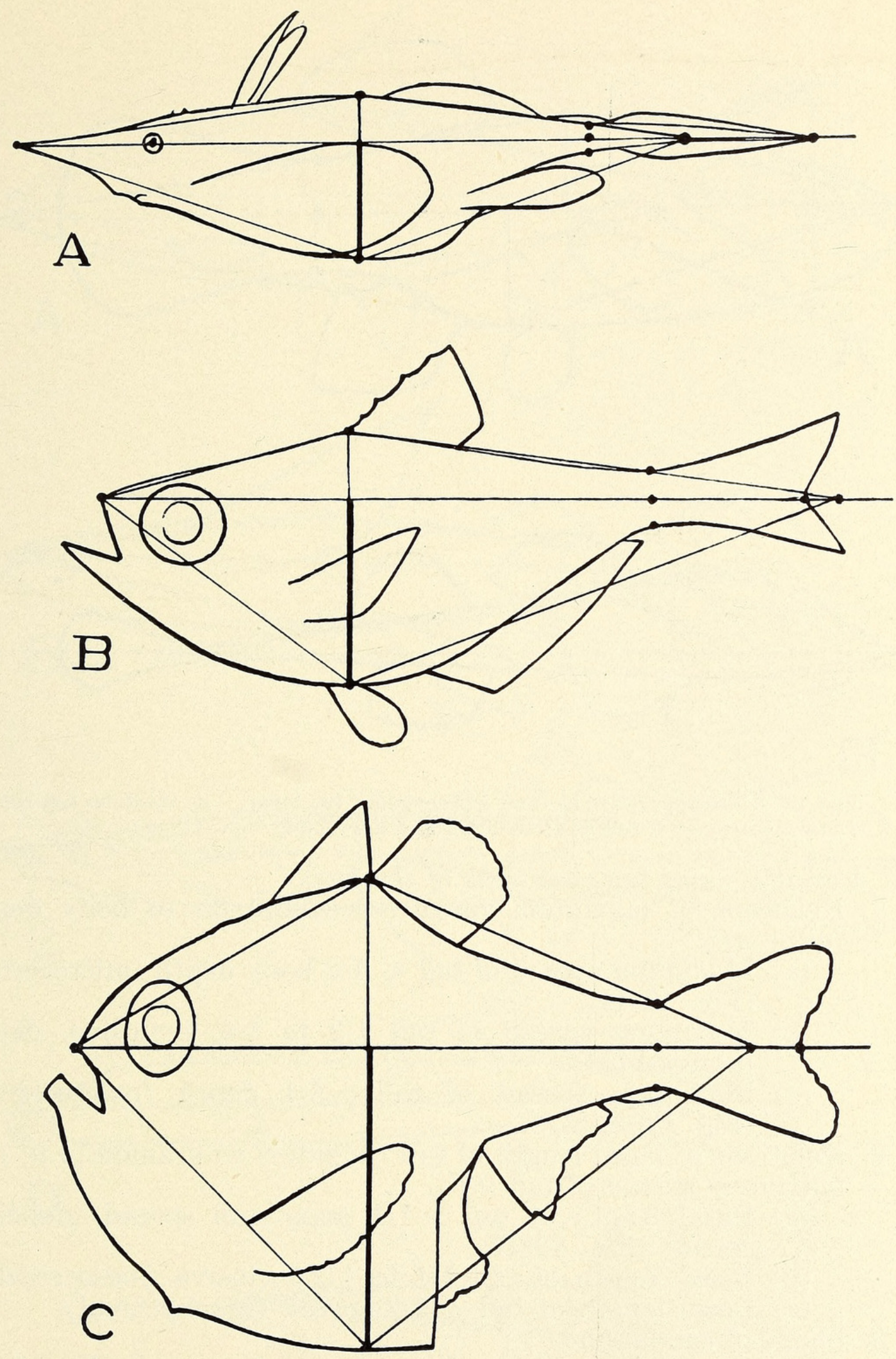

Fig. 127 Bathygastric forms. A, Harriotta raleighana; B, Pempheris poeyi; C, Argyropelecus olfersi. Outlines after Jordan and Evermann. 

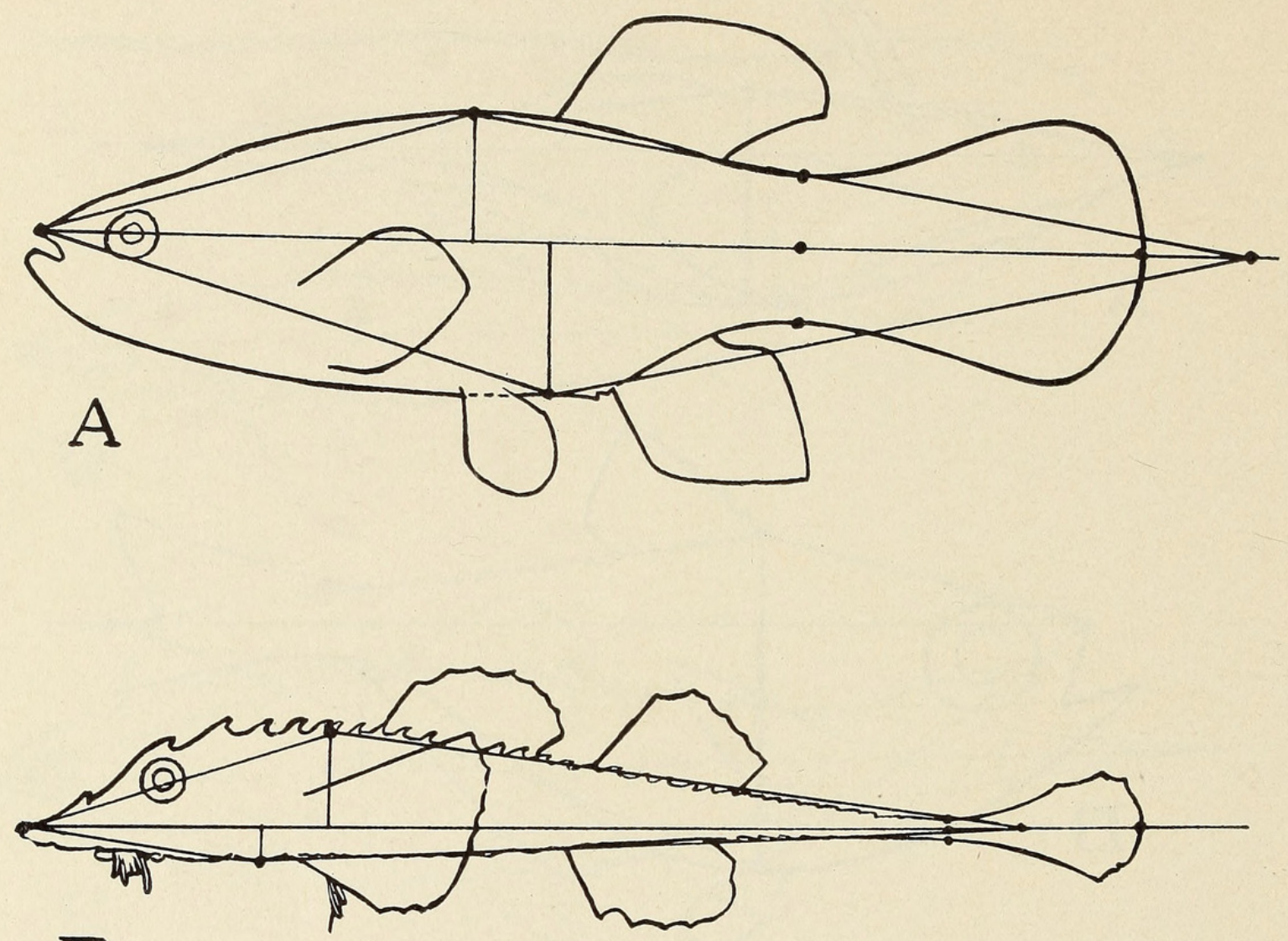

$\mathrm{B}$

Fig. 128. Macropygidial (A) and leptopygidial (B) forms. A, Fundulus heteroclitus; B, Podothecus veterinus. Outlines after Jordan and Evermann.

II. Variable forms and positions of the fins.

1. Relations of maximum spread of caudal fin to body depth $(a d+a v)$.

(a) Maximum spread of tail $<1 / 3$ body depth (microcercal) (Fig. 129D).

(b) Maximum spread of tail $1 / 3$ to $3 / 4$, inclusive, depth (nomocercal).

(c) Maximum spread of tail $<3 / 4$ depth (macrocercal) (Fig. 129A, B, C).

2. Relations of basal length of tail (pygidion to uranion $[p u]$ ) to maximum spread of tail $\left(t t^{\prime}\right)$.

(a) Basal length of tail $>1 / 1$ maximum spread (dolichocercal) (Fig. 128B).

(b) Basal length of tail $1 / 1$ to $1 / 2$ inclusive (mesocercal).

(c) Basal length of tail $<1 / 2$ spread (brachycercal).

3. Shape of caudal fin.

(a) Caudal fin hypocercal (reversed heterocercal) (Fig. 130A)

(b) Caudal fin heterocercal (epicercal). Varieties of the heterocercal type are illustrated and named in Figs. 130, 131, 132, and 133. 

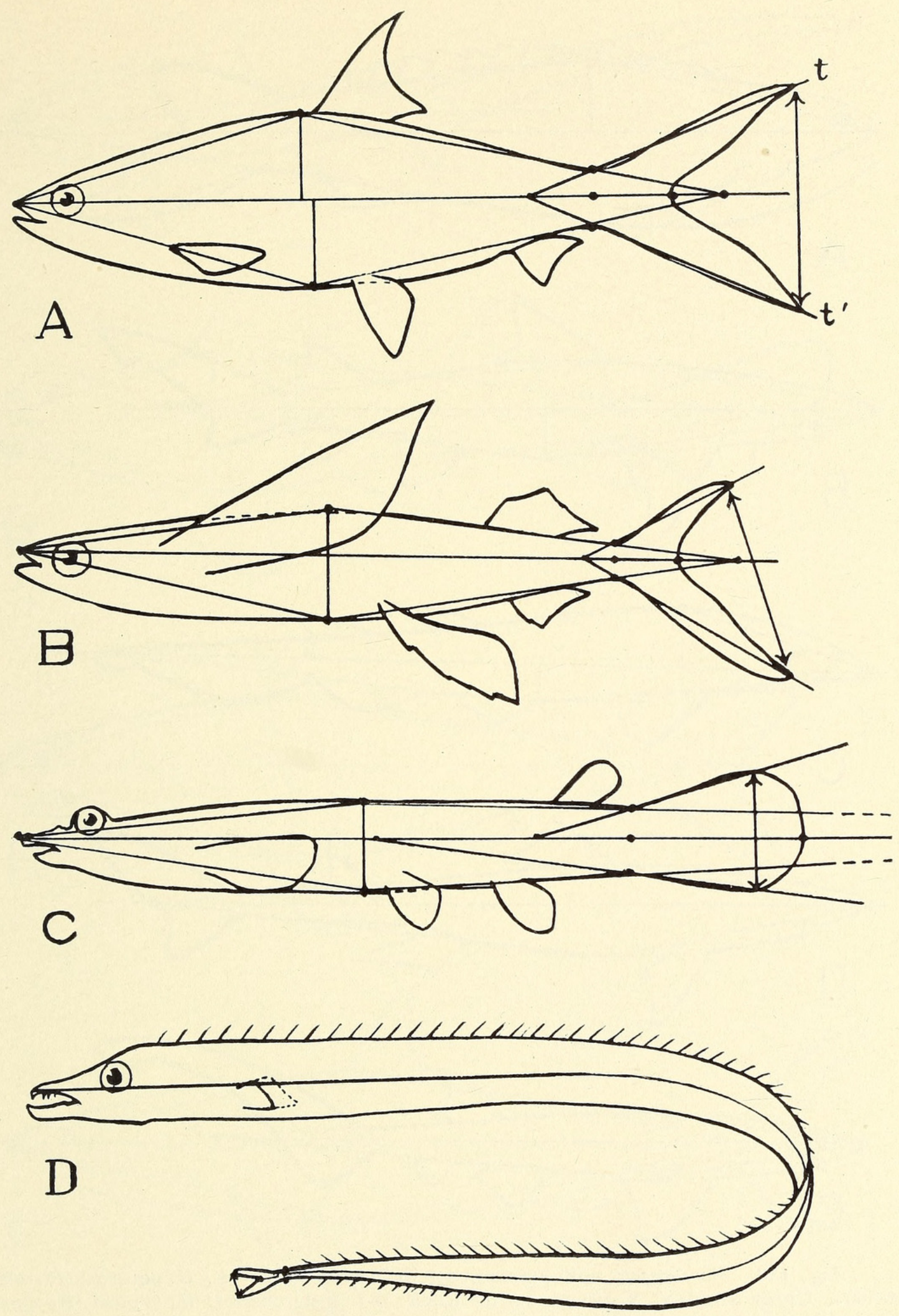

Fig. 129. Macrocercal (A, B, C) and microcercal (D) forms. A, Chanos chanos; B, Cypselusus californicus; C, Anableps dovii; D, Lepidopus caudatus. Outlines after Jordan and Evermann. 

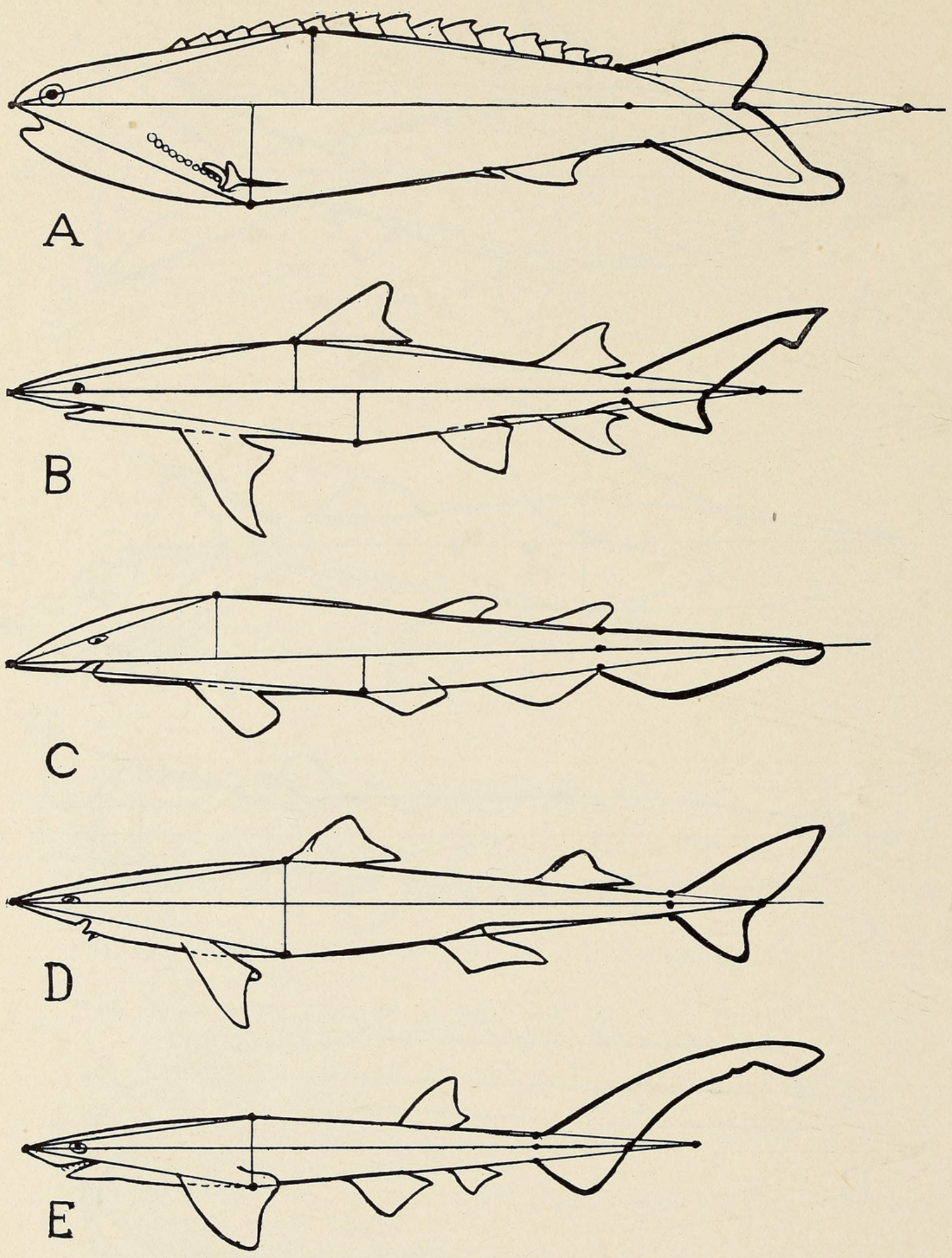

Fig. 130. Hypocercal and heterocercal (epicercal) tails. A, Hypocercal (Pterolepis nitidus, Upper Silurian, Norway). After Kiaer; B-I, Heterocercal: B, typical (Hypoprion brevirostris); C, horizontal (Scylliorhinus profundorum); D, asymmetrical (Squalus acanthias); E, elongate (Notorhynchus maculatus). Outlines after Jordan and Evermann. 

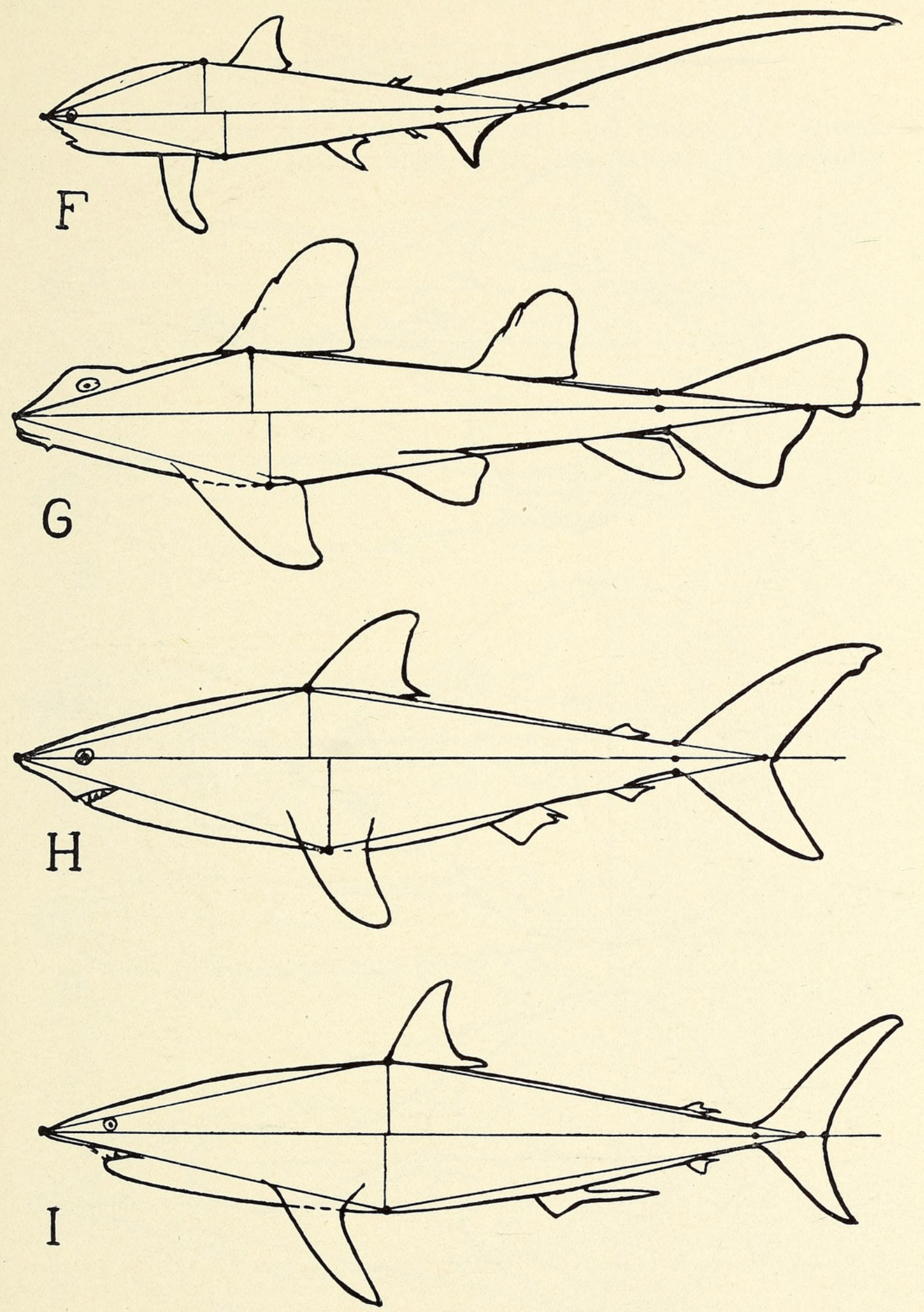

Fig. 131. Heterocercal types continued. F, Perelongate (Alopias vulpes); G, robust (Gyropleurodus francisci); H, bifurcate (Lamna cornubica); I, subcrescentic (Isurus dekayi). Outlines after Jordan and Evermann. 

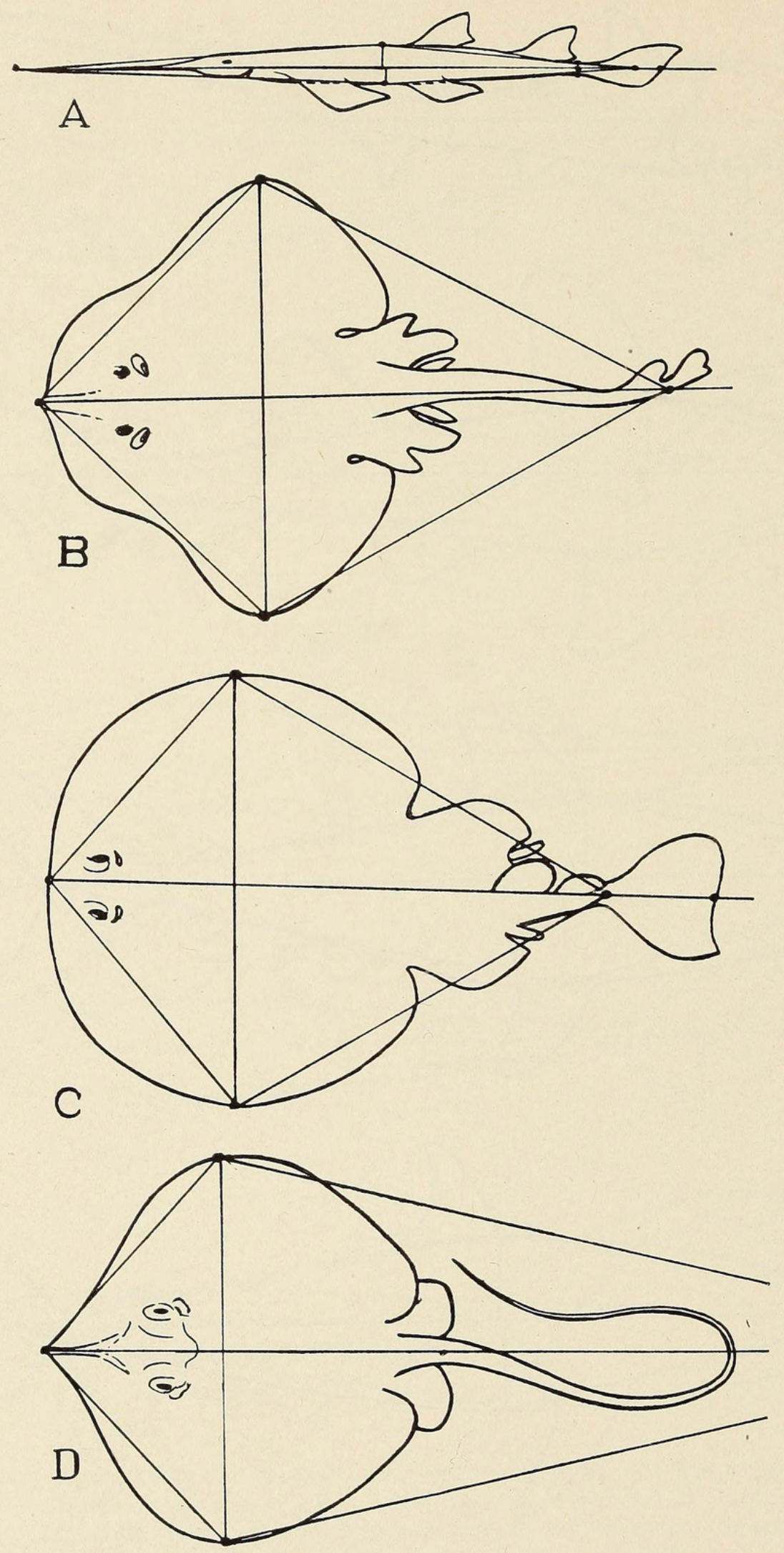

Fig. 132. Modified heterocercal types. A, Scalene (Pristis pectinatus); B, bipinnate (Raja occellata); C, truncate (Tetranarce occidentalis); D, filiform (Dasyatis sabina). Outlines after Jordan and Evermann. 
(c) Caudal fin tristichopterous (Fig. 133D).

(d) Caudal fin diphycercal (Fig. 133C).

(e) Caudal fin hemiheterocercal: $(\alpha)$ lunate, $(\beta)$ bifurcate, $(\gamma)$ crescentic, $(\delta)$ truncate, $(\varepsilon)$ convex, $(\zeta)$ spatulate.
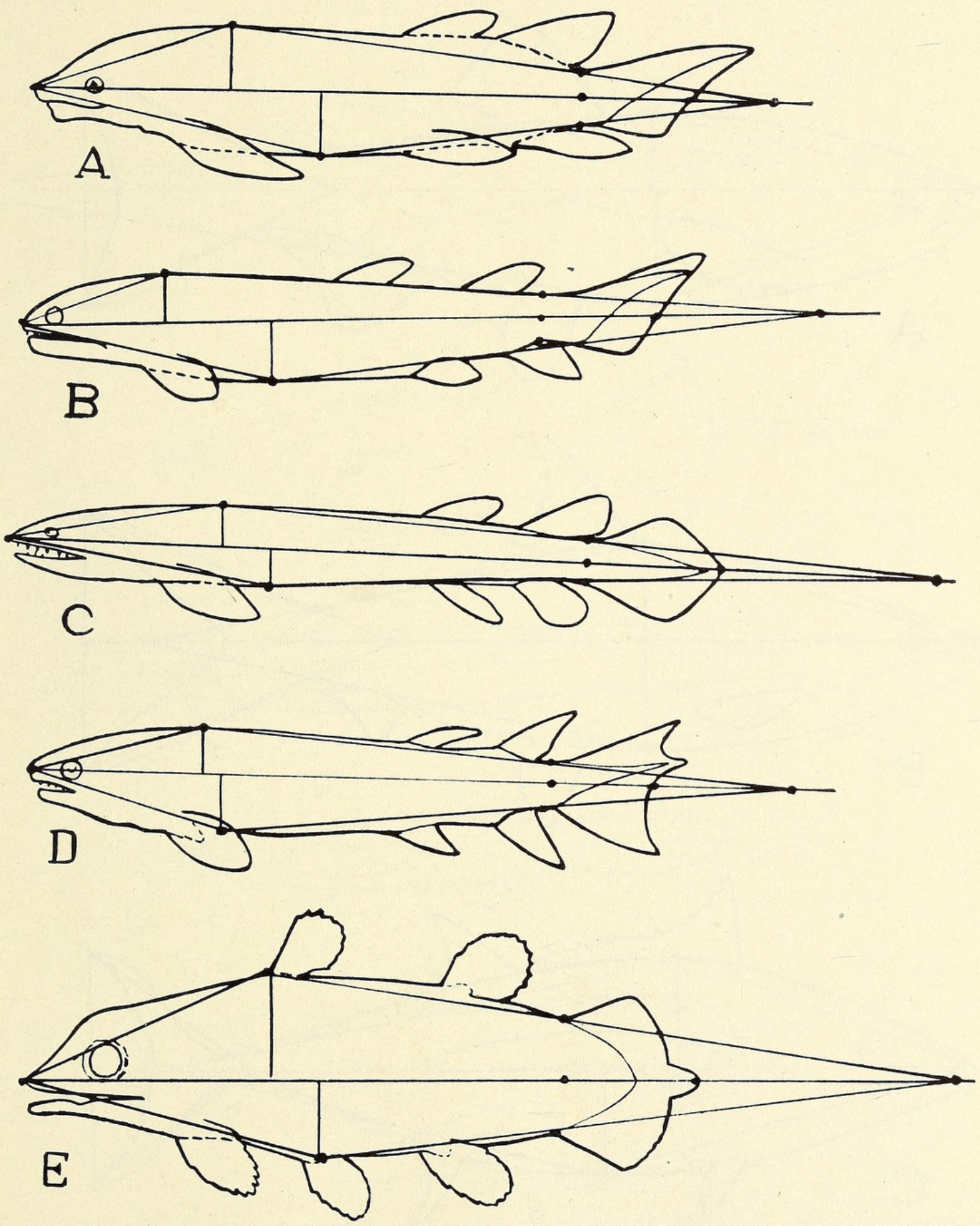

Fig. 133. Modified heterocercal types (continued). A, Acute (Dipterus valenciennesii); B, acute (Osteolepis macrolepidotus); C, diphycercal (Glyptopomus kinnairdii); D, tristichopterous concave (Tristichopterus alatus); E, tristichopterous convex (Undina gulo). All from Goodrich after Traquair. 
(f) Caudal fin homocercal. The varieties of the homocercal type are shown in Figs. 134, 135.

(g) Caudal fin gephyrocercal. The varieties of the gephyrocercal type are shown in Fig. 136.
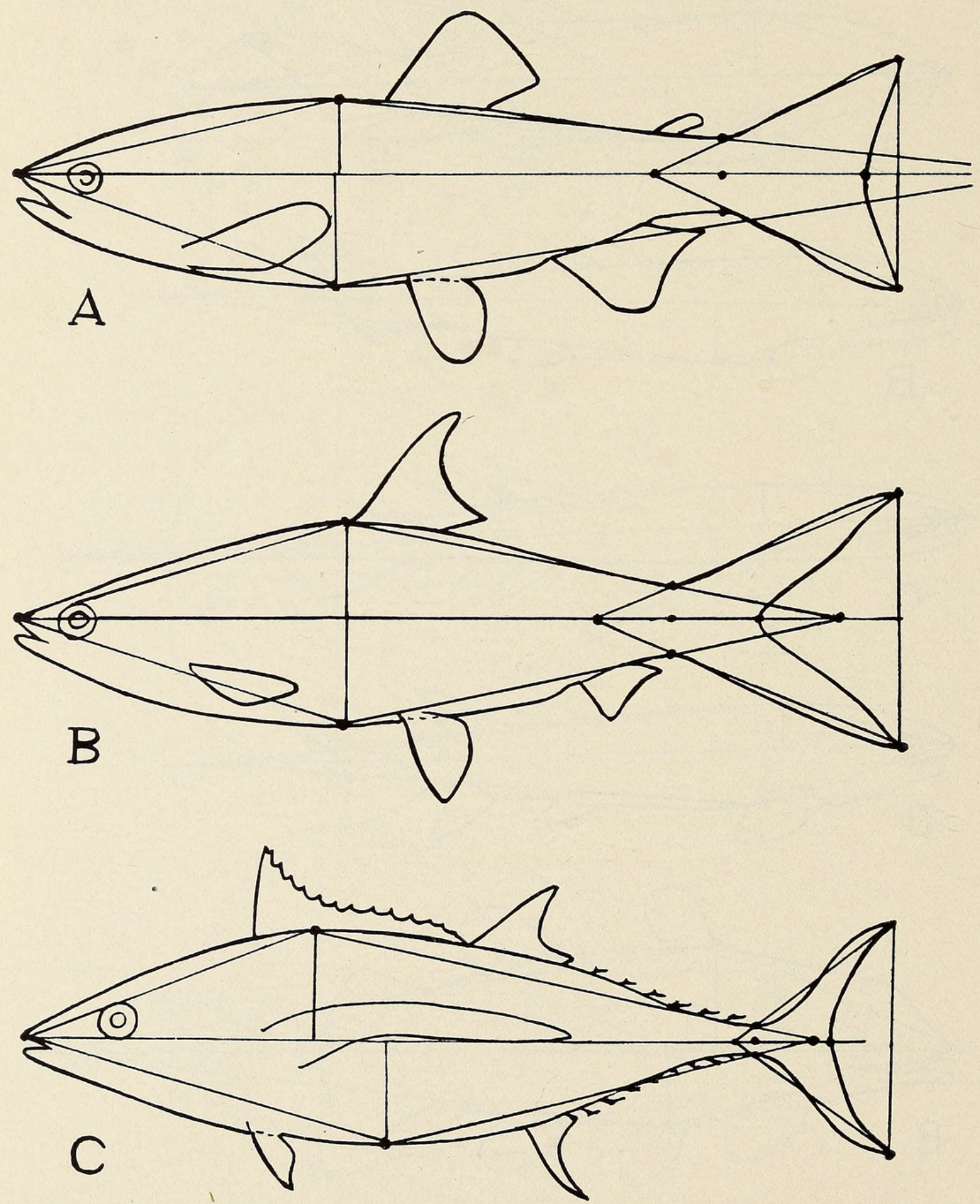

Fig. 134. Homocercal types. A, Lunate (Oncorhynchus nerka); B, bifurcate (Chanos chanos): C, crescentic (Germo alalunga). Outlines after Jordan and Evermann. 

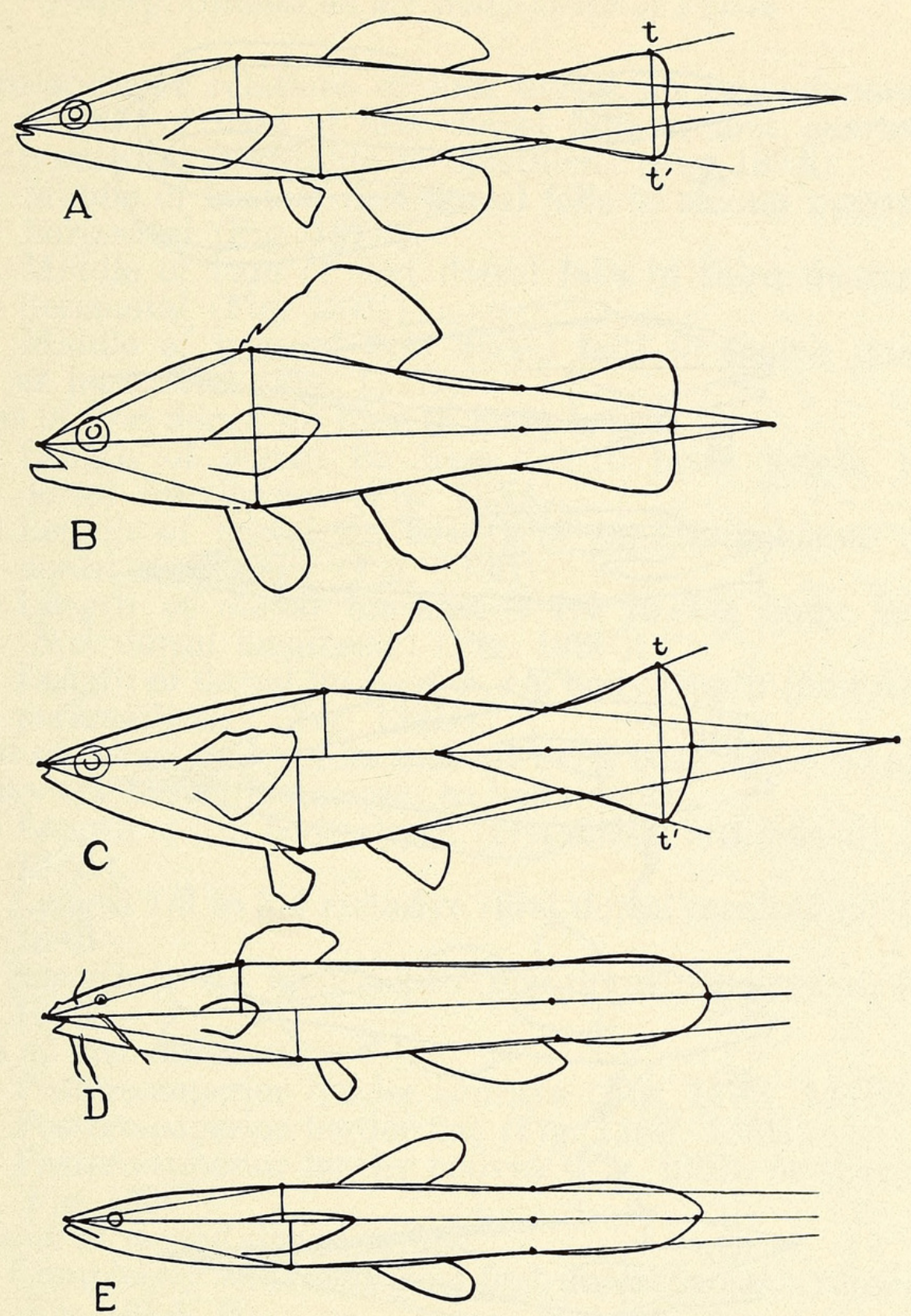

E

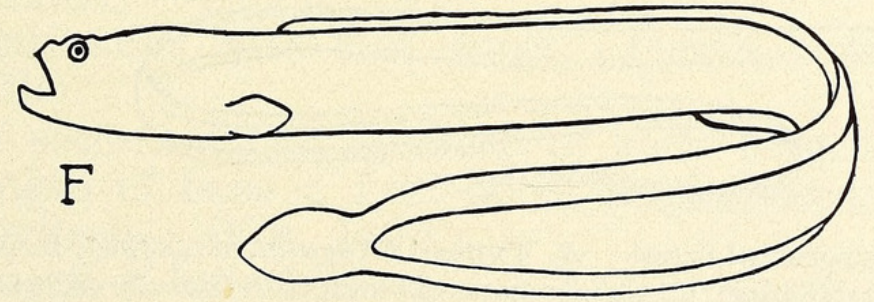

Fig. 135. Homocercal types (continued). A, Truncate (Fundulus zebrinus); B, truncate emarginate (Aphredoderus sayanus); C, convex (Pæcilia presidionis); D, spatulate convex (Schilbeodes exilis); E, spatulate pointed (Chologaster cornutus); F, gephyrocercal incipient (Cryptacanthodes maculatus). Outlines after Jordan and Evermann. 

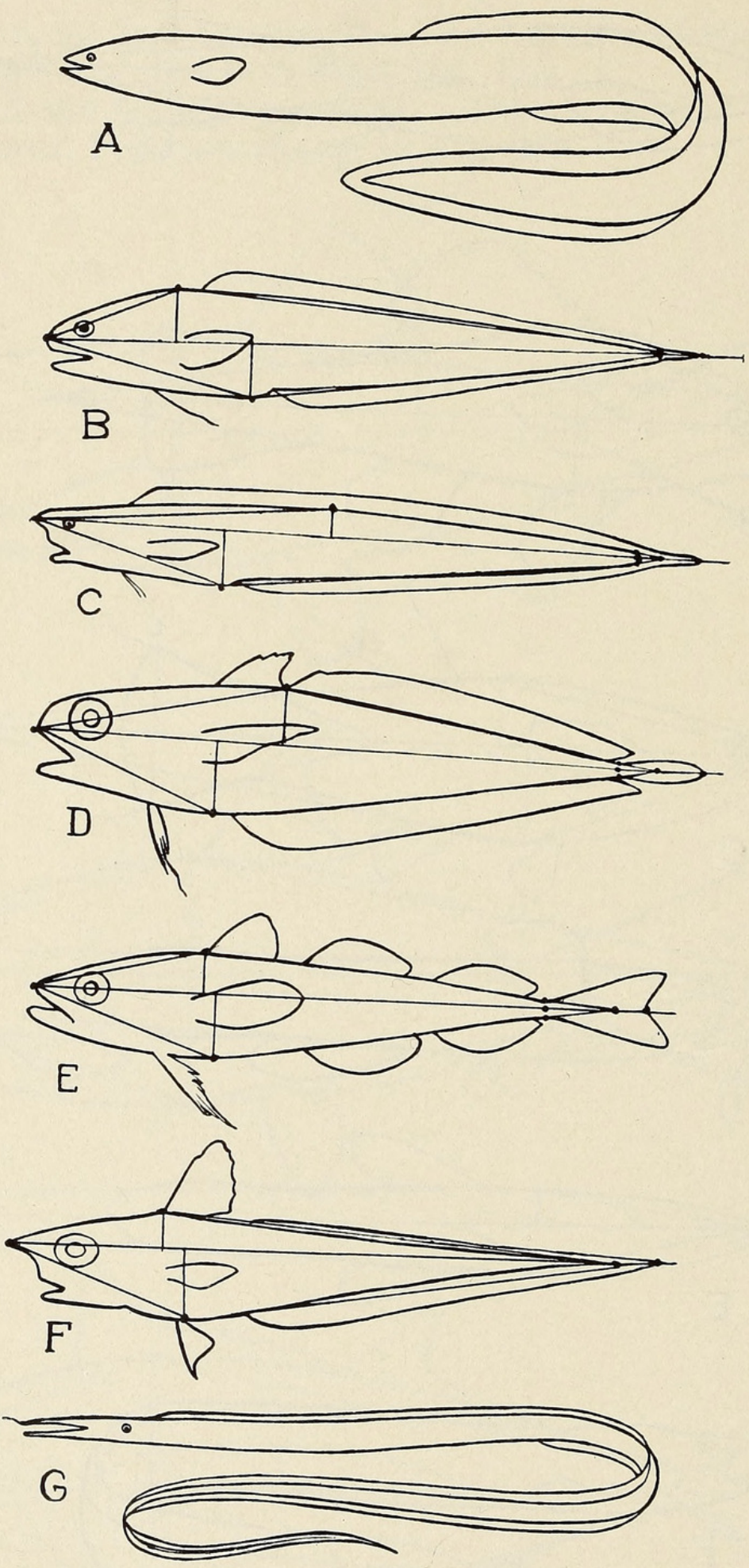

Fig. 136. Gephyrocercal types. A, Typical (Anguilla chrysypa); B, pointed or diphycercoid (Neobythites marginatus); C, pseudomocercal incipient (Barathrodemus manatinus); D, pseudomocercal spatulate (Physiculus fulvus); E, pseudomocercal lunate (Porogadus saida); F, gephyrocercal hypural (Cœlorhynchus carminatus); G, gephyrocercal filiform (Veneficia procera). Outlines after Jordan and Evermann. 
4. Antero-posterior relations of first dorsal fin to horizontal.

(a) Middle of base of first dorsal falls in first quarter of horizontal (prosthion to opisthion) (Fig. 137A).

(b) Middle of base of first dorsal falls in second quarter of horizontal (Fig. 137B).

(c) Middle of base of first dorsal falls in third quarter of horizontal (Fig. 137C).

(d) Middle of base of first dorsal falls in fourth quarter of horizontal (Fig. 137D).

5. Extent of first dorsal fin base to body length.

(a) Length of dorsal fin base $<1 / 10$ body length (first dorsal brevibasic) (Fig. 138A).

(b) Length of dorsal fin base $1 / 10$ to $1 / 4$ inclusive (first dorsal medibasic) (Fig. 138B).

(c) Length of dorsal fin base $>1 / 4$ to $1 / 2$ body length (first dorsal longibasic) (Fig. 138C).

(d) Length of dorsal fin base $>1 / 2$ body length (first dorsal perlongibasic) (Fig. 138D).

6. Height of dorsal fin from its summit to its base measured along the rays (excluding filaments), to body depth.

(a) Length $<1 / 3$ body depth (first dorsal breviradial) (Fig. $139 \mathrm{~A})$.

(b) Length $1 / 3$ to $3 / 4$ inclusive (first dorsal mediradial) (Fig. 139B).

(c) Length $>3 / 4$ body depth (first dorsal longiradial) (Fig. 139C).

7. Shape of first dorsal fin.

(a) Postero-superior border concave (Fig. 137B, 134B).

(b) Postero-superior border flat (Fig. 135F, 136B).

(c) Postero-superior border convex (Fig. 135B) or spatulate (Fig. 135C).

8. Relations of second dorsal to first.

(a) Completely separated from first dorsal (dorsals separate) (Fig. 138A, B).

(b) Separated from it by a more or less deep notch (dorsals notched) (Fig. 138C, D).

(c) Continuous with first dorsal (dorsals continuous) (Fig. 139B).

9. Extent of second dorsal fin-base ${ }^{1}$ to body length.

(a) Length of base $<1 / 12$ body length (second dorsal perbrevibasic) (Fig. 140A).

(b) Length of base $1 / 12$ to $<1 / 7$ body length (second dorsal brevibasic) (Fig. 140B).

(c) Length of base $1 / 7$ to $<1 / 3$ body length (second dorsal medibasic) (Fig. 140C). 

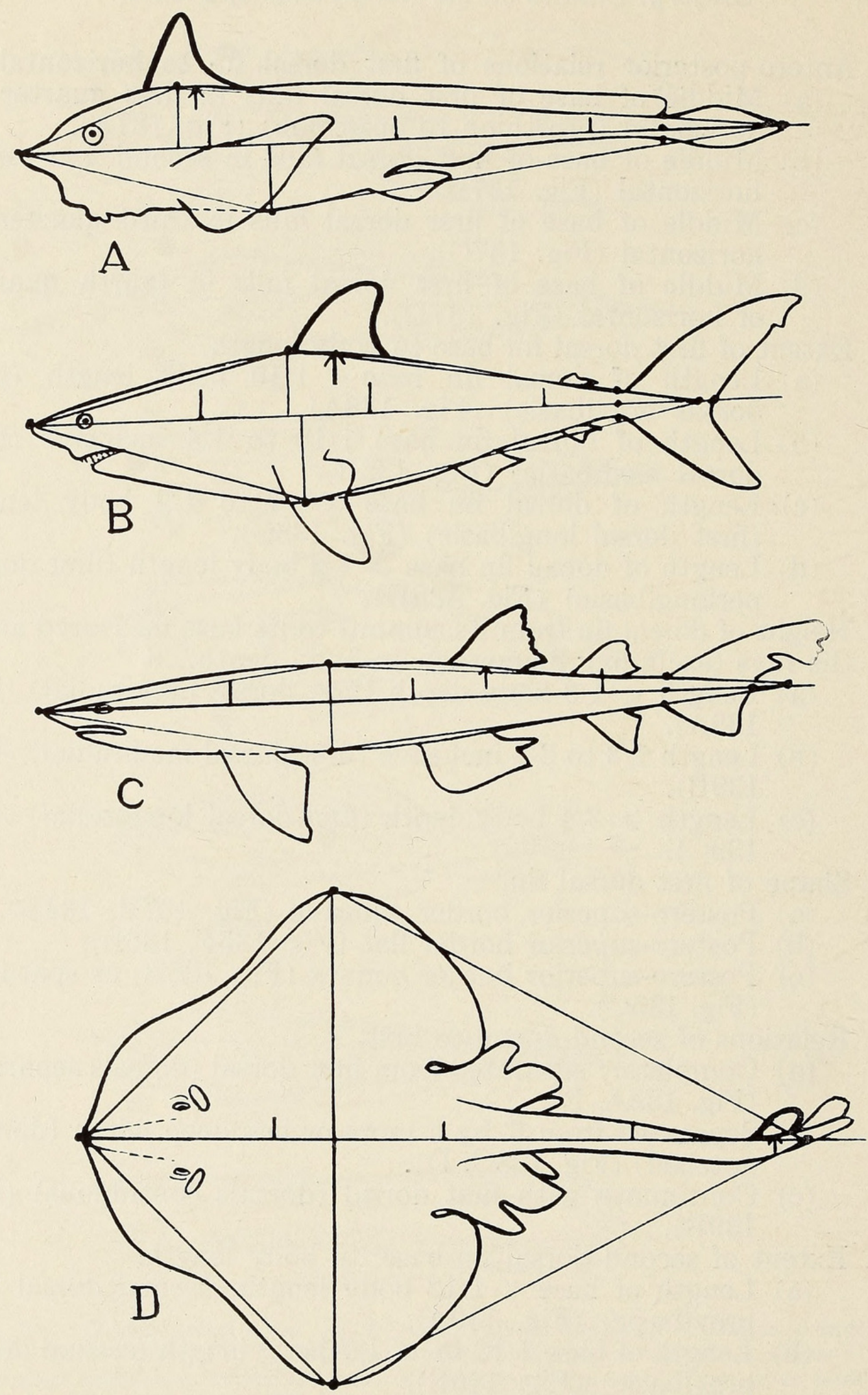

Fig. 137. Varying anteroposterior positions of first dorsal fin. A, Middle of base of first dorsal in first quarter of horizontal (Chimæra affinis); B, in second quarter (Lamna cornubica); C, in third quarter (Catulus uter); D, in fourth quarter (Raja occellata). Outlines after Jordan and Evermann. 

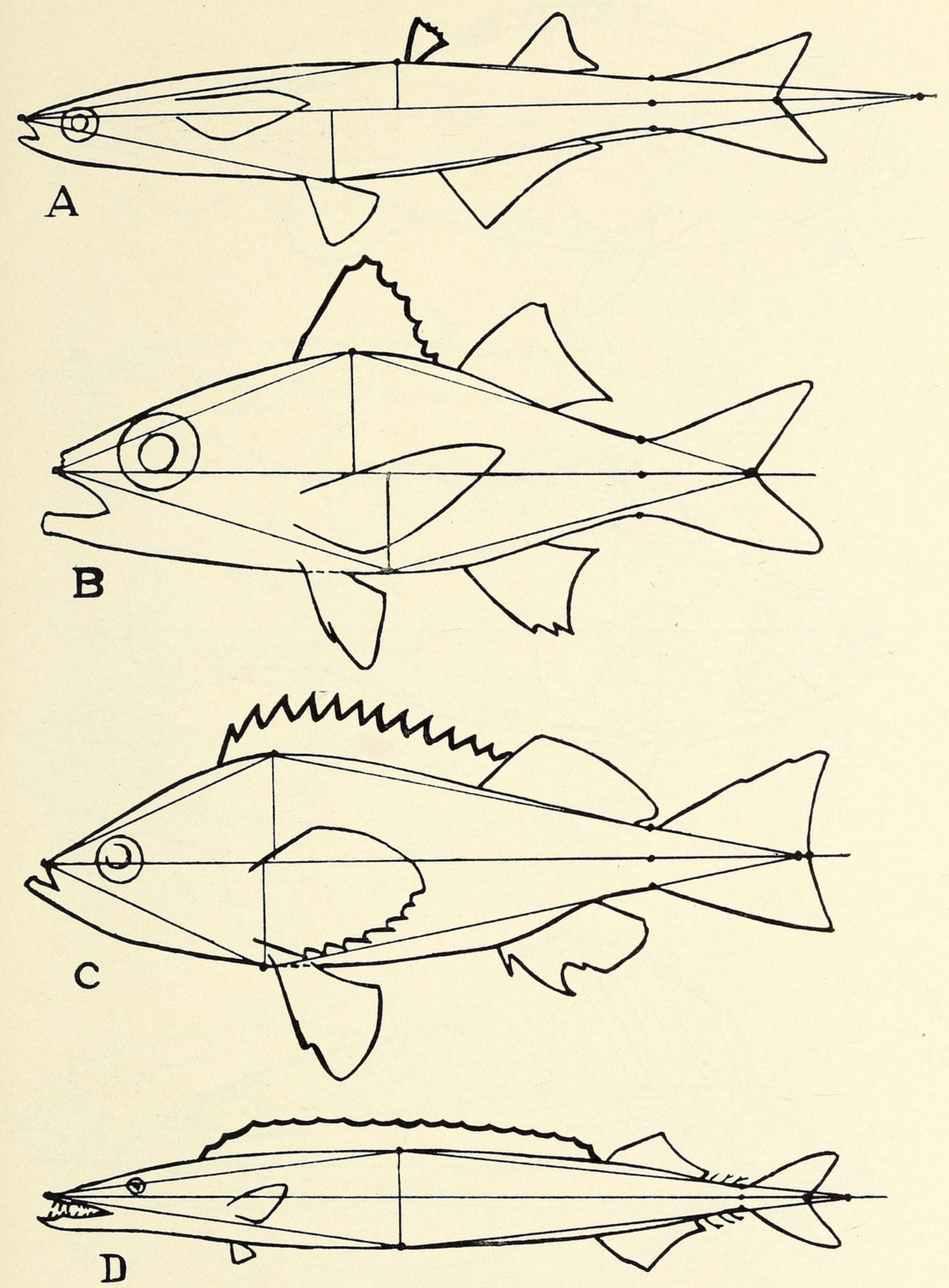

Fig. 138. Extent of first dorsal fin base to body length (prosthion to pygidion). A, First dorsal brevibasic (Kirtlandia vagrans); B, medibasic (Verilus sordidus); C, longibasic (Sebastodes hopkinsi); D, perlongibasic (Escolar violaceus). Outlines after Jordan and Evermann. 

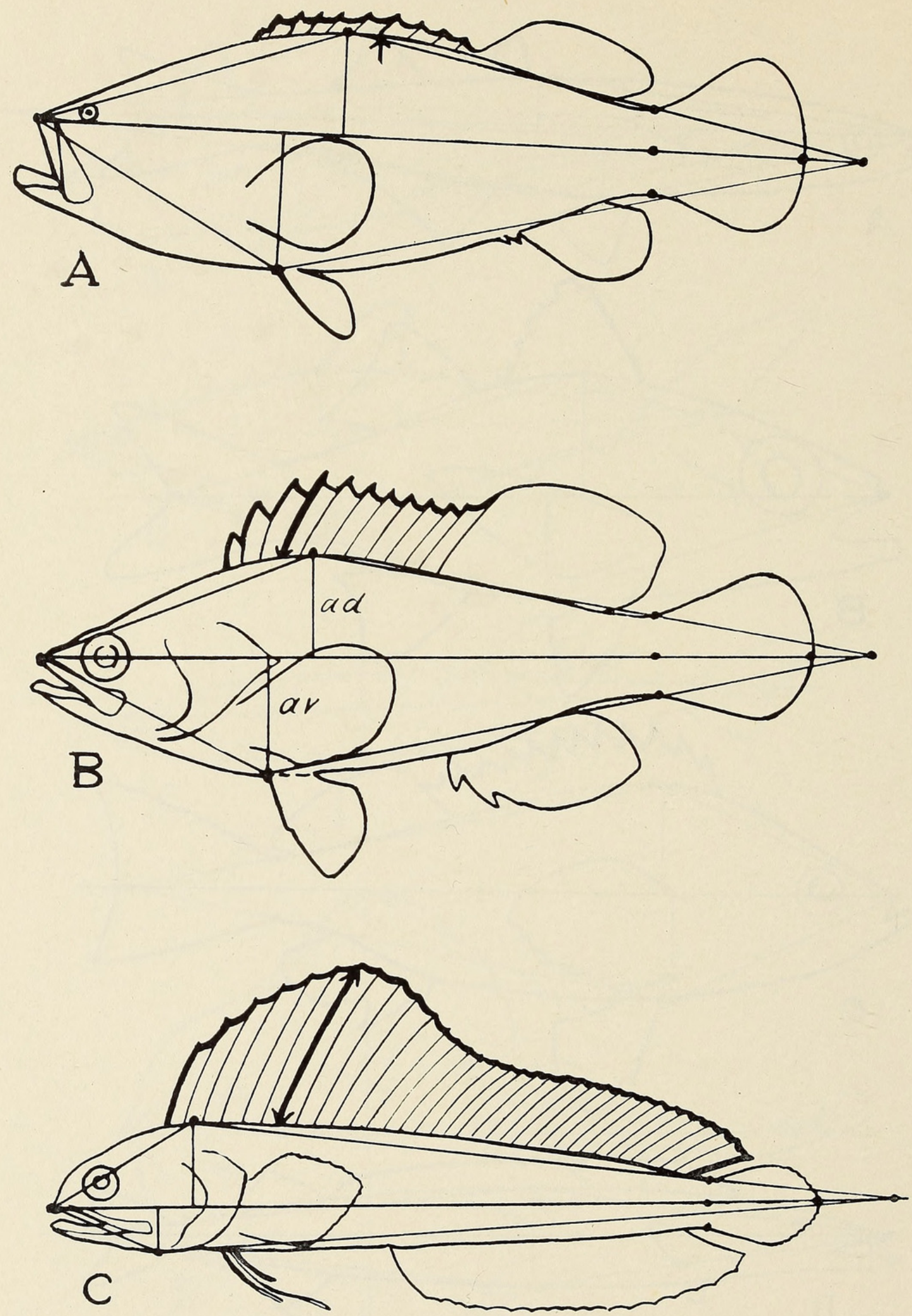

Fig. 139. Height of first dorsal fin to body depth $(a d+a v)$. A, first dorsal breviradial (Promicrops guttatus); B, mediradial (Alphestes afer); C, longiradial (Emblemaria atlantica). Outlines after Jordan and Evermann. 

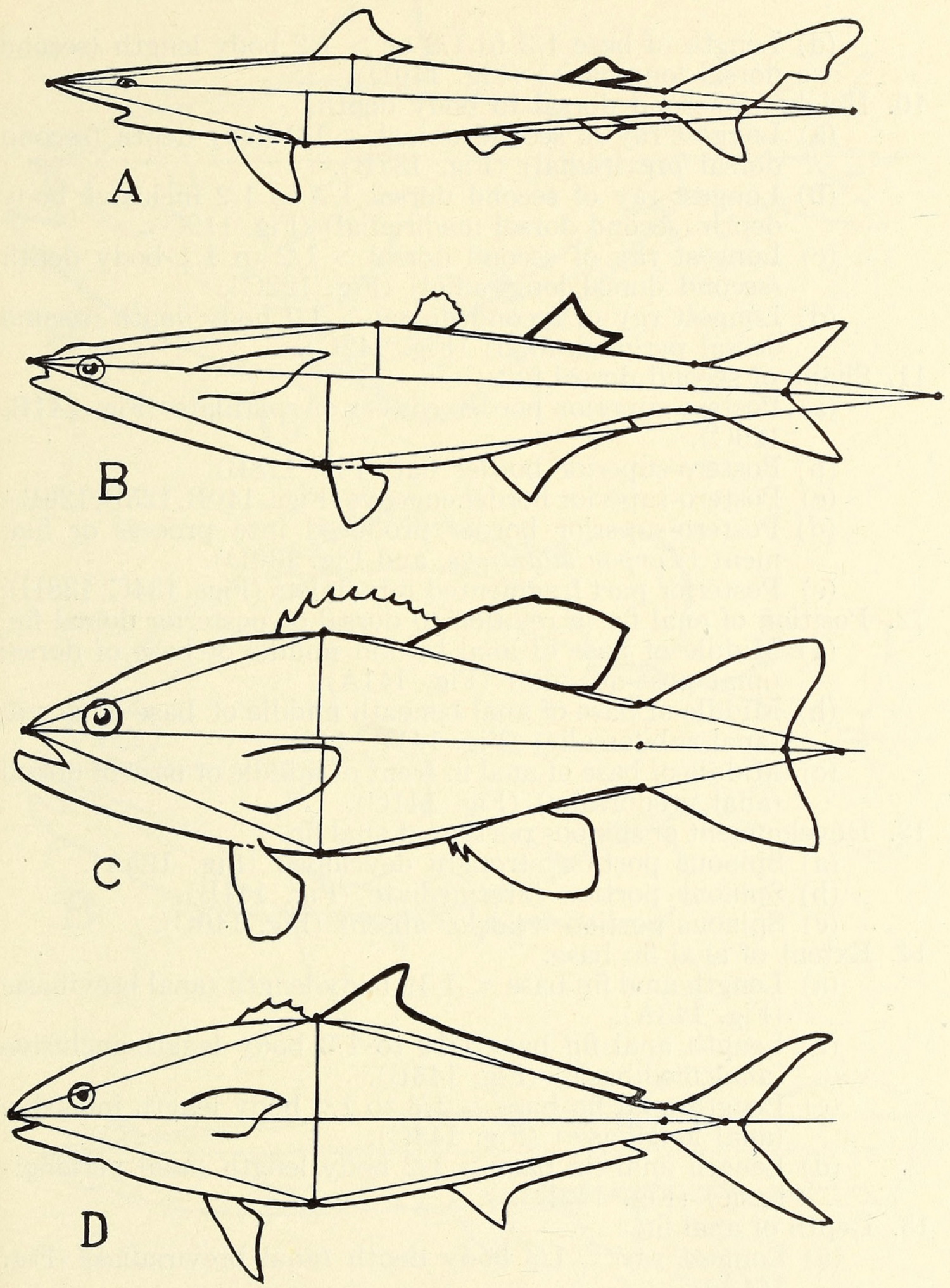

Fig. 140. Extent of second dorsal fin base to body length. A, Second dorsal perbrevibasic (Galeorhinus zygopterus); B, brevibasic (Atherinopsis californiensis); C, medibasic (Micropterus dolomieu); D, longibasic (Seriola dorsalis). Outlines after Jordan and Evermann. 
(d) Length of base $1 / 3$ to $1 / 2$ or $>1 / 2$ body length (second dorsal longibasic) (Fig. 140D).

10. Height of second dorsal to body depth.

(a) Longest ray of second dorsal $<1 / 3$ body depth (second dorsal breviradial) (Fig. 137B).

(b) Longest ray of second dorsal $1 / 3$ to $1 / 2$ inclusive body depth (second dorsal mediradial) (Fig. 119C).

(c) Longest ray of second dorsal $>1 / 2$ to $1 / 1$ body depth (second dorsal longiradial) (Fig. 122C).

(d) Longest ray of second dorsal $>1 / 1$ body depth (second dorsal perlongiradial) (Fig. 142C).

11. Shape of second dorsal fin.

(a) Postero-superior border convex or spatulate (Fig. 141B, 129C).

(b) Postero-superior border flat (Fig. 118B).

(c) Postero-superior border concave (Figs. 140B, 125B, 126B).

(d) Postero-superior border produced into process or filament (Tarpon atlanticus, and Fig. 130D).

(e) Posterior part fragmented into finlets (Figs. 134C, 138D):

12. Position of anal fin in relation to dorsal or posterior dorsal fin.

(a) Middle of base of anal behind middle of base of dorsal (anal post-dorsalic) (Fig. 141A).

(b) Middle of base of anal beneath middle of base of dorsal (anal subdorsalic) (Fig. 141B, 142).

(c) Middle of base of anal in front of middle of base of dorsal (anal predorsalic) (Fig. 141C).

13. Development of spinous portion of anal fin.

(a) Spinous portion strongly developed (Fig. 125A).

(b) Spinous portion intermediate (Fig. 141B).

(c) Spinous portion weak or absent (Fig. 140C).

14. Extent of anal fin base.

(a) Length anal fin base $<1 / 10$ body length (anal brevibasic (Fig. 143A).

(b) Length anal fin base $1 / 10$ to $1 / 3$ body length inclusive (anal medibasic) (Fig. 143B).

(c) Length anal fin base $>1 / 3$ to $1 / 2$ body length inclusive (anal longibasic) (Fig. 143C).

(d) Length anal fin base $>1 / 2$ body length (anal perlongibasic) (Fig. 143D).

15. Depth of anal fin.

(a) Longest ray $<1 / 3$ body depth (anal breviradial) (Fig. $144 \mathrm{~A}$ )

(b) Longest ray $1 / 3$ to $1 / 2$ body depth (anal mediradial) (Fig. 144B).

(c) Longest ray $>1 / 2$ to $1 / 1$ body depth (anal longiradial) (Fig. 144C). 

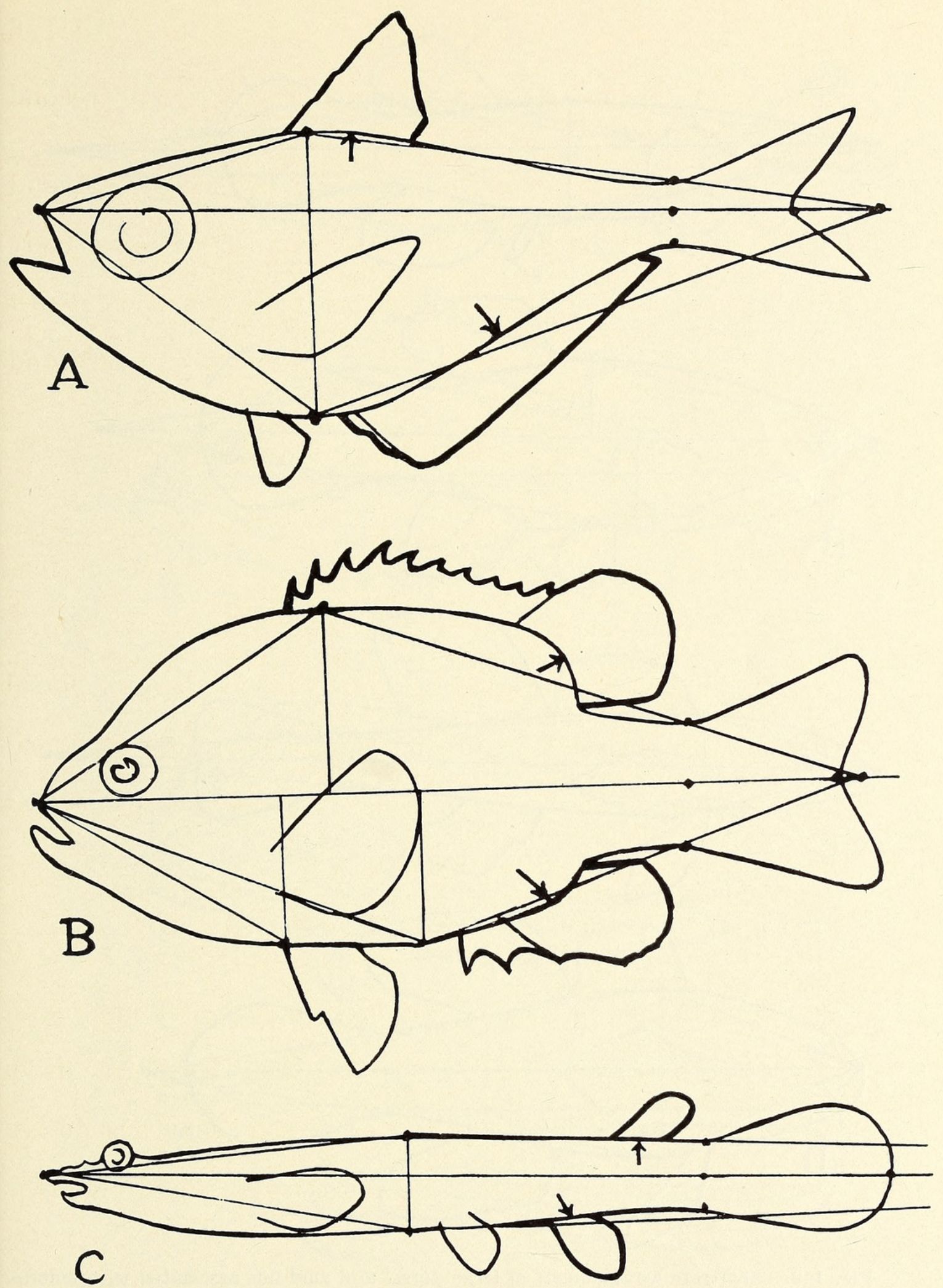

Fig. 141. Varying anteroposterior relations of dorsal and anal fins. A, Anal postdorsalic (Pempheris mulleri); B, sudborsalic (Lepomis auritus); C, predorsalic (Anableps dovii). Outlines after Jordan and Evermann. 

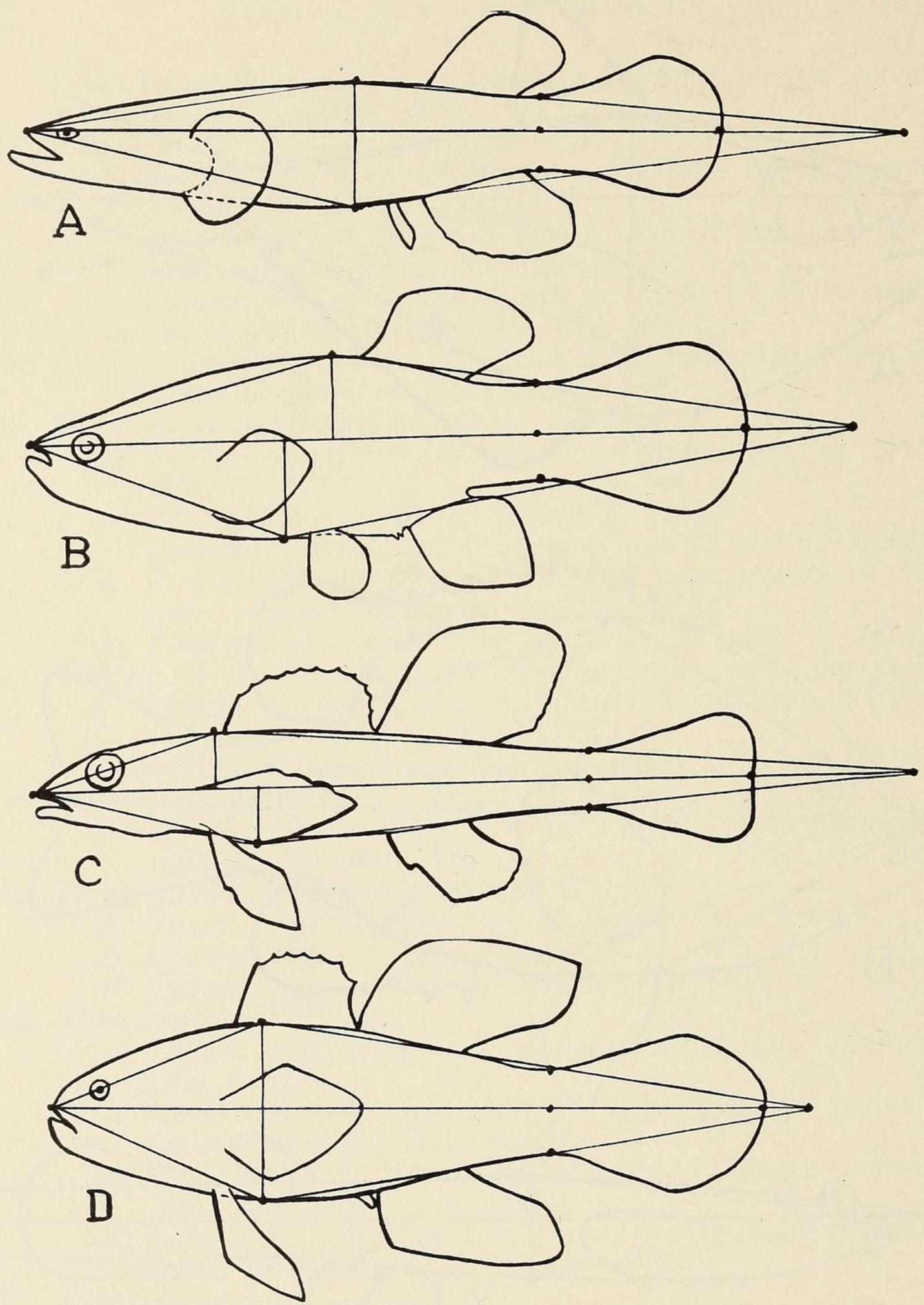

Fig. 142. Sagittate arrangement of large dorsal and anal fins associated with macropygidial macrocercal convex homocercal tails and (usually) with low foreheads. Quick darting forms. A, Dallia pectoralis; B, Fundulus heteroclitus; C, Etheostoma cinereum; D, Dormitator maculatus. Outlines after Jordan and Evermann. 

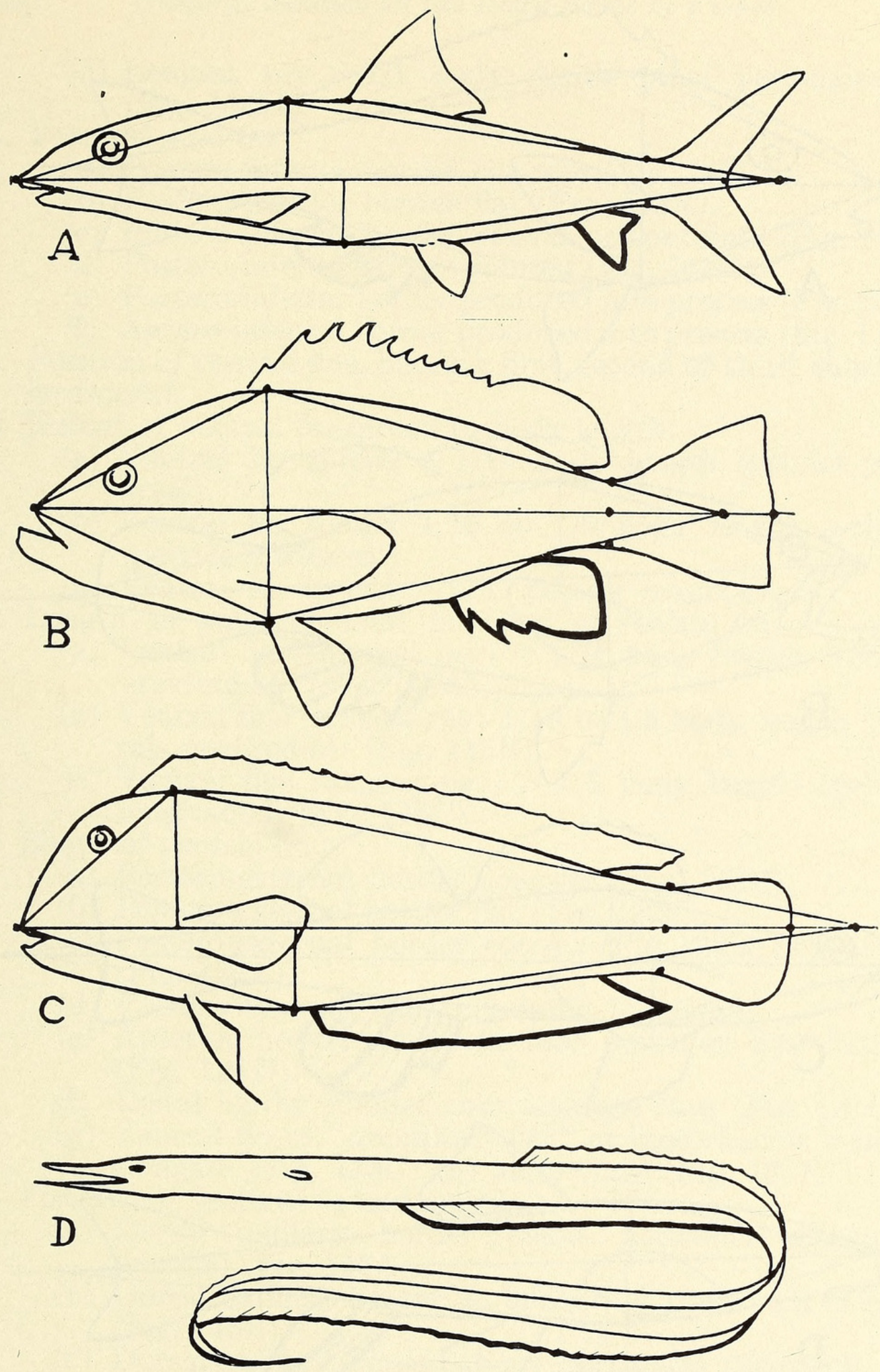

Fig. 143. Varying lengths of anal fin base to body length (Pp). A, Anal brevibasic (Albula vulpes); B, medibasic (Epinephalus drummond-hayi); C, Iongibasic (Xyrichthys psittacus); D, perlongibasic (Serrivomer beanii). Outlines after Jordan and Evermann. 

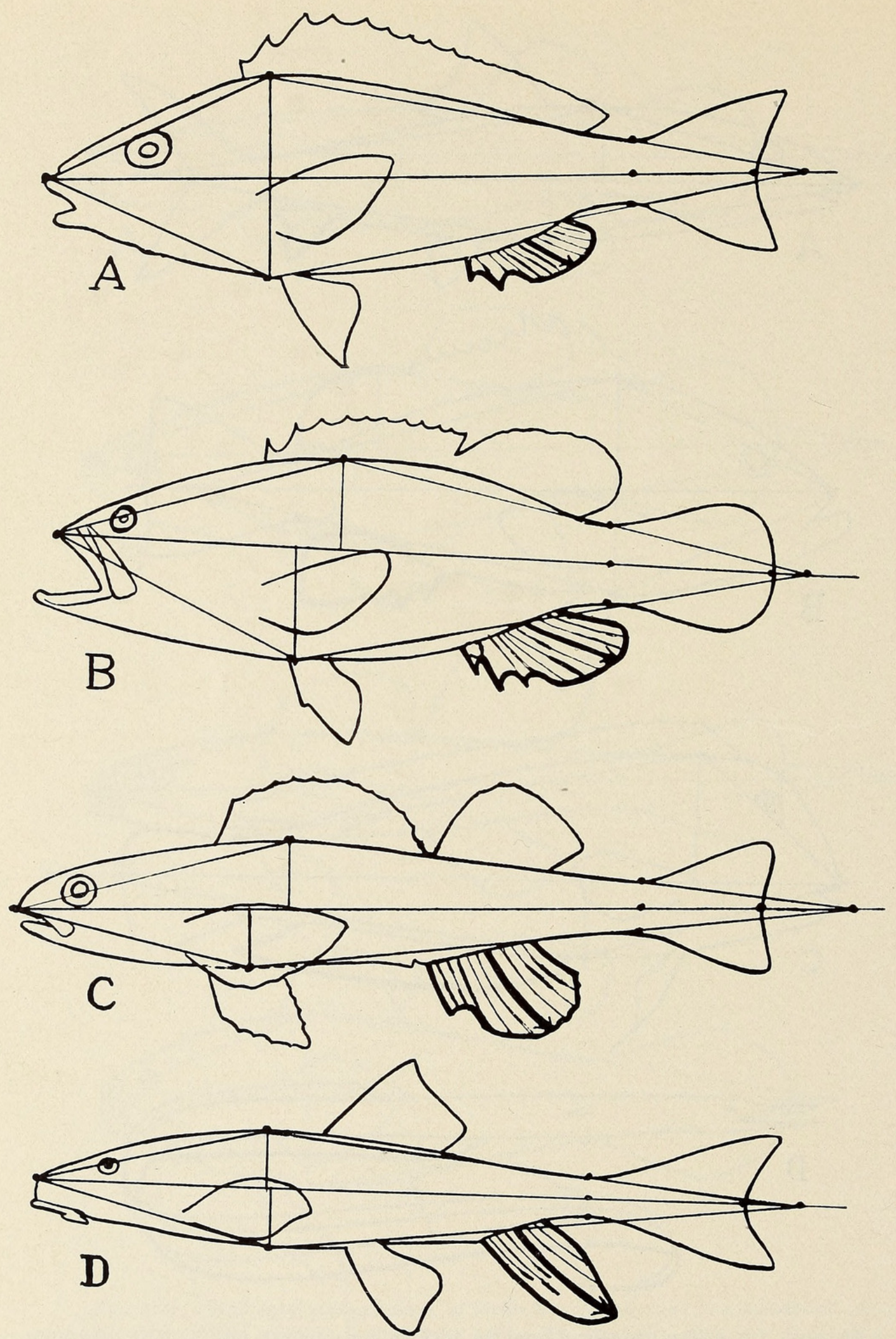

Fig. 144. Varying depth of anal fin to body depth (ad $+a v)$. A, Anal breviradial (Orthopristis reddingi); B, mediradial (Epinephalus striatus); C, longiradial (Hadropterus evides); D, perlongiradial (Catostomus latipinnis). Outlines after Jordan and Evermann. 
(d) Longest ray $>1 / 1$ body depth (anal perlongiradial) (Fig. 144D).

16. Form of anal fin.

(a) Postero-inferior border concave (Fig. 145C).

(b) Postero-inferior border flat (Fig. 145A).

(c) Postero-inferior border convex or spatulate (Fig. 144B).

(d) Postero-inferior border pointed (Fig. 144D).

(e) Postero-inferior border produced into process (Fig. 126B).

(f) Antero-inferior border produced into process (Fig. 119C).

17. Position of ventral fins, beneath first, second or third quarter of horizontal.

18. Extent of ventral fin-spread to body length.

(a) Ventral fin spread $<1 / 10$ body length (pelvics parviareal).

(b) Ventral fin spread $1 / 10$ to $1 / 6$ body length inclusive (pelvics mediareal).

(c) Ventral fin spread $>1 / 6$ (pelvics magniareal).

19. Length, or proximo-distal diameter, of ventral fin.

(a) Ventral fins (longest ray) $<1 / 10$ body length (ventrals breviradial) (Fig. 145A).

(b) Ventral fins (longest ray) $1 / 10$ to $1 / 5$ body length (ventrals mediradial) (Fig. 145B).

(c) Ventral fins (longest ray) $>1 / 5$ body length (ventrals longiradial) (Fig. 145C).

20. Shape of ventral fin.

(a) Postero-external border concave (Fig. 126B).

(b) Postero-external border flat (Fig. 122C).

(c) Postero-external border convex (Fig. 122B) or spatulate (Fig. 122A).

(d) Postero-external border pointed in middle.

(e) Anterior border produced into point or into filament (Fig. 124D).

(f) Distal border divided into separate rays (Fig. 121C).

(g) Ventral fin of "archipterygial" or mesorhachic type (a) elongate (Fig. 133C) ( $\beta$ ) abbreviate (Fig. 133E).

21. Position of pectoral to horizontal.

(a) Dorsal axillary border below horizontal (pectorals inferior) (Fig. 146A).

(b) Dorsal axillary border at horizontal (pectorals median) (Fig. 146B).

(c) Dorsal axillary border above horizontal (pectorals superior) (Fig. 146C).

22. Size of pectoral fin-spread to maximum body depth.

(a) Pectoral fin-spread $<1 / 3$ body depth (pectoral parviareal).

(b) Pectoral fin-spread $1 / 3$ to $1 / 2$ body depth (pectoral mediareal).

(c) Pectoral fin-spread $>1 / 2$ body depth (pectoral latiareal). 
23. Length of pectorals to body length.

(a) Longest ray $<1 / 6$ body length (pectorals breviradial) (Fig. 147A).

(b) Longest ray $1 / 6$ to $1 / 3$ body length inclusive (pectorals mediradial) (Fig. 147B).

(c) Longest ray $>1 / 3$ to $1 / 2$ body length inclusive (pectorals longiradial) (Fig. 147C).
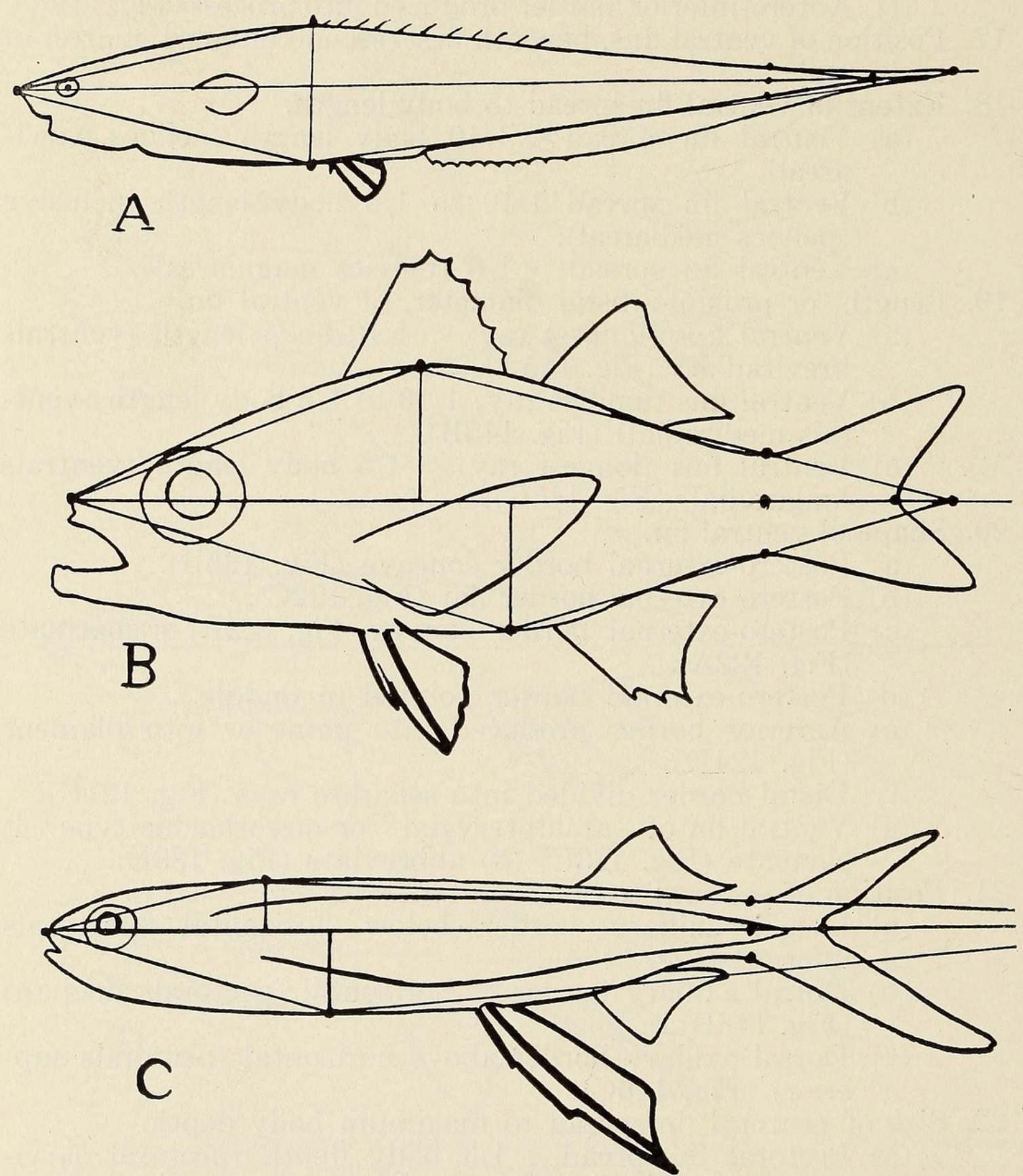

Fig. 145. Varying length of ventrals. A, Ventrals breviradial (Notacanthus analis); B, mediradial (Verilus sordidus); C, longiradial (Exonautes rondeletii). Outlines after Jordan and Evermann. 
(d) Longest ray $>1 / 2$ body length (pectorals perlongiradial) (Fig. 147D).

24. Form of pectorals.

(a) Pectorals concave (Fig. 130B) or truncate (Fig. 130C).

(b) Pectorals spatulate or rounded (Fig. 147A, Fig. 123B).

(c) Pectorals intermediate to pointed (Fig. 147B).

(d) Pectorals falcate (Fig. 147C).
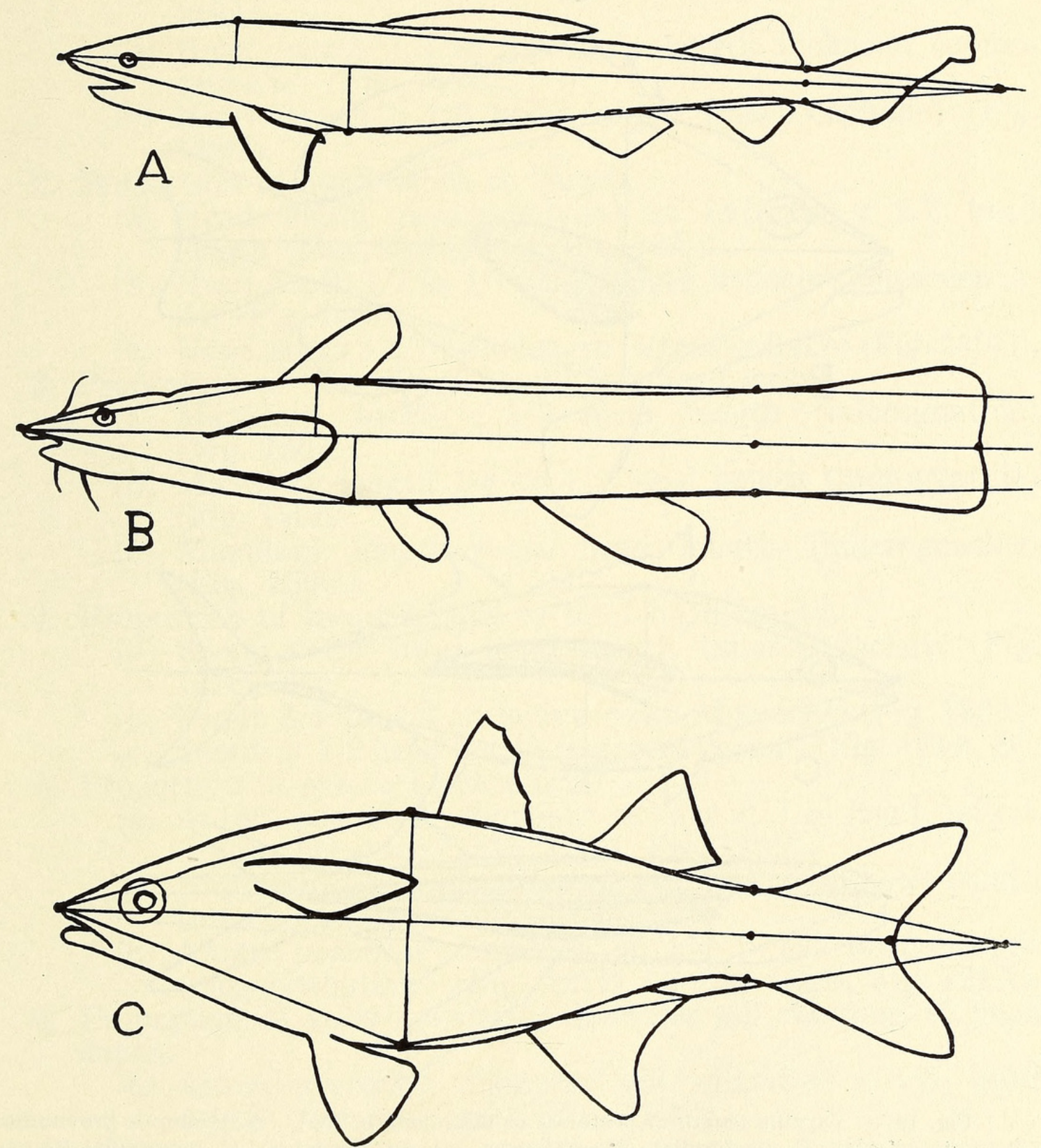

Fig. 146. Varying relations of the pectoral fins to the horizontal. A, Pectorals inferior (Pseudotriakis microdon); B, median (Schilbeodes insignis); C, superior (Chænomugil proboscideus). Outlines after Jordan and Evermann. 

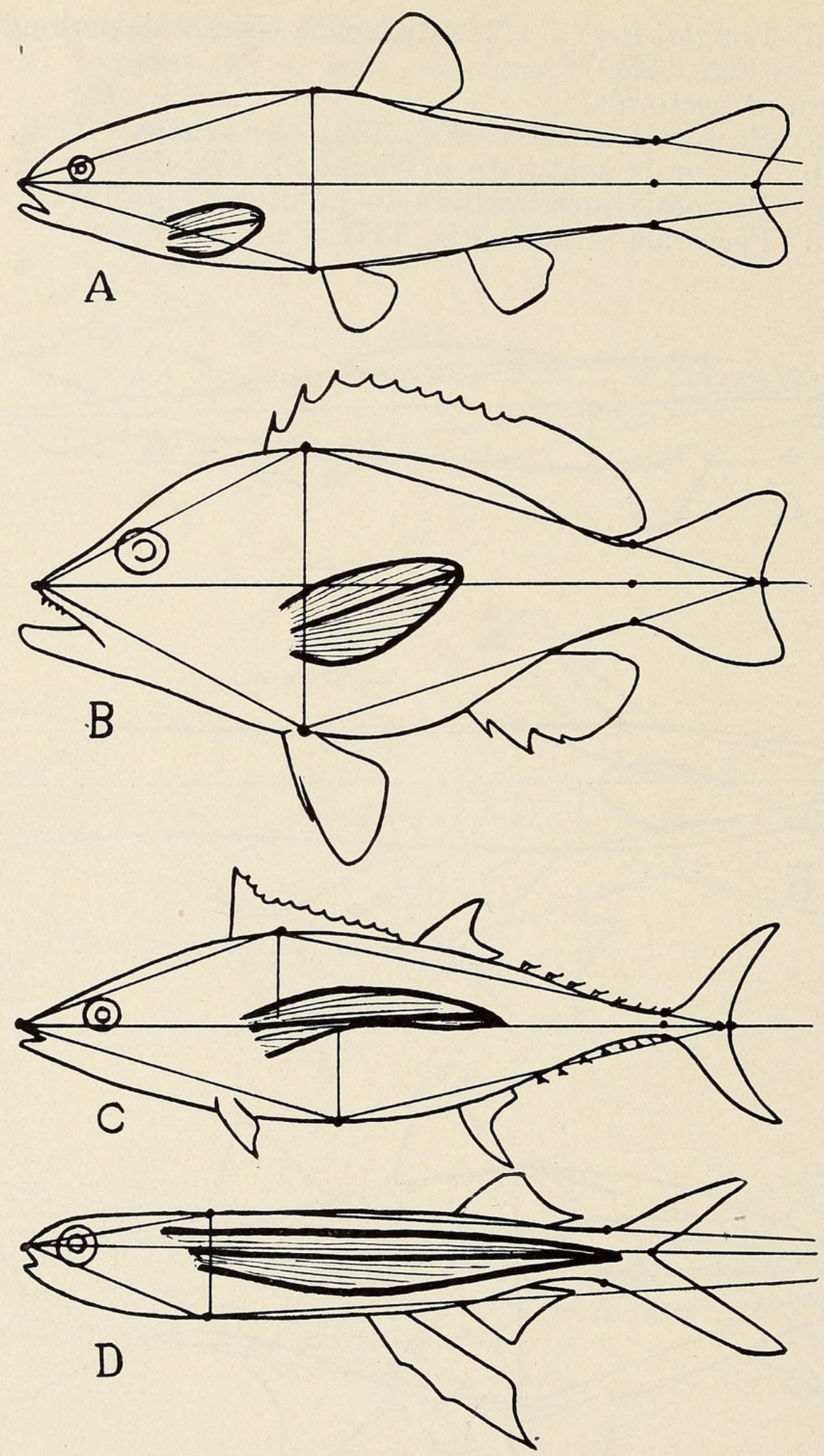

Fig. 147. Varying length of pectorals to body length (Pp). A, Pectorals breviradial (Notropis aztecus); B, mediradial (Hypoplectrus unicolor nigricans); C, longiradial (Germo alalunga); D, perlongiradial (Excnautes rondeletii). Outlines after Jordan and Evermann. 
(e) Pectorals "archipterygial" or mesorhachic (Fig. 133). (a) elongate (Fig. 133A).

( $\beta$ ) abbreviate (Fig. 133E).

(f) Pectorals batoid (Fig. 132).

(g) Pectorals more or less subdivided distally into long rays or filaments (Polynemidæ, Triglidæ, Bathypterois).

III. Variable proportions of the head and its parts.

1. Proportion of head length to body length.

(a) Head length $<1 / 5$ body length (microcephalic) (Fig. $148 \mathrm{~A}$ ).

(b) Head length $1 / 5$ to $1 / 3$ body length inclusive (nomocephalic) (Fig. 148B).

(c) Head length $>1 / 3$ body length (macrocephalic) (Fig. 148C).

2. Proportion of head depth to length.

(a) Head depth (supraoccipital to isthmus) $<1 / 2$ head length (platycephalic) (Fig. 149A).

(b) Head depth $1 / 2$ to $1 / 1$ head length inclusive (mesocephalic) (Fig. 149B).

(c) Head depth $>1 / 1$ head length (hypsicephalic) (Fig. 149C).

3. Proportion of "maxillary length" to head length.

(a) Maxillary length $<1 / 3$ head length (micrognathic) (Fig. 150A).

(b) Maxillary length $1 / 3$ to $1 / 2$ head length (mesognathic) (Fig. 150B).

(c) Maxillary length $>1 / 2$ head length (macrognathic) (Fig. 150C).

4. Proportion of snout length to total head length.

(a) Snout $<1 / 4$ total head length (microrhynchal) (Fig. $151 \mathrm{C}, \mathrm{D})$.

(b) Snout $1 / 4$ to $1 / 2$ inclusive (nomorhynchal) (Fig. 152A).

(c) Snout $>1 / 2$ head length (macrorhynchal) (Fig. 151A, B).

5. Proportion of eye to head length.

(a) Antero-posterior diameter of eye $<1 / 5$ head length (microphthalmic) (Fig. 126B, Fig. 119B).

(b) Antero-posterior diameter of eye $1 / 5$ to $1 / 3$ head length (mesophthalmic) (Fig. 137C).

(c) Antero-posterior diameter of eye $>1 / 3$ head length (megophthalmic) (Fig. 127B, C, Fig. 123B, Fig. 121A).

6. Proportion of antero-posterior diameter gill chamber to head depth.

(a) Antero-posterior diameter gill chamber ${ }^{1}<1 / 3$ head depth$^{2}$ (microcameral) (Fig. 152C).

1 Taken from the anterior border of the preoperculum to the posterior border of the operculum, along the horizontal.

2 Supraoccipital to isthmus. 

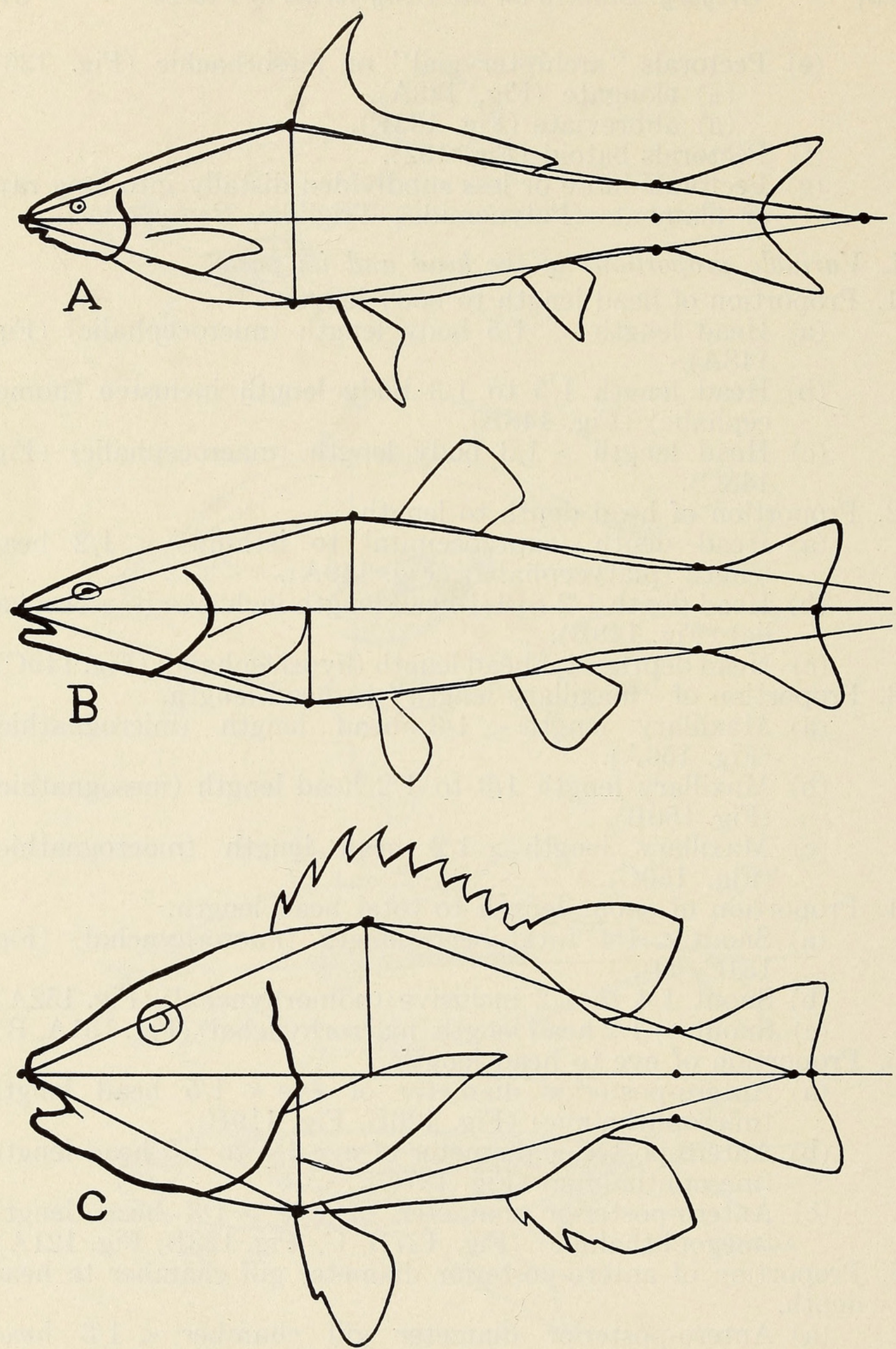

Fig. 148. Varying proportions of head length to body length. A, Microcephalic (Cycleptus elongatus); B, nomocephalic (Semotilus atromaculatus); C. macrocephalic (Hoplopagrus guntheri). Outlines after Jordan and Evermann. 

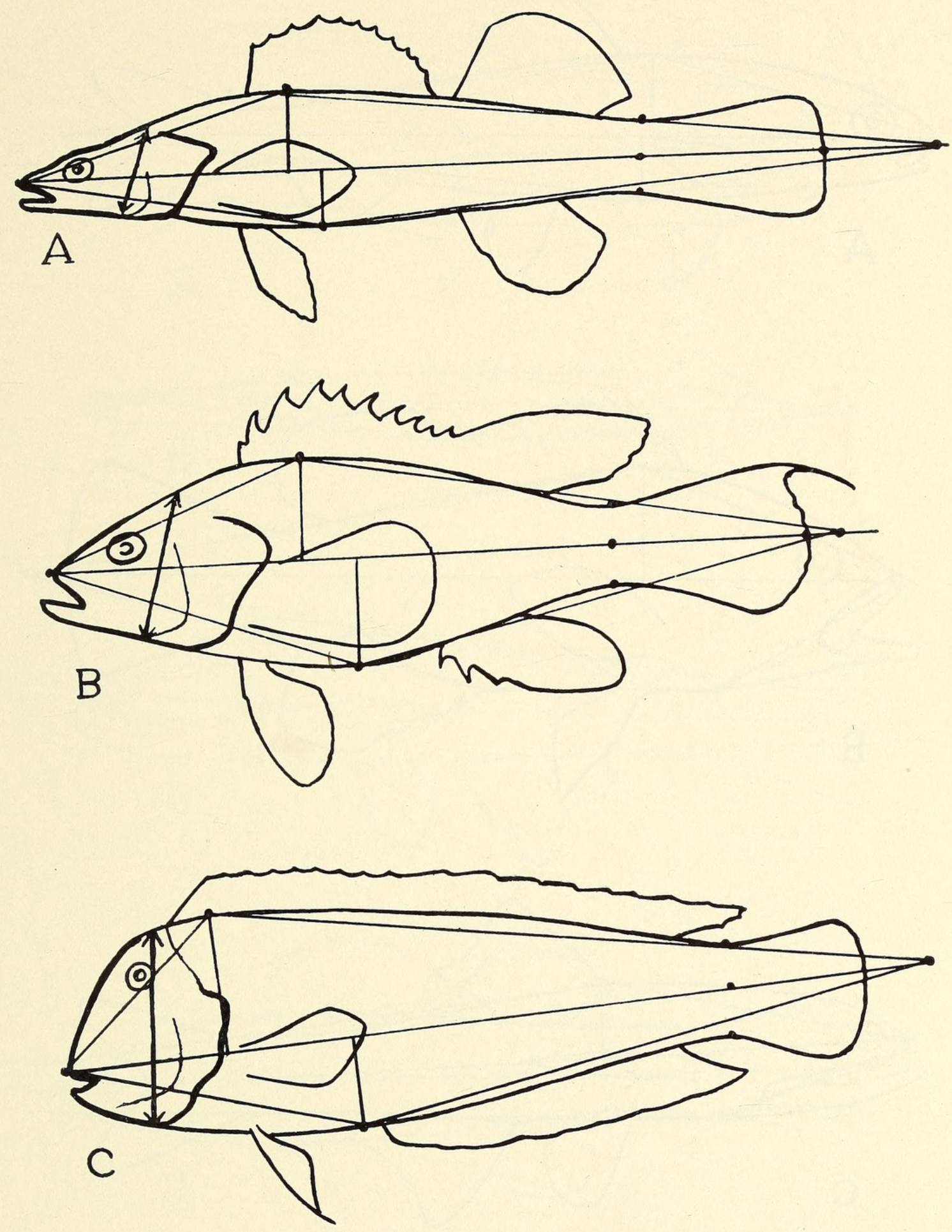

Fig. 149. Varying head depth to head length. A, Platycephalic (Hypohomus spilotus) ; B, mesocephalic (Paralabrax humeralis); C, hypsicephalic (Xyricthys psittacus). Outlines after Jordan and Evermann. 

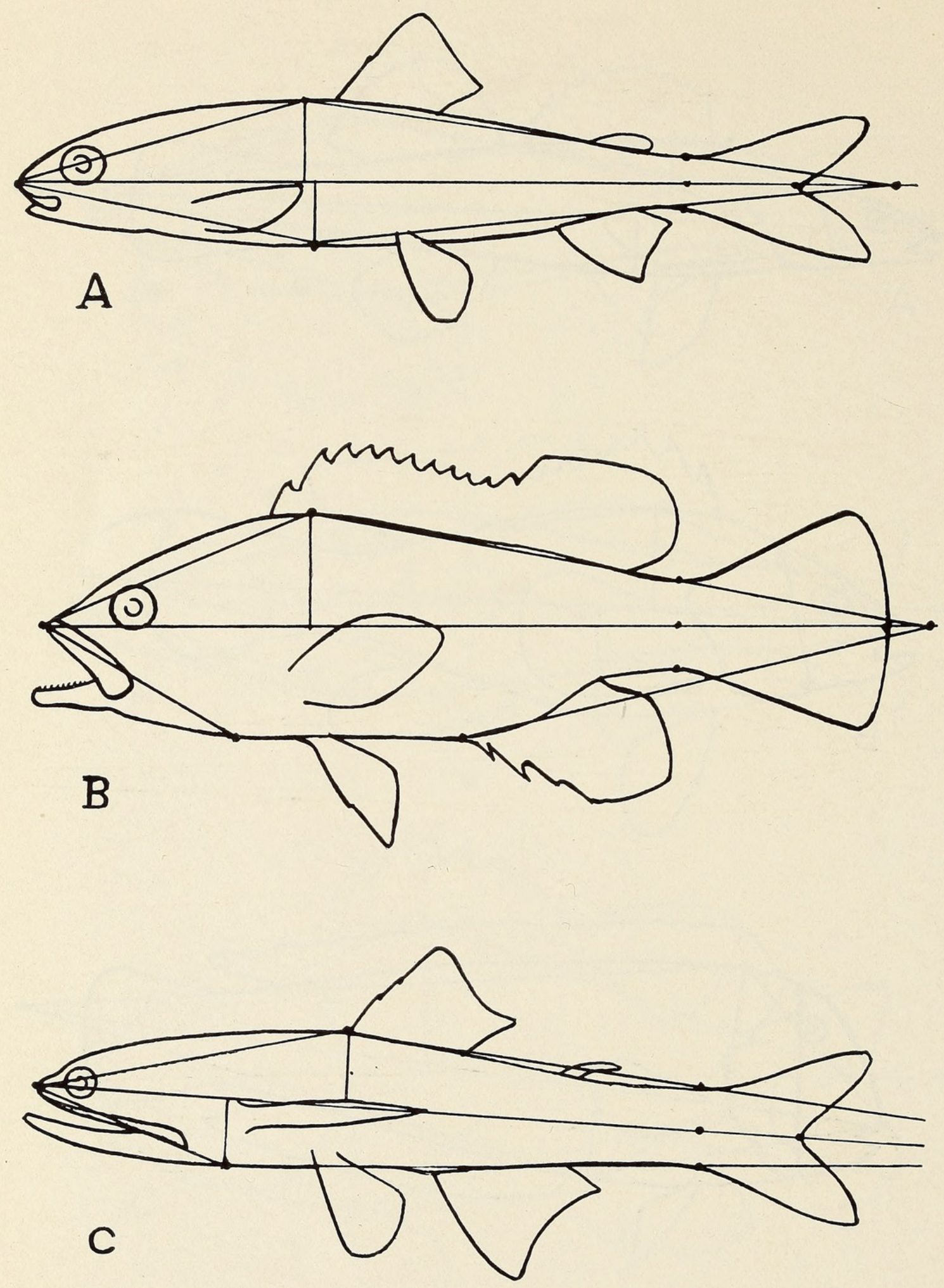

Fig. 150. Varying "maxillary length" to head length. A, micrognathic (Coregonus williamsoni); B, mesognathic (Mycteroperca boulengeri); C, macrognathic (Lampanyctus crocodilus). Outlines after Jordan and Evermann. 

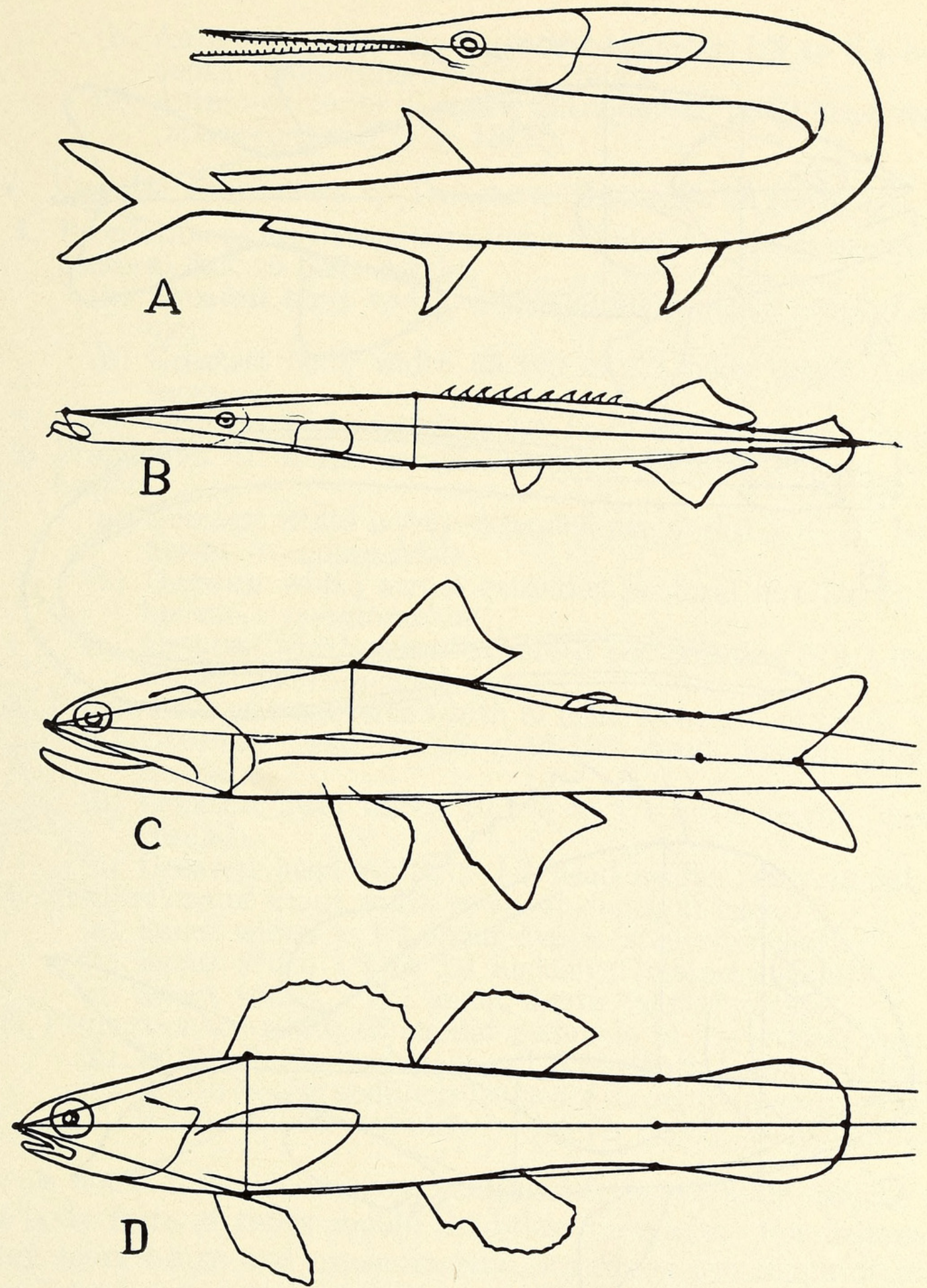

Fig. 151. Varying combinations of different snout lengths and upper jaw length. Long, intermediate or short snouts may be combined with long, intermediate or short jaws, the nine possible combinations all being realized in different fishes. A, Snout long, jaw long (Tylosurus acus); B, snout long, jaw short (Aulorhynchus flavidus); C, snout short, jaw long (Lampanyctus crocodilus); D, snout short, jaw short (Copelandellus quiescens). Outlines after Jordan and Evermann. 

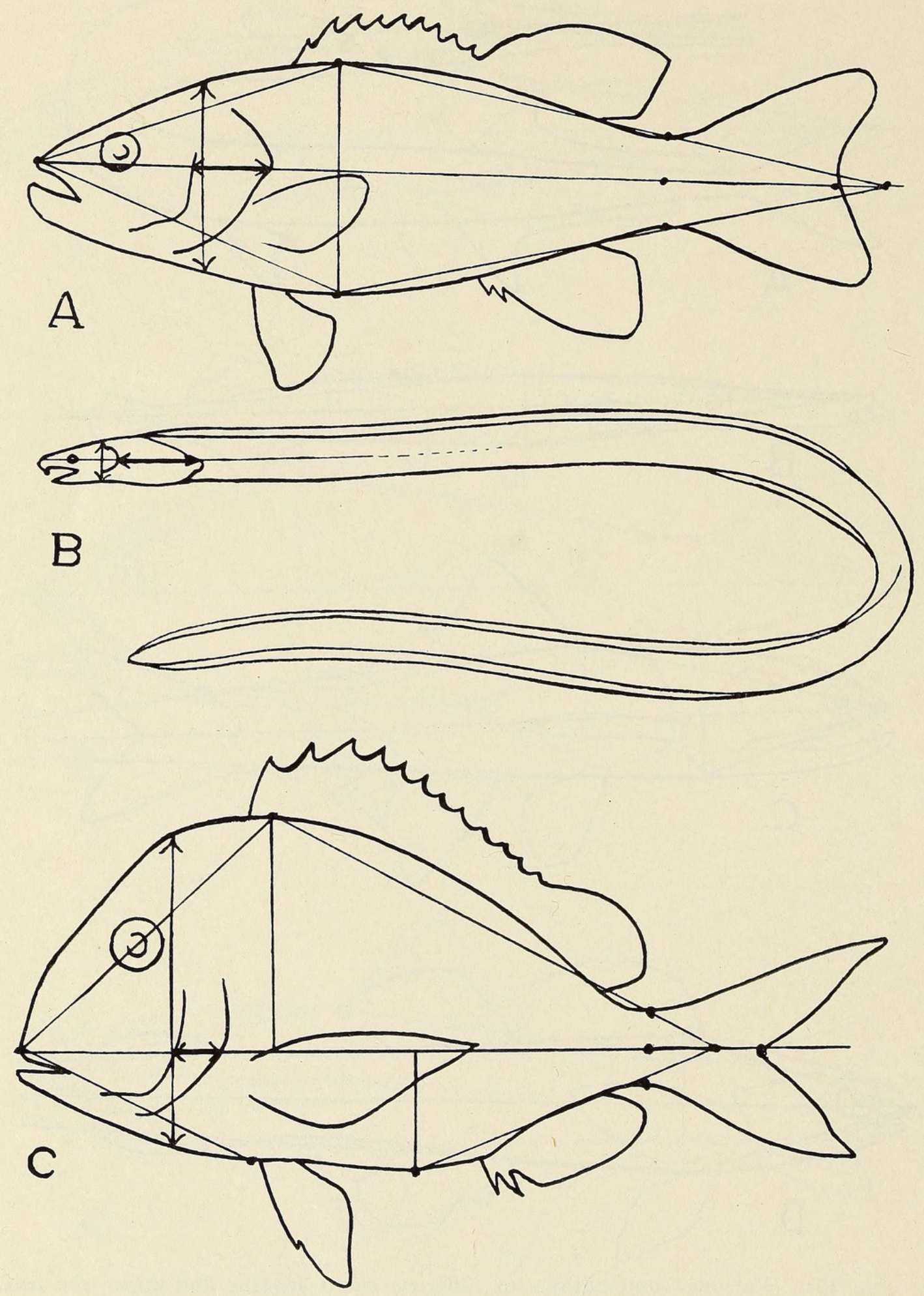

Fig. 152. Varying lengths of branchial chamber to head depth. A, mesocameral (Micropterus dolomieu); B, macrocameral (Bascanichthys scuticaris); C, microcameral (Calamus proridens). Outlines after Jordan and Evermann. 
(b) Antero-posterior diameter gill chamber $1 / 3$ to $3 / 4$ head depth (mesocameral) (Fig. 152A).

(c) Antero-posterior diameter gill chamber $>3 / 4$ head depth (macrocameral) (Fig. 152B).

IV. Variable Proportions of Transverse Diameters to Heights.

1. Proportion of maximum transverse diameter of body, excluding pectoral fins, to body height.

(a) Greatest body width $<45 / 100$ body depth (stenothoracic).

(b) Greatest body width $45 / 100$ to $1 / 1$ body depth (mesothoracic).

(c) Greatest body width $>1 / 1$ body depth (eurythoracic).

2. Proportion of width across extended pectoral fins to body height.

(a) Greatest width across extended pectoral fins $<1 / 1$ body height (stenobrachial).

(b) Greatest width across extended pectoral fins $1 / 1$ to $4 / 1$ inclusive (mesobrachial).

(c) Greatest width across extended pectoral fins $>4 / 1$ body height (eurybrachial).

3. Proportions of transverse width of head to height of head.

(a) Greatest head width $<40 / 100$ head height (stenocranial).

(b) Greatest head width $40 / 100$ to $1 / 1$ head height (mesocranial).

(c) Greatest head width $>1 / 1$ head height (eurycranial).

4. Proportions of snout width to snout depth at nares.

(a) Snout width $<1 / 1$ snout depth (stenorhynchal).

(b) Snout width $1 / 1$ to $3 / 1$ inclusive (mesorhynchal).

(c) Snout width $>3 / 1$ snout depth (euryrhynchal).

5. Proportionate width of caudal peduncle to its vertical depth.

(a) Width caudal peduncle $<1 / 3$ its depth (stenopygidial).

(b) Width caudal peduncle $1 / 3$ to $3 / 4$ its depth (mesopygidial).

(c) Width caudal peduncle $>3 / 4$ its depth (eurypygidial).

A much fuller descriptive analysis of the variable factors of the body form of fishes should doubtless be made. For instance, many more terms and measurements describing the shape of successive transverse sections of the body are needed, as well as terms describing the longitudinal sections, together with the diagrams of the sections themselves. But it is hoped that even the incomplete enumeration given above, together with the new terms for describing these variable relations, will facilitate the comparison of different body forms, especially when an attempt is being made to correlate 
morphological differences with different modes of function. In fact a vast field of inquiry is open in many directions. With what mechanical and functional conditions for example are hyperdolichosomatic types associated? What are the advantages of having the anal fins subdorsalic in position? How do hypsisomatic types maintain the upright position? Only by a synthesis of the knowledge of the marine engineer and architect with that of the experimentalist, morphologist, the field observer and the student of phylogeny can satisfactory answers be reached. 


\section{PART II. PRELIMINARY REVIEW OF THE EVOLUTION OF BODY-FORM IN FOSSIL AND RECENT FISHES}

\section{Ostracoderms, Cyclostomes ANd Other LOWLY CHORDATES}

The earliest known adaptive radiation of body form in chordates.The known ostracoderms of the Silurian and Devonian were the last branches of an older adaptive radiation that was already under way in the Ordovician and probably began in the Cambrian. With the possible exception of the Cololepidæ, none of the known ostracoderms could have been ancestral to the later fishes. Nevertheless the group is of extreme interest because it represents a pre-elasmobranch stage of evolution, very probably related to the ancestors of the cyclostomes. Unfortunately little or nothing is known of the body-form of the earliest Ordovician types, but the body-forms of a number of Silurian and Devonian ostracoderms have been accurately restored from excellent material by Rohon, Traquair, Smith Woodward, Kiær and others. The recently published work of Kiær (1924) on the Upper Silurian ostracoderms of Norway has thrown a great light upon the relationships of the entire group ${ }^{1}$.

The three great orders of Ostracoderms. - The order Anaspida includes small fusiform fishes with a downwardly turned tail. These are remotely related to the modern cyclostomes, and like them, are monorhinal, with a median nasal opening, followed by a pineal opening; they also have small round gill openings varying from 6 to 15 in number (Kiær.)

The Cephalaspidomorphi (Osteostraci) have the very broad head covered (except in Ateleaspis) with a continuous shield. The eyes are dorsal on top of the shield whereas in the more primitive Anaspida, they are lateral. The nasal opening is single and behind it is a pineal opening as in the Anaspida.

The order Heterostraci, according to Stensiö's view, is related to the ancestral myxinoids rather than to the elasmobranchs. In the very primitive Cœlolepidæ the depressed body is covered with shark-like placoid scales or denticles, but in the Pteraspidæ the fusiform body is protected by a massive armor or covering of large head

1 The superb monograph by Stensiö on the Norwegian Cephalaspidæ was received after this paper was in page proof. It proves that the Cephalaspidæ were closely related to the lampreys. 
plates without bone cells. Kiær infers that the Heterostraci had paired nostrils and were thus diplorhinal, like the modern elasmobranchs and higher fishes.

The Anaspida.-The Anaspida are of extraordinary interest because they appear to be, on the whole, the most primitive known chordates. The body is fusiform, the chief peculiarity being the downwardly turned tail, the tail fin being epichordal exactly as in the ichthyosaurs, thalattosuchians, etc., and the direct opposite of a heterocercal tail. No exact parallel to this occurs in the higher fishes, but it would seem to be well adapted for a fish that perhaps floated inertly or rested lightly on or near the bottom or made brief cycloidal flights in pursuit of small crustaceans which may have been engulfed in the capacious pharynx. The downwardly turned tail may also have been the chief means of maintaining the stability or upright position of the fish. The pectoral fin spines would be lateral balancers and the dorsal spines would serve as small keel plates. The principal lateral thrusts were from the dorsal tail fin and, to a less extent, from the anal fin, which together may have functioned somewhat like the posteriorly displaced dorsal and anal fins of pike-like fishes.

The Anaspida are also of great interest because they show the oldest known stage in the development of scales, dermal rays and spines. The vertically deep rows of lateral flank scales were separated by horizontal septa that apparently correspond in function, with those of modern fishes. From the general correspondence in direction of the scale rows to those of modern fishes, it seems likely that the myotomes of the Anaspida were likewise bent into Wshaped segments.

It is interesting to find that the anatomical points and axes of reference described in Part I as characteristic of later fishes, are more or less recognizable in the body contours of these most ancient known chordates, which doubtless conformed in similar ways to the requirements of gravitation and to stream-line conditions of pressure and friction.

The Heterostraci.--Among the Heterostraci, Pteraspis, as restored by various authors evidently conforms to normal quadrilaterals in the side, top, bottom and sectional views. Owing to the presence of the hard dorsal and ventral shells and to the apparent absence of dorsal and anal fins, turning movements were probably 
slow. The stream-line contours of the shell would seem to be well adapted for fluviatile life and the strongly developed shell may have served as a protection from impacts against stones in the stream.

Thelodus and Lanarkia are apparently the most primitive of the ray-like Heterostraci, since the body is covered with separate shagreen or placoid scales instead of a more or less continuous shield. As seen from above, the body combines the features of several modern batoids. Thus, they have the unreduced caudal half, and forked heterocercal tail ${ }^{1}$ of the Rhinobatidæ, the rounded anterior end and widely separated eyes of Rhina, the projecting pectoral tips of Aëtobatis. Their quadrilaterals also broadly resemble those of the corresponding modern types, this showing that similar responses to stream line pressures were made on the one hand by the Cœlolepidæ and Drepanaspidæ of the Heterostraci, and on the other hand by the ancestors of the modern rays.

Drepanaspis of this order closely parallels Torpedo in the rounded form of its disk, but contrasts widely with all batoids in its evident inability to undulate the outer border of the disk. It parallels Manta in the great width and toothless condition of the mouth and in the reduction and wide separation of the eyes. The quadrilaterals of all these forms resemble those of their modern analogues.

The Osteostraci.-Cephalaspis and its allies among the Osteostraci present analogies with Limulus in the form of the carapace as well as in the details of their quadrilaterals. Probably all these resemblances indicate similar responses to stream-line conditions.

Principal types of body-form in the ostracoderms and their modern relatives.-The principal types of body forms and fins among the ostracoderms, cyclostomes and other lowly chordates may be named and described as follows:

\section{Class OSTRACODERMI}

\section{Order Anaspida}

Birkenoid: Body fusiform, mesomatic, tail hypobatic and hypocercal (Kiær). A series of dorsal fulcra or ridges, but no dorsal fin. Epichordal tail fin supported by dermal rays. A small anal fin. Pectoral spine or spines. Sides covered with vertically deep rhombic scales, often with peg and socket articulations. Eyes lateral.

${ }_{1}^{1}$ Possibly in this case a reversed heterocercal tail, like that of Anaspida. 
Pharynx capacious, mouth large, terminal, no teeth. Nectonic, fluviatile.

Pharyngolepis has a median mandibular jaw plate opposing a kind of incipient beak. Kiær thinks it was a predatory form. Lasanius, Euphanerops, Pterolepis, etc., present minor modifications of this Birkenoid type.

\section{Order Osteostraci}

Cephalaspidoid: Eurycephalic, head rounded in front, domed, covered with a thin bony shield. Eyes large, dorsal. Body robust, triangular in cross-section, flanks covered with deep scales. Tail heterocercal to diphycercal. Paired pectoral flaps behind cornua of shield. Benthic, fluviatile. Thyestes and Tremataspis show related types of body form.

\section{Order Heterostraci}

Thelodoid (Cœlolepidoid): Eurythoracic, eurycephalic, macrocephalic, tail macrocercal and deeply forked (possibly reversed heterocercal as in Anaspida). Eyes lateral, small. Small pectoral lappets. Body covered with placoid or shagreen denticles. Benthic, fluviatile.

Drepanaspidoid: Essentially as in Thelodus, but two large plates on back, long lateral plates and one median ventral plate. Tail large, with the ventral lobe somewhat stronger than the dorsal lobe. Eyes small lateral, mouth very wide, toothless. Benthic, fluviatile.

Pteraspidoid: Fusiform; rostrum produced, or short and bluntly rounded. Eyes small, lateral. Massive shield of seven plates homologous with those of Drepanaspis. Fluviatile, partly benthic, partly nectonic.

\section{Order Cyclix}

Palæospondyloid: A well developed endocranium and backbone, the former suggesting the skull of cyclostomes, the latter composed of ring-like centra. Body moderately elongate, ending in a large diphycercal tail which is provided with cartilage (?) rays resembling those of cyclostomes.

\section{Order Cyclostomata}

Petromyzontoid: body anguilliform, cylindrical; pectoral and pelvic fins absent. Dorsal, caudal and anal fin supported by cartilaginous rays. Tail diphycercal. Branchial chamber elongate. Probably a secondarily naked derivative of the stem of the Anaspida. The larval form Ammocotes shows evidence of remote relationship with Amphioxus and these two forms are probably the nearest living representatives of the ostracoderms.

Myxinoid: Essentially, as in Petromyzon, but with degenerate median fins and reduced endoskeleton. Semi-parasitic. 


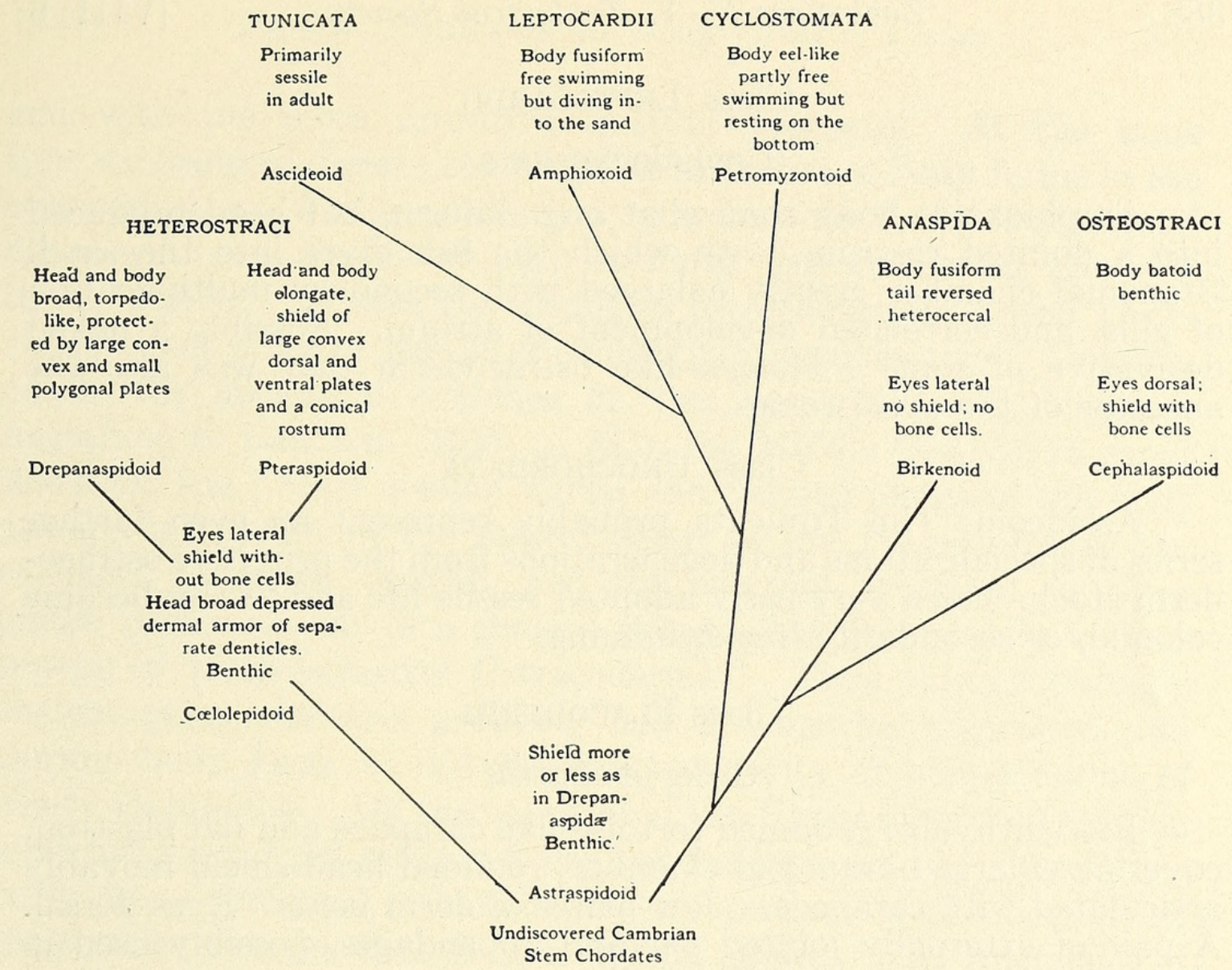

Fig. 153. Adaptive radiation of body form in ostracoderms

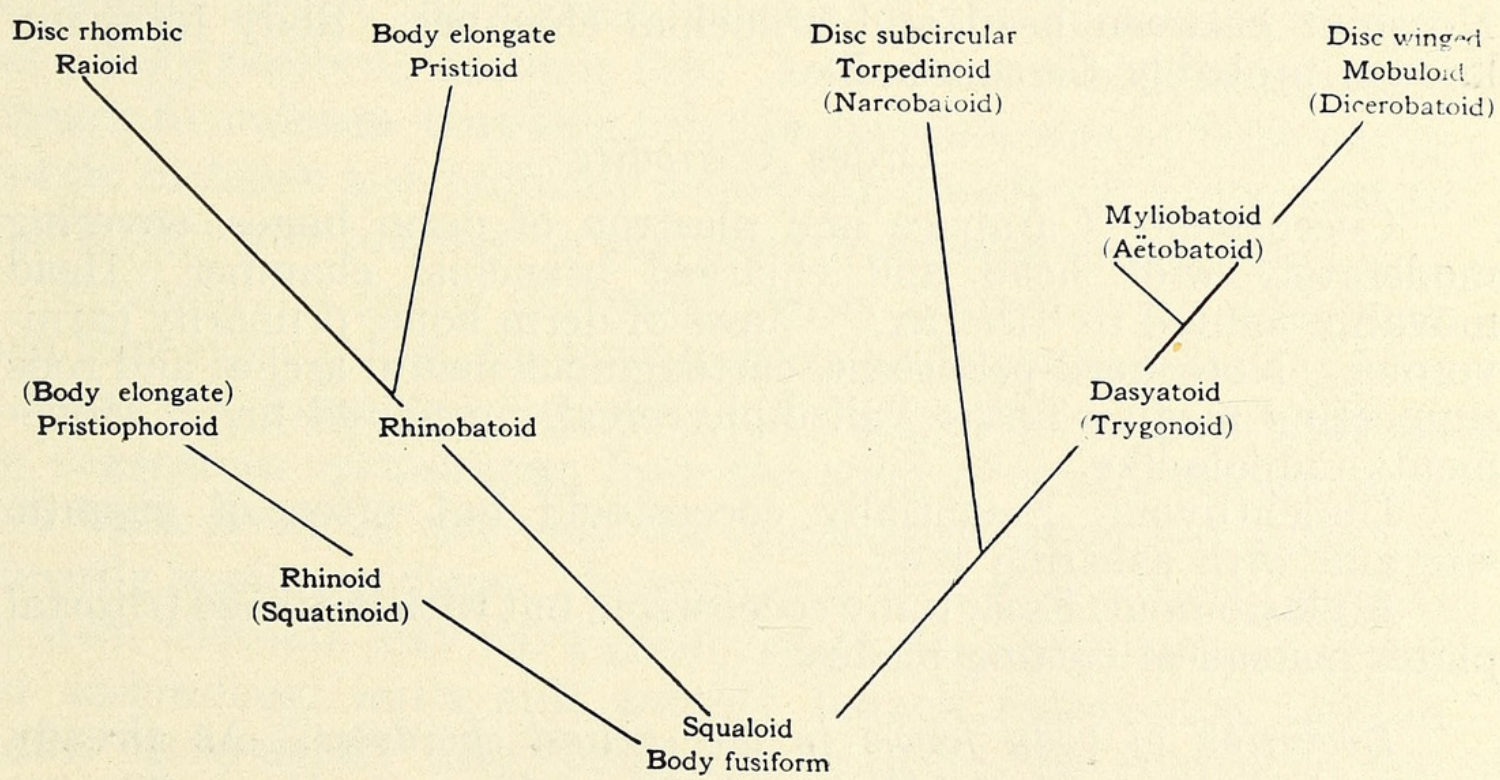

Fig 154. Adaptive radiation of the depressed elasmobranchs 


\section{Class LePTOCARDII}

(Cephalochordata)

Amphioxoid: body somewhat anguilliform, but head produced into a pointed rostrum, with which the fish dives into the sand. Branchial chamber greatly enlarged with secondary multiplication of gills, and correlated development of atrium. Possibly a naked derivative of some Pterolepis-like ostracoderm that was also the ancestor of the cyclostomes.

\section{Class UROCHORDATA}

Ascideoid: The Tunicata probably represent an even further series of specializations and degenerations from the primitive ostracoderm stock, which very early adopted sessile life and finally became colonial, or secondarily free-swimming.

\section{Class Placodermi}

\section{Order Antiarchi}

Pterichthyoid: A domed tortoise-like carapace and flat plastron, covering enlarged branchial chamber; rounded head-shield movably articulated with carapace. Jaw plates of derm bone. Eyes dorsal. A pair of externally jointed pectoral appendages, possibly used in steering. Heterocercal. Fluviatile.

\section{Order Anarthrodira}

Macropetalichthyoid: Head large covered with derm bones. No joint between head and branchial chamber. Body form unknown, probably Coccosteus-like.

\section{Order Arthrodira}

Coccosteoid: Carapace and plastron of derm bones, covering moderately wide head and enlarged branchial chamber. Head movably jointed to "thorax." Jaws of derm bone, primarily carnivorous. Notochord persistent, cartilaginous neural arches and rods supporting median fins. Tail diphycercal, no paired fins. Movements tadpole-like.

Dinichthyoid: Essentially coccosteoid but often of gigantic size and with shearing jaws.

Mylostomoid: Essentially coccosteoid but with flattened tritortal plates instead of cutting blades.

Evolution of body forms in the earliest chordates.-As already noted the recent results of Kiær and of Stensiö, on the Upper Silurian Ostracoderms of Norway bring us a long way nearer to the solution of the interrelationships of the ostracoderm orders with each other 
and with the more primitive existing chordates. At the same time we begin to discern the adaptive radiation of body forms in the ostracoderms. Which came first, the benthic forms with broad depressed head shields or such fusiform free swimming types as the Anaspida? Or was the primitive ostracoderm of Lower Ordovician times more or less intermediate between the two? Unfortunately the geological evidence on this point is hardly decisive. According to Eastman (1917, p. 237), the Middle Ordovician genus Astraspis has "large median dorsal and ventral plates of the body armor constructed in the same fashion as the Psammosteidæ out of fused polygonal tesseræ, and the external ornament of these plates is also similar in a general way to that observed in various genera of Heterostracous Ostracoderms." Thus this exceedingly ancient genus Astrapis probably had a somewhat depressed and benthic body form, as did the great majority of ostracoderms of nearly all families. On the other hand the Upper Silurian Anaspida were not specialized benthic fishes but fusiform, and at least incipiently free-swimming, although possibly resting on the bottom at times, with the aid of their pectoral fin spines. The frequency of an enlarged gill chamber, a high number of gills and a capacious pharynx are all suggestive of forms that at least rested partly on the bottom as do the cyclostomes and Amphioxus. Hence we can hardly accept the current belief that the ancestral chordate was a fully fusiform, nectonic fish. Indeed the prevailing evidence appears to indicate that this fish-like chordate was at least partly benthic in habit and probably somewhat broader in proportion to height than was the case in perfected free-swimming types.

From such a partly depressed, partly bottom-living type, may have been evolved first, the known specialized depressed forms of the Silurian and Devonian, secondly, the anguilliform and more or less degenerate cyclostomes, from the stem of which in turn may have been given off not only the Amphioxus group but even the primarily sessile ascidians. In another direction, the partly depressed stem chordate may have given rise to the testudinate antiarchi and arthrodires, while still another branch represented by the known Heterostraci may, according to Kiær, be related to the diplorhinal stock of the elasmobranchs and higher fishes.

These inferences are far from being idle speculations. There is a wide field of well known embryological evidence for the relatively 


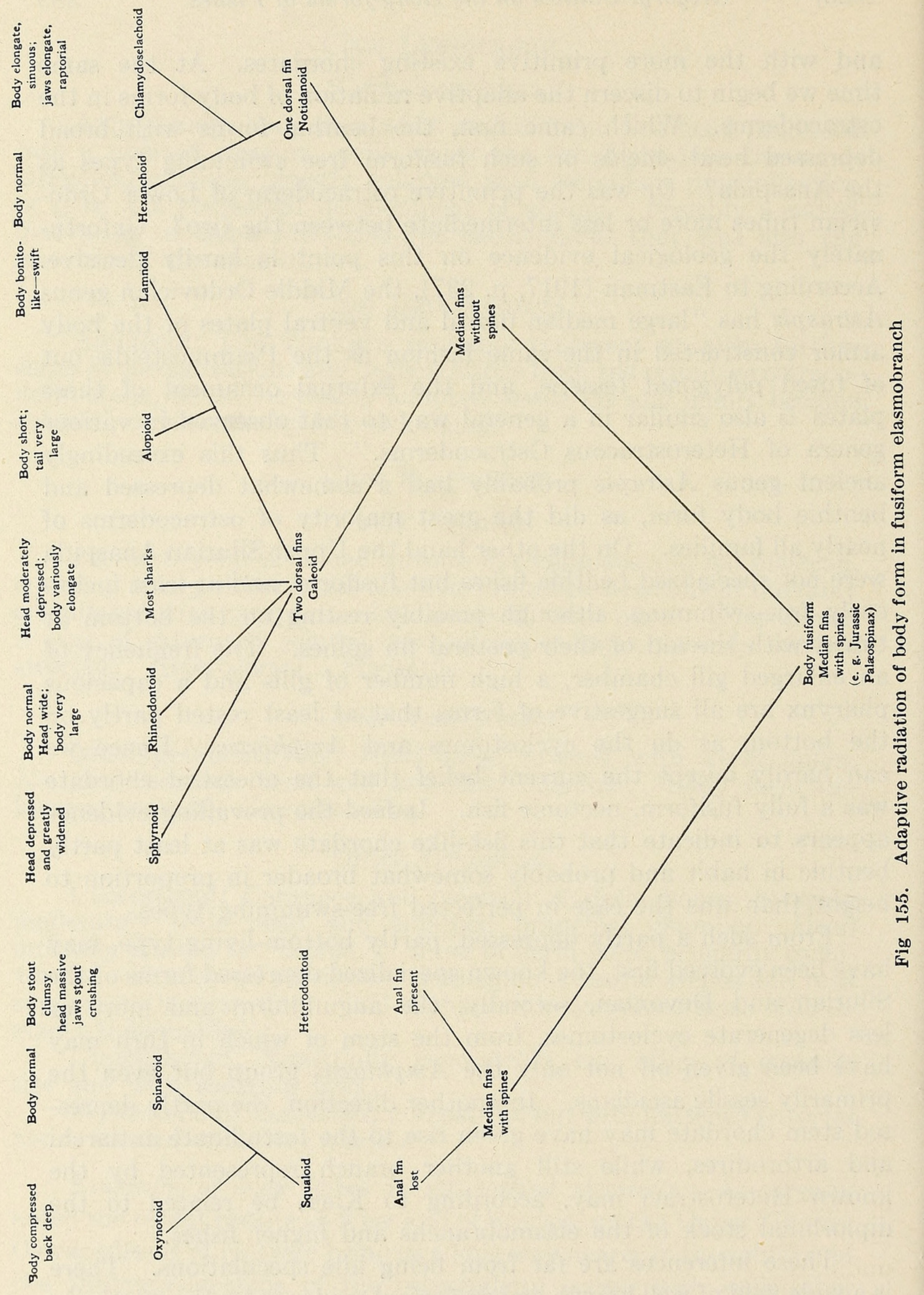


close connection of the larval lamprey with Amphioxus, and in another direction, equally good evidence for connecting the Tunicata with the Amphioxus branch. Balanoglossus, on the other hand, is at best remotely related to the true chordates and it may represent another highly retrogressive series from the very base of the chordate stem (Delage and Hérouard).

There is also much negative evidence for connecting the existing cyclostomes with the monorhinal ostracoderms, for there is no other known group from which they could so easily be derived, according to numerous well founded analogies of the derivation of naked anguilliform types from armored and short-bodied ancestors. In another direction, Traquair and Kiær have recognized the elasmobranch affinities of Thelodus and Lanarkia, which are covered with shagreen denticles or placoid scales, while the ganoid-like scalation of Birkenia and the true bone cells in Osteostraci indicate that even the Osteichthyan fishes may be connected with the ostracoderm stock.

\section{ELASMOBRANCHS}

Body forms and fins of fossil sharks. - The oldest sharks in which the body-form is known are the little acanthodians of the family Diplacanthidæ. These differed widely from modern sharks in having the body short and relatively deep. Nevertheless the lateral contour was essentially shark-like in the following particulars:

1. The body contour fitted well to a simple quadrilateral frame with nearly equal dorsal and ventral triangles, and with the usual convexity above the entering angle.

2. The tail was heterocercal, the opisthion being located at its posterior border as in many modern sharks.

3. There were two stout dorsal fins located above the posterodorsal slope, the first being above the apex as is Heterodontus; the second dorsal was above the anal.

4. The pectorals, ventrals and anals had their usual positions.

On the other hand a profound difference from modern sharks was the relative immobility of the pectorals and ventrals, which were supported by great rigid spines. All the median fins had little or no free movement and served first in preventing lateral displacement and overturning, and second as fulcra for the turning and undulations of the body and tail. The pectoral fins, having a dermal shoulder girdle to support them may have been capable of somewhat freer movements. 
From this relatively primitive type of acanthodian, A. S. Woodward (1915) has recognized two divergent lines of evolution, one tending toward more massive spines and retaining a short to depressed body (Diplacanthus to Gyracanthus), the other tending to reduce the spines to a needle-like slenderness and to elongate the body greatly (Cheiracanthus to Acanthodes gracilis). In this second line of descent the bounding quadrilateral becomes very elongate, the low vertical diameter of the back, together with the relative thickness of the tail, making the slope of the back very slight and bringing the opisthion far behind the uranion. The needle-like fin spines offered little resistance to lateral displacement and no doubt the mode of progression was almost anguilliform.

The Devonian shark Cladoselache as described by Dean (1909) shows the following peculiar combination of characters:

1. The body is dolichosomatic, probably lower and wider in cross section than that of typical sharks. The head was certainly low, and fairly broad, with large terminal mouth. The pectoral fins were widely extended laterally and the body fairly low across the pectoral region, with a relatively low first dorsal fin. Thus the head as a whole was probably not unlike that of the living Chlamydoselache as were also the jaws and branchial arches.

2. The median and paired fins all had widely extended bases not exserted posteriorly from the body, and supported by radially arranged cartilaginous radials which extended nearly or quite to the tip of the fin. Thus the median and the paired fins were essentially similar in construction and afford strong evidence for the view that both were derived from fin folds (Dean, R. C. Osburn). All the fins served rather as keels and balancers than as paddles.

3. The tail fin was very large externally, homocercal in type and supported by horizontal transverse paired fins on either side of the caudal peduncle, the nearest analogue being the wide lateral keels of the mackerel sharks.

From these data we may conclude that the enlarged tail was the principal propellor, its thrusts being regulated by warping movements of the extended planes of the pectorals, dorsals and ventrals. The wide pectorals served as a relatively stable sling for the sinuous movements of the head and body.

Not much that is definite can be said about the quadrilateral of the body in side view because nearly all the specimens of Clado- 
selache are flattened dorso-ventrally; but its vertical diameter was probably relatively less than in typical modern sharks.

The pleuracanth sharks of the Carboniferous and Permian seem to have been a highly specialized swamp-living offshoot of the cladoselachian stem. The body is much elongated and tapering, especially the dorsal and caudal parts with their fins; the bases of the pectoral fins have become concentrated and the pectoral fins, and to a less extent the pelvic fins, have become paddle-like. Locomotion was doubtless of complex type, in part by means of lateral undulations of the body and tapering tail, in part by independent undulation of the greatly elongate dorsal and caudal fins (after the fashion of Gymnotus), in part by paddle-like movements of the pectorals. The skeleton of the peculiar anal fins somewhat resembles that of the small dorsal fin of the ray Psammobatis (figured by Tate Regan, 1906, p. 755) in so far as it has a main jointed axis with obliquely branching radials. In both cases these structures have very probably been derived by the crowding together and partial concrescence of the basals and radial cartilages of more normal antero-posteriorly extended fins.

The presence of a large occipital spine, and of massive jaws, as parts of a freely movable head, probably influenced the evolution of strong paddle-like paired fins to assist in the movements of those parts. The enlarged pectoral girdle acts as a sling for the head and thorax and also as a base for the pectoral paddles. As restored by Fritsch and others, the body form of Pleuracanthus and its allies in lateral view conforms to an elongate quadrilateral type.

Body-form and fins of recent sharks. - The most fundamental characteristics of the body-forms and fins of modern sharks are as follows:

1. As sharks progress by lateral undulations of the entire body, the head being relatively low and offering but little lateral resistance, would sway widely from side to side if it were not checked by the large first dorsal and the pectorals, which form the anterior pivot.

2. The body is dolichosomatic and except for the tail itself, it usually follows closely the inscribed quadrilateral figure. The widest part of the body is often at the posterior end of the lower jaw, where the section is transversely ovoid; sometimes the greatest width is across the base of the pectoral fins where the section is more or less triangular, broadly flattened below and rounded above. 
3. The tail which is always heterocercal, has a tendency to depress the head. This is corrected, as noted by Breder, by the pectoral fins and by the flattened lower surface. In certain sharks the caudal axis is sharply raised and the lower lobe of the tail grows downward so that the tail-spread much exceeds the vertical diameter of the quadrilateral and the caudal angle is markedly increased. Thus the tail as a whole approaches the fast swimming scombroid homocercal type.

4. The upward component of the tail-thrust, tending to raise the column posteriorly and depress the head, is doubtless partly compensated by the relative flatness of the throat and underside of the rostrum, which would tend to push the head upward. Possibly the pectoral fins are in a position to regulate and compensate the opposing thrusts of the head and tail. (Breder). Indeed the alternation and spacing of the fins on the dorsal and ventral sides of the long body have the appearance of balancing it, like weights on a steel yard.

5. The median, and even the paired, fins are much less mobile than those of teleosts and hence retain more of their primitive function of keels and rudders rather than paddles. Hence, as noted by Breder, sharks do not stop suddenly but swerve to one side of an obstacle.

6. The posterior pivot for the posterior part of the body, including the tail, is formed by the ventrals and second dorsal.

7. All the median and paired fins tend to have a convex anterior and a concave posterior border. The convex anterior border offers less resistance to the water than a straight border would, since it is curved backward and its thickness diminishes posteriorly. A convex posterior border would offer more resistance to the water displaced by the fin; a straight anterior border would cause suction at the end; and would push the water ahead of it instead of allowing the water to flow backward; a convex anterior and concave posterior border avoids both these conditions.

Among the most variable factors in the body-form of the sharks are the size and position of the dorsal fins. The anterior dorsal is typically a high keel that collaborates with the pectorals in keeping the fish right side up; it is primitively of large size, located at the summit of the back above the vertical of the quadrilateral, but with its posterior part on the postero-dorsal slope. The first dorsal fin is extremely large in the giant Cetorhinus maximus where presumably it aids stability; and very small in Centroscymnus coelolepis, whose ability to roll over and to move the head laterally may possibly be increased by this circumstance. This first dorsal is often large in 
forms with a prominent development of the dorsal lobe of the caudal fin, as in Gyropleurodus, Ginglymostoma, Sphyrna, Isurus, Lamna, Cetorhinus. Occasionally, as in Scylliorhinus, Catulus, Pristis, the first dorsal is shifted backward to lie on the postero-dorsal slope above the ventrals. Such backward displacement of the dorsal increases the relative stability of the posterior slope and tail and increases the postero-lateral thrust of the caudal end of the body.

The second dorsal always lies on the postero-dorsal slope and is often paired with the anal. Pressure on either eyeball of a dying shark will at times cause the posterior borders of the second dorsal and anal fins to be moved simultaneously away from the mid line, a fact which shows that these fins are connected with each other in the brain. At other times pressure on the eye ball will cause movements of the first dorsal. In the Isuridæ which have a very large, almost homocercal caudal, the second dorsal and the anal are both much reduced, since the stabilizing function is assumed by the lateral keels.

The pectorals in most sharks lie on or below the antero-ventral slope and thus quite low down on the body, where, as noted by Breder, they compensate the tendency of the caudal fin to push the head downward. The general plane of the pectorals is slightly upturned in front.

The ventrals of sharks lie far behind the vertical diameter of the quadrilateral and near the root of the fleshy caudal part of the body. They also lie in a nearly horizontal plane, and on the posteroventral boundary line. In addition to their functions of stabilizing and steering, they undoubtedly afford a base for the lateral undulation of the tail.

When the anal fin is lost, as in Squalidx, the ventrals move back below the posterior dorsal, with which they doubtless coöperate. The anal is usually paired with the posterior dorsal. Probably they both steady the lateral movements of the tail as noted above. The anals are reduced in the Isuridæ and absent in the Squalidæ.

The heterocercal caudal fin of sharks, has been studied by many authors (e. g. Dollo, Schmalhausen, Abel). It is of extremely primitive type, the fleshy part being merely a posterior prolongation of the body and sharing in the latter's undulations.

The flattened underside of the body of sharks also fits well to the quadrilateral frame. The entering angle is always greater 
than the posterior, and the widest diameter is well forward, normally either across the pectoral fin bases or across the back part of the lower jaw.

The Body-form in Depressed Elasmobranchs.-The quadrilateral outline is equally evident in elasmobranchs of depressed body-form, such as Pristis and the skates, in which the principal wedge is horizontal instead of vertical. In the side view, owing to the enormous lateral expansion of the pectoral fins, the entering and posterior angles become small. In Pristis (Fig. 131) on account of the great elongation of the snout, and in order to give the head a wide swing from side to side, the pectorals, dorsal and ventrals are moved backward and with them the vertical diameter, which is small in proportion to the horizontal. The edge of the entering wedge is transverse so that the principal pressures due to forward locomotion are above and below.

In Fig. 120D, around the top view of Rhinobatus is circumscribed a figure which approaches the posteriorly elongate rhomb of normal sharks. The ventral view presents a similar form, intermediate between sharks and rays.

In the skate-like batoids (Fig. 132) the rhomboid figure that may be drawn so as to touch the end of the tail and the tips of the pectorals becomes empty posteriorly as the pectorals become dominant over the ventral and caudal fins.

In the electric rays (Torpedo or Narcine) the disc is rounded in front and part of the pectoral muscles are transformed into electric organs. In the Eagle rays (Aëtobatidæ, Mobulidæ) and their allies, in which the pectorals have become enlarged into great wings, the transverse diameter of the quadrilateral far exceeds its anteroposterior diameter, and the caudal end of the body is reduced to a long tapering trailer, which possibly assists slightly in turning.

The Body-form in Chimæroids.-Passing to the Holocephali (Figs. 137A, 127A) we observe that an excellent account of the movements of Chimæra collei has been given by Dean (1906, p. 16). In this highly specialized elasmobranch the head is large to support the powerful crunching jaws. Forward progression is largely by means of the wing-like pectorals, no doubt aided by the lateral undulation of the long tapering body. Consequently the entering angle is large $\left(49^{\circ}\right)$, the posterior angle small $\left(11^{\circ}\right)$ and the vertical diameter short, compared with the horizontal. The 
general body-form thus converges toward that of the macrurids. The body turns upon, and is kept upright by, the high first dorsal and large pectorals. The greatly elongate second dorsal can be undulated antero-posteriorly as well as moved with the caudal prolongation of the body. Contrary to what obtains in many fishes with an elongate dorsal, the anal fin is not paired with the latter, but is conjoined with the lower lobe of the caudal, which is diphycercal-filiform. When resting quietly in a tank, the fish often drops the tail and rests upon the tips of its downwardly directed paired fins (Dean).

In Harriotta (Fig. 127A), a deep sea form which has retained the primitive rostrum of the Mesozoic chimæroids, the ventral vertical deepens with the deepening of the abdomen, and the dorsal vertical and antero-dorsal angles are correspondingly diminished.

Callorhynchus in general is far more primitive in body form than Chimæra, and is more or less intermediate between the latter and a normal shark type. The Mesozoic chimæroids were not fundamentally dissimilar from their modern relatives.

Summary of Body-forms of Elasmobranchs.-The principal body forms of ancient and modern elasmobranchs (including the chimæroids) may accordingly be listed as follows:

Acanthodoid: Mesosomatic to dolichosomatic; essentially galeoid (see below), but with relatively immobile fins supported by prominent spines.

Cladoselachoid: Dolichosomatic, body probably wider than in most modern sharks. Essentially galeoid (see below), but with tail pseudo-homocercal and supported by lateral keels. All fins keel-like and mobile, permanently erected, but with serially disposed supporting rods of cartilages which were doubtless used in warping the surface of the fins. Dorsal fins two, the first with (Ctenacanthus) or without (Cladoselache) a supporting spine.

Pleuracanthoid: Dolichosomatic, essentially galeoid (see below), but with greatly elongated dorsal fin, long diphycercal tail, enlarged biserial paddle-like pectorals and extended uniserial pelvic fins. A large erectile nuchal spine.

Heterodontoid: Mesosomatic, tail heterocercal. Head thick-set to support powerful crushing jaws; two dorsals with strong spines firmly supported on the back bone by cartilage bases.

Galeoid: body fusiform, dolichosomatic; head more or less depressed; tail heterocercal; paired fin well developed. Two dorsals without spines. Sinuous movement pivoted on prominent dorsal, pectoral and ventral fins. Free swimming, mostly pelagic. 
Notidanoid: Dolichosomatic, essentially galeoid, but with only one dorsal. somatic.

Chlamydoselachoid: essentially notidanoid but hyperdolicho-

Lamnoid: essentially galeoid but body bonito-like; large tail with well raised caudal axis supported by lateral fin folds. Posterior dorsal and anal fins much reduced. Swift swimming, pelagic.

Alopioid: essentially lamnoid but with heterocercal tail greatly lengthened: body short and thick; head relatively small and conical. The long trailing and lashing tail is used in rounding up the schools of small fish upon which the "thrasher" feeds.

Sphyrnoid: essentially galeoid but with head much widened, depressed and shortened antero-posteriorly. Movements galeoid, but with ability to make sudden dives and quick turns by means of the horizontal keel formed by the flattened head.

Squaloid: essentially galeoid, but without anal fin, and with a strong spine on each of the two dorsal fins. ened.

Oxynotoid: essentially squaloid but with the back greatly deep-

Rhinobatoid: intermediate between the galeoid and raioid forms: $i$. e., body depressed anteriorly, pectorals expanded laterally but much less so than in raioids, post-pectorals part strongly developed, tail heterocercal. Gill slits inferior; mostly bottom-living.

Pristioid: essentially rhinobatoid but with the rostrum greatly produced and armed on either side with a row of socketed teeth.

Rhinoid (squatinoid): essentially squaloid but eurysomatic, and eurybrachial with laterally extended pectoral fins. Tail heterocercal, well developed.

Raioid: body depressed (eurysomatic), more or less rhombic in top view, due to the great lateral expansion of the pectorals, which grow forward to the end of the snout and backward to overlap the ventrals; post-pectoral parts reduced. Locomotion chiefly by means of enlarged pectorals. Typically bottom-living.

Torpedinoid (Narcobatoid): body depressed, more or less circular in top view, the widely expanded pectorals partly modified into an electric organ. Post-pectoral parts not reduced.

Dasybatoid: body depressed, eurysomatic, the disc subquadrangular to subcircular, tail long whip-like with a strong serrated spine.

Mobuloid: body depressed extremely eurysomatic, the disc becoming nearly twice as wide as long. Tail reduced to a long thin trailer.

Myriacanthoid: somewhat galeoid in type, but with rostrum greatly produced and with large spine on dorsal fin. Pectorals paddle-like, with lobate fleshy base.

Callorhynchoid: essentially myriacanthoid but with shortened and flexible rostrum and reduced dorsal spine. Tail heterocercal. 
Chimæroid: essentially callorhynchoid, but with shortened conical rostrum, head large, steadied by prominent first dorsal fin, which is supported by a strong spine. Paddle-like pectorals and pelvics dominant over relatively feeble tail; second dorsal, with greatly elongate base coöperating with elongate filiform tail. rostrum.

Rhinochimæroid: essentially chimæroid but with elongate

Harriotoid: rostrum greatly produced, abdomen very large. Otherwise much as in Rhinochimæra. A deep water form.

\section{Chondrostei, Holostei ANd Teleostei}

\section{Chondrostei}

In the Devonian and Carboniferous Pæoniscidæ, which stand at the very base of the ganoid-teleost series, the body-form conforms to the ordinary quadrilateral types, in which the part behind the vertical is moderately produced and the opisthion is well behind the uranion. The entering and posterior angles vary in the different genera with the height of the body. In the Devonian Cheirolepis, a prototypal forerunner of the whole osteichthyan series, the body-form is moderately dolichosomatic with all the fins of small to moderate size; the caudal fin was completely heterocercal and body movements were doubtless shark-like. The jaws are large and the fish was doubtless a comparatively swift predatory type.

In Palæoniscus the single dorsal lies on the dorso-posterior boundary just behind the dorsal vertical. It is thus in a pivotal position both for keeping the body upright and for assisting the pectorals in lateral turning. All the fins except the caudal are relatively small as compared with those of most teleosts, and it is evident that the principal method of progression was by lateral undulation of the body. Moreover the fin rays in all the fins are barely differentiated from the body scales, and very likely the fin muscles were less differentiated from the body muscles than they are in later fishes. In Amblypterus the fins are larger. The head of Palæoniscus is neither depressed, as in sharks, nor compressed, as in many teleosts, but rounded anteriorly, and it could evidently be pushed readily in any direction. The jaws are large and of carnivorous type but with delicate teeth. Palæoniscus seems relatively inefficient in stopping suddenly, since its pectorals and dorsal are small. The large heterocercal tail would seem to have the tendency to push the head downward but this may have been 
corrected by contrary bendings of the body and by the bluntness of the snout.

In swimming the head must have swung from side to side through a larger arc than is the case with compressed teleosts with large heads. This is evidenced by its small size, its relatively large distance from the dorsal fin, and the small size of the pectorals, which in higher fishes steady the head.

The scales of the older ganoids did not overlap posteriorly and the body may have been less flexible than it is in smooth-skinned fishes, but on the other hand the vertebral centra were but feebly developed and the vertebral axis may have been quite flexible, the main strengthening being by means of the scales. Amblypterus, Trissolepis, Coccolepis, and Eurynotus had larger fins than did Palæoniscus and to this extent they foreshadow the modern teleosts.

The Platysomnidæ were small-mouthed or nibbling, more or less deep-bodied fishes which were derived directly from typical palæoniscids, the body finally becoming very deep and compressed, the circumscribed quadrilateral becoming almost a square. The deepening of the body increases the strength and sturdiness of the fish, giving power to pluck small organisms from the rocks. Hence the entering and posterior angles increase with the depth, the dorsal and anal fins become greatly elongated on the posterior boundaries of the quadrilateral, opposing each other as they do in many later deep-bodied fishes; and no doubt they served primarily as keels and rudders. By undulations running up and down along their borders the dorsal and anal fins must have started successive series of pressures, the general directions of which would have been transverse to the mid-plane. If both dorsal and anal undulations were towards the rear at the same moment, the resultant pressure would be in an anterior direction, as in deep-bodied carangids. On the other hand, if the undulations along the dorsal and anal fins were passing in opposite directions, the resultant torques would tend to rotate the body in a vertical plane. The short truncate pectorals are evidently sufficient both for steering upward and downward and for turning, the ventrals being absent. The tail, also as in carangids, is large and lunate doubtless for the same reasons (cf. Breder, 1926) as in modern fishes. Some of the less specialized platysomids parallel the deep-bodied Sparidæ, having a high, arched back, a deep head and shallow abdomen. Here the pectorals are enlarged, possibly to prevent overturning. 
Dorypterus is another deep-bodied Chondrostean, the sole known genus of a distinct family which, to some extent parallels certain Pycnodontidæ (cf. Abel, 1919, p. 194; Gill, 1925). It is hypsisomatic and hypsigastric, with a very high projection of the dorsal fin, elongate, functionally paired dorsal and anal and a deeply forked tail. Thus, as noted by ${ }^{\circ}$ Gill, this genus was of the deep-bodied coralfish type. The difference in height between the anterior and the posterior verticals being great in proportion to the horizontal distance between them, the postero-dorsal slope is steep and the opisthion is close behind the pygidion and well in front of the uranion as in some other deep-bodied fishes. Beneath the anterior part of the dorsal fin there are one or two endoskeletal fin-supports for each epineural arch; beneath the elevated process of the fin there were two such supports for each epineural block, while beneath the posterior half of the fin there were three for each block. In the anal fin there was no exact correspondence between the endoskeletal fin supports and the hypural blocks. There was also no correspondence between the endoskeletal fin supports and the far more numerous dermal rays of the fins. Hence we may perhaps infer that in this fish as in the earlier Palæoniscidæ the erector and depressor muscles of the fins were incompletely differentiated from the great myomeres of the flanks which bent the back bone.

The Catopteridæ were Triassic derivatives of the Palæoniscidæ which progressed toward the higher grade of evolution by changing the tail from a heterocercal to a hemi-heterocercal type, but they retained a primitive palæoniscoid type of skull, while their more progressive relatives, Acentrophorus went on to the next higher grade represented by the Semionotidæ. The body is elongate fusiform as in many later forms, the opisthion lying far behind the uranion. The dorsal and anal are large, opposed to each other and placed well behind the vertical, this condition permitting a wide lateral movement of the head. The caudal fin is large and almost homocercal, its vertical diameter equaling that of the body. The upward turning of the vertebral axis in the tail indicates that the subvertebral proximal tail muscle was beginning to point obliquely upward and backward as in modern ganoids and that the power of the tail to start undulatory movements of its own was increasing. With this upturning the principal thrust of the tail fin is no longer upward but more antero-posterior in direction. 
The Jurassic Chondrosteus is structurally intermediate between Palæoniscus and the modern sturgeons (Woodward, Watson). It has progressed beyond the former in the elongation of the body, increase in size of all the fins, reduction of the scales, withdrawal of the mouth beneath the well developed snout. Its quadrilateral is not dissimilar to that of Acipenser brevirostris, except that the vertical is further forward. The single dorsal lies above the ventrals and is not opposed to the anal as it is in Acipenser. In the latter the body form is elongate-rhombic, with a low vertical diameter. The opisthion is near the pygidion. The posterior position of the ventrals, dorsal and anal, imply a wide lateral swing of the head which is somewhat flattened on the under side. The slight upward slope of the under side of the head, producing an upward counter thrust from the water, is probably sufficient to compensate for the downward component of the thrust from the heterocercal tail. The function of the rows of dorsal and lateral scutes, which have replaced the body scales, is not clear, unless they aid as keels in preventing the body from rolling over. The sturgeon from the position and form of its mouth is evidently a bottom-feeding form, which moves slowly and needs to maintain its position in spite of currents. This ray-like tendency is further expressed in Scaphirhynchus with its low depressed snout.

The Spoonbill (Polyodon) and its relative Psephurus have evidently been derived from a form like the Jurassic Chondrosteus by the great development and flattening of the snout and elongation of the mouth, the fins remaining much as they were, except for the further enlargement of the dorsal and anal. These now are shifted back near the tail as in other long snouted forms, and facilitate the side swinging of the enormous rostrum. The under side view of Polyodon shows how the rostrum and body-form alike conform to stream-line requirements. As in the batoids the under-side view as a whole represents two quadrilaterals conjoined, an anterior one including the lateral expansion of the rostrum, and a posterior one including the axis of the rostrum and the body itself. The pectorals are weak, but the posterior fulcra for lateral bending (dorsal and anal) are strongly developed. 


\section{HoLOSTEI}

Acentrophorus, the Permian forerunner of the Holostei is transitional in the form of its tail between the heterocercal palæonescoids and the abbreviate-heterocercal Semionotidæ. The three species recently restored by Gill (1923) vary from mesosomatic to subhypsisomatic in proportions. The single dorsal lies on the posterosuperior slope, behind the dorsal vertical and is functionally paired with the well developed anal. The pectoral and ventral fins are not large but the tail is large and lunate to truncate. Each fin ray has a single endoskeletal supporting rod, so that the muscles for erecting the fins must have approached the modern conditions. The mouth is small, the eye fairly large. These must have been quick turning fishes.

Dapedius carries further the tendency to deepen the body, which culminates in the Pycnodontidx. Here it is almost rhombic in form. The dorsal and anal are increased in length and oppose each other on the posterior boundaries of the quadrilateral, no doubt acting together to produce slow forward or backward movements. More rapid movements were doubtless executed by lateral undulations of the body and by thrusts of the broad tail, which is externally homocercal. The latter, however, was not fastened so efficiently to the back bone as it is in later fishes with expanded hypural bones.

The back-bone has an anterior convexity above the swimbladder and body cavity, and a posterior concavity that runs up into the heterocercal tail. Possibly this sigmoid flexure, which is often present in deep-bodied fishes, may have strengthened the backbone against the opposing thrusts of the body and of the medium; it may also have served as a spring to oppose undue crumpling of the body by the myomeres. But very possibly the principal reason why the backbone arches upward anteriorly is to bring it above the swelling swimbladder, while the reason why it slopes downward posteriorly is to bring the tail thrust directly behind the centre of gravity, which is located in the swim bladder, and below the anterior part of the column. Finally the terminal upturning of the column may be a response to the upward component of the thrust of the internally heterocercal tail.

The more specialized pycnodonts parallel later deep-bodied 
fish such as Platax and the Ephippidæ. The dorsal and anal fins are shifted posteriorly so that their bases are steeply inclined to the horizontal and their thrusts are at about $45^{\circ}$ to it. The caudal is broad and externally homocercal. As in other deep-bodied fishes the ventrals are reduced, their normal functions, including that of assisting in keeping the body upright, being taken over by the dorsal and anal fins. No doubt this powerful apparatus gave a firm stance in plucking up the shelled molluscs upon which the pycnodonts probably fed.

Lepidotus of the Semionotidæ was a medium to stout-bodied more or less Hæmulid-like fish with relatively smaller and less efficient fins than those of modern heavy bodied teleosts. The bounding quadrilateral comes close to the body except on the antero-dorsal convexity. The dorsal fin is displaced to the posterodorsal slope and opposes the anal. The tail is hemi-heterocercal.

The modern Lepidosteus may be regarded as a long-bodied, long-snouted derivative of a Lepidotus-like holostean. ${ }^{1}$ As in many other predatory forms with an elongate snout the horizontal is long as compared with the vertical and both entering and posterior angles are small. The anterior dorsal vertical being relatively far forward from the posterior vertical and the difference in height between them not great, the postero-dorsal slope is gentle and the opisthion is well behind the uranion. The posterior vertical axis of turning, which runs through the opposed dorsal and anal, is moved very far back, which gives a wide lateral sweep to the elongate snout together with quick turning ability. The well developed ventral fins lie nearly in the middle of the body and no doubt coöperate with the pectorals in vertical changes of direction. The broad diphycercal tail gives a powerful thrust against the water.

Rather similar proportions obtained in the Mesozoic Aspidorhynchidæ, which were amioid analogues of Lepidosteus. The fins however are smaller.

Caturus furcatus, a Jurassic amioid, as restored by Smith Woodward, was a swift, evidently predatory fish with carnivorous jaws and large forked tail, the spread of which considerably exceeds the vertical diameter of the body. The general contour conforms perfectly to the normal quadrilateral type. The other fins are smaller than in modern fishes of similar body form. The length of

${ }^{1} \mathrm{cf}$. Goodrich '09, pp. 342, 344. 
the body, to the fork of the tail, is a little more than four times its depth. As shown by inspection of the endoskeletal supports of the fins, the fin muscles of the dorsal, anal and ventral fins were completely differentiated from the vertebral muscles of the flanks.

Hypsocormus insignis is a more specialized predatory amioid than Caturus, with a deeper body, in which the length is only a little more than three times the depth. The tail is very large and deeply forked and the fish was evidently a swift swimming form. In response to the deepening of the body the dorsal and anal fins have become larger and more extended posteriorly, as compared with those of Caturus, and they have also tended to supersede the ventrals which are decidedly reduced.

The modern Amia, a modified descendant of the Jurassic Megalurus, has departed widely from the more primitive body-form represented in Caturus. The leading feature is the elongation of the body and especially of the dorsal fin, which can be thrown into antero-posterior undulations producing slow forward or backward progression (Breder). The tail also is strongly built and convex with a deep, thick peduncle. The result of these conditions is that the posterior dorsal vertical is but slightly less than the anterior dorsal vertical, consequently the slope of the dorsal fin base is slight and the opisthion is thrown far to the rear. The pectoral and pelvic fins have remained small (contrast the much larger fins of typical teleosts) and occupy about the same relative positions that they did in Caturus. The anal fin has increased a little, but the partly heterocercal caudal fin has become broadly diphycercal instead of lunate, thereby probably gaining a more powerful thrust in a forward and upward direction, possibly to oppose the forward and downward component of the dorsal, and thus produce forward locomotion.

The principal types of body-form among the Holostei may be listed as follows:

Palæoniscoid: the most primitive ganoid type, body mesosomatic, fusiform, movements essentially galeoid; pivoted on single dorsal, small pectoral and ventral, moderate anal; tail large, heterocercal, bifurcate; median fins incipiently erectile and but little extensible; hence turning and stopping movements probably less rapid than in typical teleosts. Stream-living.

Platysomoid: a deep-bodied (hypsisomatic) derivative of the palæoniscoid type; elongate dorsal and anal, on posterior slopes, 
doubtless important in turning movements, but not as strongly constructed as in deep-bodied teleosts.

Dorypteroid: a deep-bodied derivative of the palæoniscoid type, with excessively high dorsal fin.

Chondrosteoid: intermediate between palæoniscoid and acipenseroid types; as compared with the former the body more elongated, all fins larger. type.

Polyodontoid: a long-billed modification of the chondrosteoid

Acipenseroid: an armored derivative of the chondrosteoid type but with the snout produced, the dorsal fin shifted backward, above the anal, and the pectorals strengthened by a stout bony anterior ray; tail heterocercal; movements essentially galeoid.

Semionotoid: body fusiform to moderately deep, compressed, more or less sparid-like; single dorsal on postero-superior slope opposing anal; tail strongly developed, externally homocercal, lunate. Stream-living.

Dapedioid: body becoming orbicular; a deep bodied derivative of the primitive semionotoid type. Tail externally homocercal, truncate. Inshore fishes with small mouths.

Tetragonolepoid: an extremely bathygastric derivative of the primitive semionotoid type.

Pycnodontoid: a hypsisomatic derivative of the semionotoid type differing from the dapedioid from in the additional bracing of the vertebral column.

Lepidosteoid: dolichosomatic derivative of the semionotoid type, with elongate rostrum, posteriorly displaced turning fins (dorsals and anals) and powerful convex tail. Predatory, stream-living. Paralleling the esocoid type.

Macrosemioid: derived from primitive semionotoid form by elongation of the body and elongation and enlargement of the dorsal fin.

Caturoid: possibly derived from primitive semionotoid type by moderate elongation of body and of jaws; dorsal fin moderate, near summit of back; caudal fin large, ventral and anal small.

Pachycormoid: swift-swimming derivative of the caturoid type, with moderately deep back, very large furcate tail, delicate peduncle, moderately elongate anal, moderate dorsal, reduced ventral and moderate pectoral.

Euthynotoid: elongate almost Coryphæna-like derivative of the pachycormoid type.

Protosphyrænoid: a derivative of the pachycormoid type with an elongate pointed rostrum and enlarged pectoral fins with serrate anterior border.

Oligopleuroid: body form similar to caturoid type but with centra better developed. 
Amioid: a moderately elongate derivative of the caturoid type; Megalurus with more normal dorsal, Amia with greatly elongate dorsal, capable of strong longitudinal undulations; tail spatulate; pectoral, pelvic and anal fins moderate. Stream-living.

Pholidophoroid: more or less herring-like derivatives of a primitive short-bodied (disciform) type (Abel); body moderately elongate, fins small.

Thoracopteroid: a flying-fish derivative of the pholidophoroid type, with greatly enlarged pectorals and strongly developed hypochordal lobe of the caudal fin. (Abel.)

The body-forms of a few representative teleosts are listed on p. 414 .

\section{TELEOSTEI}

The body-forms and fins of teleosts will, it is planned be discussed more in detail in later numbers of this series, but in the present paper I would like to record several incidents that have come under my observation which suggest the complexity of the locomotor apparatus in the higher teleost fishes and the marvellous quickness and precision of their movements. The first incident was observed in the aquarium at Honolulu in 1921 by Mr. H. C. Raven and myself and is thus related in "Natural History," 1921 page 555: "There were a number of 'Akilolo' wrasses (.Julis pulcherrima) in one tank swimming about very actively. As we approached, one of them suddenly emerged from the sandy bottom where he had been lying buried, and immediately another made a dash at him but missed him. Then began a chase of dazzling quickness and intricacy. The two fishes flashed back and forth, up and down, dodging and turning like a couple of brilliantly colored flies, and it seemed a marvel how they steered clear both of the rocks in the center and of the sides and bottom of the tank. After some seconds the pursuer succeeded in nipping and breaking off parts of the dorsal fin of his victim, evidently damaging the latter's steering gear and causing him to tilt and wabble in his course. The pursued then dived into the sand, covering himself completely. The aggressor hung around awhile, nosing about and evidently waiting for another chance to attack, but after returning to the spot several times, finally gave it up.

"From the viewpoint of comparative anatomy this incident is instructive, because it affords an example of very complex actions, having the appearance of being guided by intelligence, but con- 
trolled by a brain which entirely lacks the highly developed 'cerebral hemispheres' of mammals and birds."

The second series of observations was made by me upon various small fishes living in the tide pools in the Galapagos and Cocos Islands. In trying to net these fishes, including the young of pomacentrids, gobies and wrasses, I often noticed the, at first sight, reckless way in which they hurled themselves about, but at the same time avoided the net and darted through the smallest crevices without striking themselves against the rocks. When the waves dashed into the tide-pools they were equally able to take care of themselves and it was evident that their speeds considerably exceeded those of the waves and currents by which they were buffeted. Whenever one of our party went below the surface in the diving helmet the fat-bodied pomacentrids would crowd around to look at the big stranger. But such was their skill and quickness in dodging that they, and indeed most other fishes, offered difficult targets for our three-pronged spears. Thus both short-bodied fishes, like pomacentrids and chætodonts, and long bodied forms, including wrasses, scarids and morays, were usually successful in evading capture and in avoiding injury from the waves and currents. On the other hand we never saw very small sharks in rocky tide pools and this fact seemed in keeping with the unquestionable superiority of the teleosts not only in the greater size and extensibility of their fins but especially in the far more advanced development and complexity of the optic centers of their brain, which form the dominant organs in coördinating visual impressions with motor responses.

The third series of observations was made by $\mathrm{Mr}$. Dwight Franklin and myself on living specimens of the Sargasso fish (Pterophryne historio) in aquaria on board the "Arcturus." Pterophryne is a short and fairly deep, thick-set, carnivorous little fish, with a very small upturned mouth and great handlike pectoral fins with movable elbows; it has a prominent backwardly extended dorsal fin and downwardly projecting ventral fins that end below in large white "feet." Its golden-brown ground-color with irregular patches of dark brown, flecked with little white circular spots, form a perfect camouflage as the fish lurks on the gold and brown weeds.

When swimming slowly the principal thrusts were caused by the 
rhythmic jets of water from the small rounded gill openings, ${ }^{1}$ modified by the gentle undulations of the pectoral fin membranes.

When crawling along the branches of the weed the Pterophryne sometimes moved as if it were stalking the alert little fishes and crustaceans upon which it feeds. One long pectoral flipper would be slowly swung forward while the opposite one was moving backward, the body being supported below by the large white feet, which turned outward and shuffled away in the well known manner of the cinema comedian.

When resting in the weed the fish maintained his position with all four paired fins and with as many median fins as could reach parts of the weed. One huge pectoral "arm" would be extended almost straight upward, the finger-like tips of the dermal rays clutching a branch of the weed that hung down above the fish; the opposite pectoral was thrust downward and reflected at the "wrist," the "palm" turned outward and forward and the palmar side of the "fingers" touching weed. One long "foot," following another branch of weed, was cocked forward and upward; the other, reaching still another branch, was directed backward and downward. The posteriorly elongate part of the dorsal was folded over and served as another prop, and at other times the caudal and anal fins also coöperated in keeping the fish securely placed in spite of the movements of wind or wave.

But it would be a mistake to infer that Pterophryne was always a sluggish, slow moving fish. When one of these fishes was placed in a large pan and attempts were made to catch it by hand it made great flying leaps, such as it may have made in sudden dashes after its prey or in overtaking the weed after brief excursions.

Thus the pediculate teleost Pterophryne seems to be near the acme of functional and structural differentiation of the parts of the locomotor apparatus.

\section{SUMmaRY AND CONCLUSIONS}

\section{Relations of Body-form to Gravity}

It has been shown in this paper that the body-contours of fishes have certain normally constant relations to quadrilateral

1 These are not homologous with the regular opercular openings of ordinary flshes, but represent a secondary opening at the end of a dermal groove, or tube, that conducts the exhaled water to an exit behind the pectoral fin. 
figures drawn around them. The causes of this fact are doubtless extremely complex, but a few of the more fundamental ones are discernible:

(a). Nearly all organisms are differentiated with reference to the direction of gravitation, into a dorsal and a ventral side. Thus in fishes the apex, the gasterion and the horizontal plane (as defined above) are anatomical expressions of this primary differentiation.

(b). It is not improbable that radiate symmetry is older than bilateral symmetry and is the result of equal growth in all directions from a centre in the horizontal plane. Anteroposterior differentiation into head and tail ends, whether initiated through the assumption of a bottom-living and creeping habit or in some other way, is normally associated with movements in planes, the average direction of which would be tangent to the earth's surface and at right angles to the dorso ventral axis of gravitation. The anatomical points here named prosthion and pygidion dexiterion, aristerion, ( $p$. 334,340 ) which are thus oriented to cosmic forces, reach their definitive positions through differential growth, which, starting from a single cell in the centre, is normally faster in the horizontal than in the vertical axis.

(c). Bilateral symmetry and the existence of all the points and axes of reference herein named are also conditioned by the fact that fishes move in a medium that offers resistance to anteroposterior movement both through pressure due to gravitation and through friction. It is well known that what are called stream-line forms are the most efficient either in deflecting an oncoming stream or in pushing aside the water in forward locomotion. Stream-line requirements in short are responsible for the universal functional and structural differentiation of normal fish body-forms into an entrance and a run, and it is for this reason that the body-forms of fishes fit so nearly into the elongate rhomboid figures described in this paper.

(d). Stream-line contours in fishes are produced by differential growth in the three primary planes, resulting in the observed relations and proportions of the entering and posterior angles, of the dorsal and ventral verticals, of the transverse diameters, etc. Also the observed curvatures of the forehead, back, tail, abdomen, and throat, as well as the form and relations of all the fins, are apparently in harmony with stream-line requirements. Breder (1926) has 
shown very fully how the high pressure areas produced by the undulation of a fish's body and tail are passed backward faster than the fish moves forward and thus produce a backwardly flowing stream. The stream-line tapering of the body toward the posterior end, which makes the posterior angle of the quadrilateral less than the entering angle, is doubtless conditioned by the complex pressure and suction effects both of the water displaced by the head and the backwardly flowing stream of high pressure areas.

Parsons (1888) has shown that in typical fishes the greatest cross section of the body cuts the horizontal line at a distance behind the tip of the snout equal to thirty-six percent of the distance from the snout to the tail base. The exact positions of the apex and gasterion, dexiterion and aristerion, and of the dorsal and ventral verticals of the bounding quadrilaterals, are thus adjusted to produce the conditions noted by Parsons and by Breder.

\section{Relations of Body-form to the Form and Placement of the Fins}

In considering the action of the several fins upon the body and the relations of the fins to the bounding quadrilateral, let us assume for a moment that the body is rigid and that its whole weight is concentrated at its centre of gravity, which is frequently located in the swim-bladder in the anterior part of the thorax (Breder). Then the torques or moments of force of each fin are the components of muscle forces that are at right angles to lines drawn to the centre of gravity, multiplied by the distances along those lines to the centre. In general the fins are grouped in opposing pairs: right and left pectoral, right and left ventral, dorsal and anal, upper and lower lobes of the caudal fin. In forward locomotion not only must the thrusts of normally opposing pairs be balanced (opposite torques around the centre of gravity) but, as shown by Breder (1926), an anterior fin, such as the pectoral, may often combine its thrust with that from one of the posterior fins.

With reference to the median, transverse and horizontal planes of the body, the fins are disposed as follows:

(a) In the median plane: the dorsal, anal and caudal fins, exerting transverse pressures.

(b) In the transverse horizontal plane: the pectorals and pelvics of primitive sharks, and the caudal keels of scombroids, exerting more or less vertical pressures. 
(c) In the vertical lateral planes: the pectorals of many acanthopts, when extended, exerting antero-posterior pressures.

The moments of force of the fins upon the centre of gravity will of course be influenced by the form and angulation of the fins as follows:

(a) Fins are usually directed more or less backward and when deflected to one side or the other they tend rather to draw the body towards them than to push it away from them.

(b) Convex or spatulate fins afford a firm push against the water and require broad powerful muscles to operate them.

(c) Concave fins or those with prolonged tips can be swept over a wider arc with relatively less effort than spatulate fins; they enable one part of a fin to be widely removed from the other and thus to reach to a position of mechanical advantage for certain movements (Nichols, Breder).

(d) In short-based median fins the rudder and paddle function predominates; long based fins can be thrown into longitudinal undulations which also may contribute directly to forward or backward movements.

(e) In general a gentle convexity offers a favorable surface for water to flow away from, a concavity on the other hand may induce a suction effect (Breder), or if reduced to a thin edge may steady or stretch a fin membrane (Breder). A steep slope in a foreand-aft direction is like a wedge with a very obtuse angle which would require a short, sudden and violent effort to push through the water; on the other hand a gentle posteriorly decurved slope, is favorable for slight efforts accumulated in a longer time.

The facts of comparative anatomy and palæontology are all in favor of the view that both median and paired fins were originally merely accessory organs of locomotion, projections of the body wall and skin placed at favorable points to deflect the forces generated by the primary locomotor organs which are the myomeres.

\section{Contrasting mechanisms of dolichosomatic and hypsisomatic forms}

The placement of the points of reference of the quadrilaterals, as well as the dimensions and proportions of the diameters and boundaries are obviously conditioned by the location of the fins; which in turn bears a definite relation to the particular ways in which each kind of fish moves. Thus predatory, pike-like fishes 
have a low entering wedge and a posteriorly placed strong axis of lateral turning (running vertically through the dorsal and anal fins) which permits sudden lateral displacements of the head and fore-part of the body. Hence the apex and the gasterion are placed far back, the downward slope of the base of the dorsal fin is slight, and the vertical diameters are very small. The long body is thrown into eel-like undulations, the amplitude of which increases posteriorly (Breder). In this case forward locomotion results from the longitudinal summation of the contractions of a long series of myomeres. At the other extreme such deep-bodied forms as the pomacentrids and angel-fishes have a high entering wedge, requiring short and very powerful muscles to push it through the water. The powerful posterior axis of lateral turning, by reason of the shortness of the body, is far nearer to the principal fulcrum than is the case in long-bodied fishes. Hence the vertical diameters are relatively great, the pygidion is relatively near to the prosthion and the postero-ventral boundary forming the base of the dorsal fin slopes downward at a sharp angle.

\section{List of principal Body-forms in fishes}

While the number of body forms and precise modes of locomotion in fishes is great even in the groups below the swarming teleosts, a few of the more central or conspicuous types are as follows:

(1) Galeoid: body fusiform, head depressed, body pivoted anteriorly on high stiff dorsals and well developed pectoral fins, posteriorly on ventrals second dorsal and anal fins; tail heterocercal.

(2) Batoid: body and head depressed, pectorals extended transversely and forming the chief organs of locomotion. Tail typically reduced, ultimately to a whip-like trailer.

(3) Palæoniscoid: body fusiform, tail heterocercal, other fins small, but covered with incipient lepidotrichia; body pivoted on single apical dorsal.

(4) Platysomoid: hypsisomatic derivative of the palæonescoid type, with dorsal and anal elongate, opposed, on sloping posterodorsal, and postero-ventral boundaries.

(5) Polyondontoid: a naked derivative of the Palæoniscoid type, with a spoon-bill rostrum.

(6) Acipenseroid: secondarily armored derivative of the palæoniscoid type, with the snout produced, the dorsal fin shifted 
backward and the pectorals strengthened by a stout bony anterior ray.

(7) Semionotoid: primitive holostean ganoid, body compressed, mesosomatic, tail hemi-heterocercal.

(8) Lepidosteoid: a long bodied predatory derivative of the Semionotoid type, with posteriorly displaced axis of lateral turning (dorsal and anal).

(9) Pycnodontoid: a compressed hypsisomatic derivative of the semionotoid type. Small-mouthed nibbling and crushing fishes, somewhat resembling the Ephippidæ among the teleosts.

(10) Caturoid: a fusiform, predatory holostean ganoid type with large forked tail.

(11) Amioid: a long bodied holostean with elongate dorsal fin and spatulate hemi-heterocercal tail.

(12) Pholidophoroid: more or less clupeoid holosteans, the long-bodied ones possibly derived from a disciform type (Abel).

(13) Clupeoid: compressed fusiform mesosomatic isospondyls with abdominal ventrals and no spines on the fins; tail homocercal.

(14) Esocoid: Dolichosomatic predatory haplomi, with posteriorly displaced turning axis (dorsal and anal).

(15) Anguilloid: hyperdolichosomatic, with reduced fins.

(16) Berycoid: primitive acanthopt type: hypsisomatic (disciform), with ventrals thoracic and attached to cleithral arch.

(17) Serranoid: mesosomatic derivative of a primitive berycoid type, with elongate dorsal becoming differentiated into spinous and soft portions; all fins large and highly extensible.

Other teleost types will, it is planned be dealt with in a later paper.

The body-forms of fishes may be referred to the following descriptive series:

(1) depressed (eurysomatic)

(2) fusiform (mesosomatic, dolichosomatic)

(3) anguilliform (hyperdolichosomatic, with reduced fins)

(4) disciform or compressed (hypsisomatic).

Or they may be classed as highly flexible, intermediate, loricate (most ostracoderms, arthrodires, plecostomine loricariids, triglids, Hippocampus) and rigid (e. g. Lactophrys). Such forms are evolved independently in different natural groups. On the other hand each of the body-forms listed in this paper, together with each 
of the very numerous body forms among teleosts, is highly individualistic and represents a unique combination of body and fin-forms with special movements, for which no exact parallel can be found in any other natural group.

\section{The starting point of the fish-like body-form}

In considering Barrell's hypothesis (1916) that the earliest chordates were elongate, eel-like forms that originated in fresh water rather than in the ocean, it should not be forgotten that among recent fishes only a few fresh water forms have succeeded in invading the ocean, while very many pelagic families have sent representatives into the estuaries and streams. But this in itself does not indicate which way the invasion took place in early Palæozoic times when certainly the fishes and presumably the streamgradients and salinities were on the whole different from those of the present day. As to the evidence from palæichthyology it may well be true that most of the known Palæozoic and early Mesozoic fishes are found in epicontinental deposits and that some of the descendants of these fishes (as in the order Isospondyli) have succeeded in invading the ocean. It is also true that many primitive fishes of to-day, e. g., the brook lamprey, all the ganoids, dipnoans, crosopterygii, many isospondyl teleosts, nearly all the Nematognathi, many Haplomi and not a few primitive Acanthopterygii, live or breed in fresh water. But there are also many other primitive types of different grades that have survived in the ocean $(e . g$. sharks, Amphioxus, many isospondyls, Haplomi, Iniomi, and relatively primitive Acanthopts of many families), so that we are not dealing with one invasion and in one direction but with many, in either direction and at different times, each of which must be studied on its own merits in detail, before any far reaching generalization as to the first migration should be made.

As to the frequent assumption that the earliest fishes were elongate and eel-like, the evidence of palæontology as recognized by A. S. Woodward is decidedly adverse, since in all groups in which the palæontological history is known the earliest forms were more or less short-bodied and very unlike an eel. The Silurian Anaspida form an important exception.

The combined evidences of palæontology, morphology, embryology and taxonomy prove only that the primitive chordate was 
orientated to head up stream but it does not indicate whether the current was of fresh or saline water.

The foregoing does not carry us very far toward the solution of the problem of the origin of the vertebrates. Even the primitive ostracoderm of Ordovician times was already, it seems, a typical chordate, with no generally accepted evidences of close relationship to any invertebrate phylum. Unless Patten's way of deriving the chordates from eurypteroid arachnids, with its difficult twistings and transpositions of organs should eventually be proved to be true, we are left with no known intermediate stages to connect the stem ostracoderm (nearest perhaps to the Anaspida) with a bottomcrawling cœlenterate having incipient bilateral symmetry and mesoderm pouches from the archenteron. Nevertheless such a stage, already inferred by Masterman and others from the comparative embryology of the protochordates, seems to afford the most favorable starting point for the chordate locomotor apparatus. In either case it seems probable that the first chordates were by no means eel-like free-swimming forms but somewhat depressed and partly bottom-living forerunners of the anaspid ostracoderms.

ABel, 0.

\section{BIBLIOGRAPHY}

1905. Die Anpassungsformen der Wirbeltiere an das Wasserleben. Schriften d. Ver. zur Verbr. naturw. Kenntn. in Wien, Jahrg. 48.

1912. Grundzüge der Palaeobiologie der Wirbelthiere. Stuttgart. 708 pps., 470 figs.

1919. Die Stämme die Wirbeltiere. Berlin and Leipzig. 914 pps., 669 figs.

1921. Die Methoden der paläobiologischen Forschung. In Abderhalden, Emil, Handbuch der biologischen Arbeitsmethoden, Abt. X, pp. 129-312, figs. 20-120. (3. Die Anpassungen an das Schwimmen. 4. Die physiologische Bedeutung der paarigen Flossen der Fische.)

1922. Ueber den wiederholten Wechsel der Körper-formen im Laufe der Stammesgeschichte der Teleostomen. Overgedrukt, Bijdragen tot de Dierkunde, K. Zoologisch Genootschap, Abt. XXII, pp. 73-87, figs. $1-15$.

BARRELL, JOSEPH.

1916. Influence of Silurian-Devonian Climates on the Rise of Air-Breathing Vertebrates. Bull. Geol. Soc., 27, pp. 387-436, 2 figs.

BERRY, E. W.

1925. The Environment of the Early Vertebrates. American Naturalist, LIX, pp. 354-362. 
Boulenger, G. A.

1904. Fishes (systematic account of Teleostei). (In Cambridge Natural History, Vol. VII.)

BREDER, C. M. JR.

1924. Respiration as a factor in locomotion of fishes. American Naturalist, March-April, Vol. LVIII, pps. 145-155.

1926. The Locomotion of Fishes. Zoologica, Vol. IV, No. 5.

BRIDGE, T. W.

1904. Fishes (exclusive of the systematic account of Teleostei).

(In

DEAN, BASHFORD.

Cambridge Natural History, Vol. VII.)

1895. Fishes, living and fossil; an outline of their forms and probable relationships. Col. Univ. Biol. Ser. III. 300 pps., 344 figs.

1899. The "Devonian Lamprey," Palaeospondylus gunni, Traquair. Mem. N. Y. Acad. Sci., II, Part I, pps. 1-32, Pl. I.

1906. Chimaeroid fishes and their development. Publ. Carnegie Instit., Washington, No. 32, 195 pps. 144 figs.

1909. Studies on Fossil Fishes (Sharks, Chimaeroids and Arthrodires). I. The Cladoselachian Sharks. Mem. Am. Mus. Nat. Hist., IX, Part V, pps. 211-248, Pls. XXVI-XXXII.

1916-1923. A bibliography of fishes. Am. Mus. Nat. Hist., N. Y. Vols. I, II, III.

Delage, Y. AND E. HÉrouard.

1898. Traité de Zoologie concrète. Les Procordés, tome VIII. Paris. Dollo, Louis.

1895. Sur la Phylogénie des Dipneustes. Bull. d. l. Soc. Belge de Geol. de Paleont. et d'Hydrol., Tome IX, pps. 79-128.

1904. Poissons. Resultats du Voyage du S. Y. Belgica en 1897-18981899. Anvers. 240 pps., $12 \mathrm{Pls}$.

1910. La Paléontologie Éthologique. Bull. Soc. Belge de Geol. de Paléont et d'Hydrol. Memoires, Tome XXIII, pps. 377-421, Pls. VII-XI. 1909.

Du BoIs-REYMOND, R.

1914. Physiologie der Bewegung (in Winterstein, 1914, pp. 166-185).

Eastman, Charles R.

1917. Fossil Fishes in the Collection of the United States National

Fritsch, A.

Museum. Proc. U. S. N. M., 52, pps. 235-304, Pls. 1-23.

1883. Fauna der Gaskohle und der Kalksteine der Permformation Böhmens. Erster Bd., ss. 1-183, Taf. i-xlvii. Prague.

Gill, E. LEONARD.

1923. The Permian Fishes of the Genus Acentrophorus. Proc. Zool. Soc. Lond., pps. 19-40, figs. 1-16.

1923a. An Undescribed Fish from the Coal Measures of Lancashire. Ann. and Mag. Nat. Hist., Ser. 9, vol. xi, pps. 465-472.

1925. The Permian Fish Dorypterus. Trans. Roy. Soc. Edinburgh, LIII, Part III, (No. 31), pps. 97-661, 6 figs. 
Gregory, William K.

1913. Locomotive Adaptations in Fishes illustrating "Habitus" and "Heritage." Ann. N. Y. Acad. Sci., pp. 267-268.

1915. Present Status of the Problem of the Origin of the Tetrapoda, with Special Reference to the Skull and Paired Limbs. Ann. N. Y. Acad. Sci., vol. XXVI, pp. 317-383, Pl. IV.

GOODRICH, E. S.

1909. A Treatise on Zoology (Ed. E. Ray Lankester), Part IX, Vertebrata Craniata (First Fascicle: Cyclostomes and Fishes). 8vo. London.

Houssay, Frederic.

1909. Sur les conditions hydrodynamiques de la forme chez les poissons. C. R. Acad. Sci. Paris, 148, pp. 1076-1078. (Quoted in Bibliography of Fishes, Bashford Dean.)

1912. Forme, puissance et stabilité des poissons. Paris. 372 pps., 117 figs. (Quoted in Dean's Bibliography of Fishes.)

1914. The Effect of Water Pressure upon the Form of Fishes. (Scient. Amer., Suppl. 2032, pp. 376-378. 11 figs. Anonymous review of

JAEKEL, O. article of similar title by F. Houssay, La Science et la Vie, 1914.)

1909. Ueber die ältesten Gliedmassen von Tetrapoden. Sonder-Abdruck aus den Sitzungsberichten der Gesellschaft, Naturforschender Freunde, Nr. 10, Jahrgang 1909, pps. 587-615, 20 figs.

1909. Fischreste aus den Mamfe-Schiefern. Beiträge zur Geologie von Kamerun, Sonderabdruck aus den Abhandlungen der Konigl. Preuss. Geologischen Landesanstalt, Neue Folge, Heft 62, pps. 392-398, Taf. 1.

Jordan, D. S. AND Evermann, B. W.

1896-1898. The Fishes of North and Middle America. Bull. U. S. Nat. Mus., Vol. 47, Parts I, II, III, pps. 1-3313, 392 Pls.

KIAER, J.

1924. The Downtonian Fauna of Norway. I. Anaspida. Videnskapsselskapets-krifter I, Mat.-Naturv. Klasse, No. 6, pps. 1-139, Pls. 1-14.

Needham, James A. AND Lloyd, J. Y.

1916. The Life of Inland Waters. New York. 438 pp., 8 figs. (Quoted in Dean's Bibliography of Fishes.)

Nichols, J. T.

1915. On One or Two Common Structural Adaptations in Fishes. Copeia, July 27, No. 20, pps. 19-21.

OSBURN, R. C.

1906. The Origin of Vertebrate Limbs. Recent Evidence upon this Problem from Studies on Primitive Sharks. Ann. N. Y. Acad. Sci. Vol. XVII, Pt. II, pps. 1-21.

1906a. The Functions of the Fins of Fishes. Science, N. S. Vol. XXIII, pps. 585-587.

1907. Observations on the Origin of the Paired Limbs of Vertebrates. The Amer. Journ. Anat., Vol. VII, pps. 171-194, Pl. I-V. 
PANDER, C. H.

1858. Ueber die Ctenodipterinen des Devonischen Systems. 4to. St. Petersburg (Kais. Akad. d. Wiss.).

1860. Ueber die Saurodipterinen, Dendrodonten, Glyptolepiden des Devonischen Systems, Pls. 1-3. 4to. St. Petersburg.

PARSONS, H. DE B.

1888. The Displacements and the Area-curves of Fish. Trans. Amer. Soc. Mechanical Engineers, Vol. IX, pps. 1-17, 19 figs.

Patten, William.

1912. The Evolution of the Vertebrates and their Kin. Philadelphia. 486 pps., 309 figs.

Pettigrew, J. B.

1874. Animal Locomotion or Walking, Swimming and Flying, with a Dissertation on Aeronautics. Internat. Sci. Ser., No. 8, 264 pps., 130 figs.

REGAN, C. TATE.

1904. The Phylogeny of the Teleostomi. Ann. and Mag. Nat. Hist., Ser. 7, Vol. XIII, pps. 329-349, Pl. VII.

1906. A Classification of the Selachian Fishes. Proc. Zool. Soc. Lond., Oct. 10,1906 , pps. $722-758$, figs. 115-124.

1911. The Anatomy and Classification of the Teleostean Fishes of the Orders Berycomorphi and Xenoberyces. Ann. and Mag. Nat. Hist., Ser. 8, Vol. vii, pps. 1-9, Pl. I.

ROHON, J. V.

1892. Die obersilurische Fische von Oesel: Part I. Mem. Ac. St. Petersbourg, Vol. XXXVIII; Part II, ibid. Vol. XLI, 1893.

SCHLESINGER, G.

1909. Der sagittiforme Anpassungstypus nektonischer Fische. Verh. Zool.-Bot. Gesellschaft, Wien, 59, pps. 140-156, 7 figs.

1911. Die Locomotion der tänioformen Fische. Zool. Jahrb. (Abth. Syst.) 1911, 31, pps. 469-490.

1911a. Schwimmen und Schwimmtypen flinker Meeresfischen. Kosmos, 8 Jahrg., pps. 284-287.

1911b. Ueber undulatorische Bewegung bei Fischen. Verh. Zool.-Bot. Gesellschaft, Wien, 61, pps. 301-322, 6 figs.

Schmalhausen, J. J.

1912. Zur Morphologie der unpaaren Flossen. I. Die Entwicklung des Skelettes und der Muskulatur der unpaaren Flossen der Fische. Zeitschrift für wissenschaftliche Zoologie, Bd. C, Heft 3, pps. 509587, Taf. XV-XVIII.

1913. Zur Morphologie der unpaaren Flossen. II. Bau und Phylogenese der unpaaren Flossen und insbesonders der Schwanzflosse der Fische. Zeitschrift für wissenschaftliche Zoologie, Bd. CIV, Heft 1 , pps. 1-80, Taf. I, II.

SchmalhaUSEN, I.

1916. On the Functions of the Fins of the Fish. Revue Zoologique Russe. I. 
Sewertzov, A. N.

1916. Études sur l'évolution des Vertébrés inférieurs. 1. Morphologie du squelette et de la musculature de la tête des Cyclostomes. Archives Russes d'Anatomie, d'Histologie et d'Embryologie (Ed. A. Dogiel), Tome I, fascicule I, pps. 1-104, Pls. I-VI.

1923. Die Morphologie des Visceralapparates der Elasmobranchier. (Vorläuffige Mitteilung.) Anat. Anz. 56. Band, Nr. 17.

1923. The Place of the Cartilaginous Ganoids in the System and the Evolution of the Osteichthyes. Journ. Morphology, Vol. 38, No. 1 , pps. 105-145.

1924. The Development of the Dorsal Fin of Polypterus delhesi. Journ. Morphology, Vol. 38, No. 4. pps. 551-580.

STENSIÖ, ERIK A: SoN.

1927. The Downtonian and Devonian Vertebrates of Spitsbergen. Part I: Family Cephalaspidæ. A. Text. B. Plates. Skrifter om Svalbard og Nordishavet: Resultater av de Norske Statsunderstottede Spitsbergenekspeditioner, No. 12. Det Norske Videnskaps-Akademi I Oslo.

STRASSER, H.

1882. Zur Lehre von der Ortsbewegung der Fische durch Biegungen des Leibes und der unpaaren Flossen mit Berücksichtigung verwandter Locomotionsformen. Stuttgart, 1882, VI, 124 pps. 8 figs. (Quoted in Dean's Bibliography.)

1883. Ueber die Ortsbewegung der Fische. Jahresber. Schles. Ges. Vaterl. Cultur. Bresslau, 1883, 9, 147-150. (Quoted in Dean's Bibliography.)

TRAQUAIR, R. H.

1875. On the Structure and Systematic Position of the Genus Cheirolepis, Ann. Mag. Nat. Hist. (4) Vol. XV, pps. 237-249.

1877. The Ganoid Fishes of the British Carboniferous Formations. Part I. Palaeoniscidae. Monogr. Palaeontogr. Soc. Pls. I-VII.

1879. On the Structure and Affinities of the Platysomidae, Trans. Roy. Soc. Edinburgh, Vol. XXIX, pps. 343-391. Pls. III-VI.

1893. Palaeospondylus gunni. Proc. Roy. Phys. Soc. Edin., Vol. XII, pps. 87-94, Pl. I.

1898. On Thelodus pagei, Powrie, Sp. from the Old Red Sandstone of Forfarshire. Trans. Roy. Soc. Edin., vol. XXXIX.

1898a. Report on Fossil Fishes Collected by the Geological Survey of Scotland in the Silurian Rocks of the South of Scotland. Trans. Roy. Soc. Edin., Vol. XXXIX.

1905. Supplementary Report on Fossil Fishes Collected by the Geological Survey of Scotland in the Upper Silurian Rocks of Scotland. Trans. Roy. Soc. Edin., Vol. XL, pps. 879-888, Pls. I-III.

VOLKER, HEINRICH.

1911. Apparat zur Demonstration der Steuerbewegung der Fische. Monatsh. Nat. Unterr., 1911, 4; 157-158, 2 figs. 
WATSON, D. M. S.

1925. The Structure of Certain Palaeoniscids and the Relationships of that Group with other Bony Fish. Proc. Zool. Soc. Lond., No. LIV, pps. 815-870, Pls. I, II.

Winterstein, H.

1914. Handbuch der vergleichenden Physiologie, Vol. 3, Halfte 1, Theil. 1, pps. 1-248. Hena. Schwimmen der Fische, by Du Bois-Reymond, R.

WOODWARD, A. S.

1889-1901. Catalogue of the Fossil Fishes in the British Museum. 4 vols. London.

1890. The Fossil Fishes of the Hawkesbury Series. Mem. Geol. Surv. N. S. Wales, Vol. IV.

1906. On a Carboniferous Fish Fauna from the Mansfield District, Victoria. Mem. Nat. Mus. Melbourne, pps. 3-32, Pls. I-XI.

1915. The Use of Fossil Fishes in Stratigraphical Geology. Proc. Geol. Soc. Lond., Vol. LXXI, Part I, pps., 52-75.

1917. Notes on the Pycnodont Fishes. Geol. Mag., Decade VI, Vol. IV, No. 639, pp. 385-389.

1920. On certain Groups of Fossil Fishes. Proc. Linnean Soc. Lond., Session 132, pps. 25-34.

1921. Observations on some Extinct Elasmobranch Fishes. Proc. Linnean Soc. Lond., Session 133, pps. 29-39.

1922. Observations on Crossopterygian and Arthrodiran Fishes. Proc. Linnean Soc. Lond., Session 134, pps. 27-36. 


\section{$2 \mathrm{BHL}$ Biodiversity Heritage Library}

Gregory, William K. 1928. "Studies on the body-forms of fishes." Zoologica: scientific contributions of the New York Zoological Society 8(6), 325-421. https://doi.org/10.5962/p.203758.

View This Item Online: https://www.biodiversitylibrary.org/item/207688

DOI: https://doi.org/10.5962/p.203758

Permalink: https://www.biodiversitylibrary.org/partpdf/203758

\section{Holding Institution}

Smithsonian Libraries

\section{Sponsored by}

Biodiversity Heritage Library

\section{Copyright \& Reuse}

Copyright Status: In Copyright. Digitized with the permission of the rights holder

Rights Holder: Wildlife Conservation Society

License: http://creativecommons.org/licenses/by-nc/3.0/

Rights: https://www.biodiversitylibrary.org/permissions/

This document was created from content at the Biodiversity Heritage Library, the world's largest open access digital library for biodiversity literature and archives. Visit BHL at https://www.biodiversitylibrary.org. 